Omar Heriberto Santos Velascc

\title{
Núcleo Básico para um Servidor de \\ Nomes Baseado em Atributos
}

Dissertação apresentada ao Instituto de Ciências Matemáticas de São Carlos da Universidade de São Paulo como parte dos requisitos para obtenção do título de Mestre em Ciências - Área: Ciências da Computação e Matemática Computacional.

São Carlos

1993 
Omar Heriberto Santos Velasco

\section{Núcleo Básico para um Servidor de \\ Nomes Baseado em Atributos}

Dissertaçāo apresentada ao Instituto de Ciências Matemáticas de São Carlos da Universidade de São Paulo como parte dos requisitos para obtenção do título de Mestre em Ciências - Área: Ciências da Computação e Matemática Computacional.

Área de Concentração:

Sistemas Distribuídos e Programação Concorrente

Orientador:

Prof.Dr. Marcos José Santana

São Carlos

1993 
A mis padres, Olga y Heriberto, y a mi hermana Zenayda que representan la razón y él incentivo de este trabajo. Gracias por su amor, cariño, comprensión y sobre todo por su sacrificio. 
" O caminho do conhecimento é um caminho aberto a todos os homens, às pessoas comuns"

Paulo Coelho 


\section{Agradecimentos}

Ao professor e orientador Dr. Marcos José Santana pelas diretrizes seguras e permanente incentivo.

À Ana Claudia, pelo estímulo e incansável compreensão.

À FAPESP pelo auxílio financeiro concedido.

Aos meus amigos Claudia, Eduardo, Flávia, Guilherme, João, Luis Paulo, Marquinho, Pablo, Susete pelo companheirismo, apoio e incentivo.

Aos professores Nivaldi e Sandra pelo auxílio na definiçāo e implementaçāo do projeto e à Elisa pela valiosa colaboração.

Aos funcionários do LASD, Eduardo e José Luis, e a todos que direta ou indiretamente colaboraram na execução deste trabalho. 


\section{Sumário}

Lista de Tabelas

Lista de Figuras

Resumo

"Abstract"

Capítulo 1 - Introdução ...................... 001

Capítulo 2 - Redes Locais ...................... 004

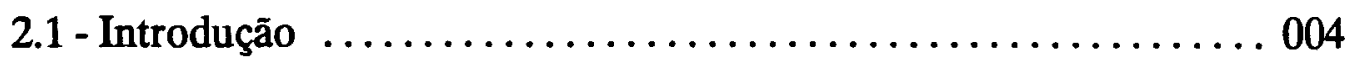

2.2 - Topologias ................................. 005

2.3 - Técnicas de Controle de Acesso ao Meio ................. 007

2.3.1 - Acesso em Estrela ........................... 009

2.3.2 - Acesso em Anel ............................... 009

2.3.3 - Acesso em Barramento ........................ 011

2.4 - Exemplos de Redes Locais Existentes ................. 012

2.4.1 - Rede Ethernet .......................... 012

2.4.2 - Token Ring ............................. 013

2.5 - Consideraçōes Finais ............................ 014

Capítulo 3 - Sistemas Computacionais Distribuídos ....... 015

3.1 - Introdução ................................. 015

3.2 - Caracterização de Sistemas Distribuídos ................ 016

3.2.1 - Modelos Arquiteturais ...................... 016

3.2.2 - Servidores Normalmente Presentes ................. 019 
3.2.3 - Vantagens e Desvantagens de Sistemas Distribuídos ...... 021

3.3 - Comunicação entre Processos ....................... 021

3.3.1 - Chamada de Procedimento Remoto (RPC) ........... 023

3.4 - Técnicas Utilizadas em Sistemas Distribuídos .............. 025

3.4.1 - Replicação ................................. 025

3.4.2 - Técnica "Cache Hints" ....................... 026

3.4 .3 - Técnica "Stashing" ........................... 026

3.4.4 - Memórias "Cache" .......................... 026

3.5 - Considerações Finais . .......................... 027

Capítulo 4 - Serviço de Nomeação e Servidores de Nomes para

Sistemas Computacionais Distribuídos ............. 029

4.1 - Introdução .................................... 029

4.2 - Servidores de Nomes ............................ 031

4.2.1 - Serviço Centralizado ......................... 031

4.2.2 - Serviço Distribuído ......................... 032

4.3 - Modelos Centralizado e Distribuído de Resolução de Nomes . . 036

4.3.1 - Comparação dos dois Modelos .................. 037

4.4 - Métodos para Gerenciamento de Nomes ................ 038

4.5 - Convençōes de Nomeação .......................... 040

4.5.1 - Nomeação Absoluta ........................... 041

4.5.2 - Nomeaçāo Relativa ........................... 042

4.6 - Exemplos de Servidores de Nomes e Serviços de Nomeação . . . 042

4.7 - Considerações Finais . .......................... 048

Capítulo 5 - Modelo de Nomeação Baseado em Atributos .... 050

5.1 - Introdução ................................ 050

5.2 - Modelo de Nomeação Baseado em Atributos ............ 051

5.2 .1 - Visão Estrutural ........................... 051

5.2 .2 - Visão Funcional ............................ 057

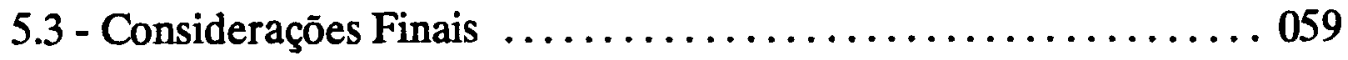


Capítulo 6 - Implementação do Núcleo Básico para um

Servidor de Nomes Baseado em Atributos ............ 061

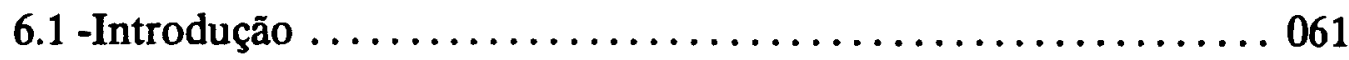

6.2 - Considerações do Projeto ........................ 063

6.3 - Funçōes do Núcleo Básico do SENA ..................... 063

6.3.1 - Acesso e Manipulação da Base de Dados ............. 064

6.3.2 - Interpretador .............................. 067

6.3.3 - Modelo de Nomeação Baseado em Atributos ........... 069

6.3.4 - Gerador de Atributos .......................... 074

6.3.5 - Comunicaçāo Cliente-Servidor ................... 078

6.3.6 - Interface Gráfica .......................... 083

6.4 - Consideraçōes Finais ........................... 083

Capítulo 7 - Conclusões ....................... 085

7.1 - Conclusōes e Contribuições do Trabalho ................. 085

7.2 - Proposta de Trabalhos Futuros .................... 088

7.3 - Crítica Bibliográfica ............................ 091

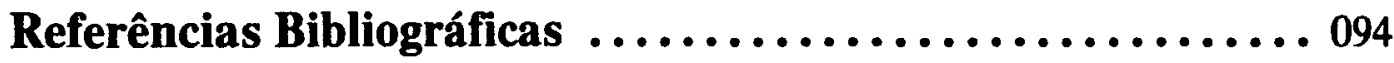

Bibliografia $\ldots \ldots \ldots \ldots \ldots \ldots \ldots \ldots \ldots \ldots \ldots \ldots \ldots \ldots \ldots, 100$

Apêndice A - Gramática LBA ................... 101

Apêndice B - Lista de Siglas .................... 106

Apêndice C - Glossário ....................... 108 


\section{Lista de Tabelas}

Tabela 3.1 - Modelo de Referência ISO-OSI $\ldots \ldots \ldots \ldots \ldots \ldots . \ldots 22$

Tabela 3.2 - Protocolos RPC ......................... 24

Tabela 6.1 - Funções Básicas do SENA .................. 73

\section{Lista de Figuras}

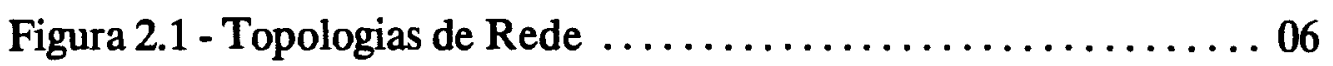

Figura 3.1 - Modelo Estação de Trabalho/Servidor ............. 17

Figura 3.2 - Modelo Banco de Processadores ................ 18

Figura 3.3 - Modelo Híbrido ......................... 19

Figura 4.1 - Nomes Externos e Id. Únicos ................. 35

Figura 4.2 - Tabela de Prefixos $\ldots \ldots \ldots \ldots \ldots \ldots \ldots \ldots \ldots \ldots . \ldots . \ldots . \ldots . \ldots$

Figura 4.3 - Convenções de Nomeação ................... 41

Figura 5.1 - Servidor Univers ........................ 60

Figura 6.1 - Nome Baseado em Atributos .................. 66

Figura 6.2 - Lista de Objetos ........................ 66

Figura 6.3 - Gerador de Atributos ...................... 74

Figura 6.4 - Fluxo de Dados no SENA ................... 75

Figura 6.5 - Modelo Cliente-Servidor . . . . . . . . . . . . . . . . 79

Figura 6.6 - Seqüência de Requisição .................... 80

Figura 7.1 - Segurança e Comunicação ................... 89

Figura 7.2 - Serviços de Alto Nível $\ldots \ldots \ldots \ldots \ldots \ldots \ldots \ldots \ldots . .60$ 


\section{Resumo}

O projeto e a implementação de Servidores de Nomes constituem fases importantes na construçāo de Sistemas Computacionais Distribuídos, pois esses módulos são encarregados de armazenar e fornecer informaçōes para todo o sistema, garantindo seu funcionamento correto e seguro.

Este trabalho apresenta um estudo detalhado sobre o serviço de nomeação, discutindo a maneira como é oferecido através dos servidores de nomes presentes na maioria dos ambientes computacionais distribuídos baseados em rede local. Enfase especial é dada à descrição da estrutura e detalhes de implementação do "SENA" (SErvidor de Nomes baseado em Atributos), o qual se baseia no Paradigma de Nomeação Baseado em Atributos.

Essa abordagem, adicionada ao ambiente de implementação, possibilita a obtenção de um servidor de nomes abrangente, que permite o gerenciamento de espaços de nomes em ambientes computacionais heterogêneos, sendo também capaz de atender solicitaçōes tanto de outros módulos do sistema distribuído, como de usuários, através de um conjunto de funçōes, a partir das quais novas funções podem ser criadas pelos próprios usuários.

As características apresentadas pelo SENA, levam à conclusão de que servidores de nomes baseados em atributos constituem uma alternativa extremamente atrativa na integração de espaços de nomes independentes, permitindo também a participação dos usuários na criação de serviços de nomeação personalizados. Portanto, um servidor de nomes baseado em atributos constitue um núcleo básico sobre o qual serviços de nomeação especializados podem ser construídos. 


\section{"Abstract"}

The design and implementation of name servers are fundamental stages in the construction of Distributed Computing Systems, because they store and provide information in order to guarantee correct and safe execution of the system.

This MSc dissertation shows a detailed study of naming service and the way it is offerred by name servers adopted in LAN-based distributed environments. Special emphasis is given on the description of the development of "SENA" (an Attributed-based Name SErver), that follows the Attributed-Based Naming Paradigm.

This approach yields a flexible name server, that allows a heterogeneous name space management, able to attend requests received either from other modules of the distributed system, or from users, always by means of the server basic functions or even new functions created from the basic ones.

The characteristics presented by SENA show that an attributed-based name server is an attractive alternative for the integration of independent name spaces; they also allow the system users to build customized naming services. Therefore an attributed-based name server builds a kernel over which new specialized naming services can be implemented. 


\section{Capítulo 1}

\section{Introdução}

A evolução da tecnologia computacional nas chamadas quatro gerações pode ser caracterizada pelas diferentes abordagens com que os computadores foram utilizados pelos usuários.

Assim na primeira geração (1945-1955), os programadores tinham o computador todo dedicado a eles enquanto o usavam. Na segunda geração (1955-1965), apareceu o processamento em lote ("batch"), onde os programadores tinham que submeter seus "jobs" (programa ou conjunto de programas) a uma fila de processamento. Esses programas eram executados um de cada vez e seus usuários retiravam os resultados após um certo tempo. Os sistemas de tempo compartilhado da terceira geração (1965-1980), compreendem a solução encontrada para que vários usuários compartilhem um computador, sob a ilusão de que cada um tem o computador só para si. A quarta geração (1980-1990) é caracterizada pelos computadores pessoais, onde os usuários têm sua própria máquina dedicada, no seu próprio escritório [TAN87, TAN92].

Durante meados da década de 80, surgiram pesquisas e desenvolvimentos, marcando o crescimento de sistemas com computadores pessoais executando sistemas operacionais de rede e sistemas operacionais distribuídos. Nos sistemas operacionais de rede, os usuários são conscientes da existência de múltiplos computadores e conseguem manipular máquinas remotas, copiar arquivos de uma máquina a outra, mas tudo explicitamente. Cada máquina executa um sistema operacional local e tem seus usuários proprietários. 
Já um sistema operacional distribuído é visto por seus usuários como um sistema monoprocessador tradicional, embora opere em múltiplos processadores. Em um sistema distribuído, os usuários não devem estar conscientes de onde seus programas estão sendo executados ou onde seus arquivos são armazenados; ele não faz distinção entre operações locais, ou remotas, sendo automaticamente e eficientemente manipulado pelo sistema operacional distribuído [TAN87, TAN92].

Sistemas computacionais distribuídos são projetados para permitir que computadores individuais compartilhem os recursos disponíveis em uma rede, fornecendo facilidades computacionais tão flexíveis quanto as tradicionais [TAN85, COU88, MUL89, TAN92].

As características citadas mostram um sistema mais poderoso e abrangente do que os convencionais. Os sistemas distribuídos são mais confiáveis, pois suas funções podem ser replicadas várias vezes, por exemplo, um arquivo pode ser armazenado em vários discos. Podem ser muito poderosos, já que várias computações podem ser feitas em paralelo.

Em geral, os sistemas operacionais distribuídos manipulam objetos, tais como arquivos, diretórios, "mailboxes", processos, serviços, usuários, nós, dispositivos de E/S, etc. Quando um usuário ou processo quer utilizar esses objetos, deve apresentar algum tipo de nome ao sistema operacional para especificar qual objeto deseja. $O$ sistema operacional deve verificar a permissão de acesso ao objeto e então fornecer ou não o endereço do objeto ao usuário ou processo. A manipulação pode incluir a inserção ou remoção de objetos, ou simples consultas sobre informações dos objetos existentes. Esse serviço é conhecido como serviço de nomeação e dentro de um sistema distribuído é normalmente fornecido pelo servidor de nomes.

Os servidores de nomes podem se tornar elementos fundamentais em um sistema distribuído, dependendo da carga de trabalho à qual é submetido. Dessa maneira, deve-se exigir desses servidores alta confiabilidade, alto desempenho e tolerância a falhas.

Nesta dissertação é discutida uma abordagem relativamente recente para o conceito de servidores de nomes, originada no modelo de nomeação baseado em atributos, que surge como uma alternativa moderna nas pesquisas de serviços de nomeação em sistemas computacionais distribuídos baseados em rede local.

Este trabalho tem como finalidade, introduzir os conceitos básicos do modelo proposto por Bowman, em [BOW90], e descrever a implementação de um servidor de nomes 
baseado em atributos, o qual deverá auxiliar futuras pesquisas em serviços de nomeação.

Esta dissertação está organizada em sete capítulos.

O segundo capítulo introduz os conceitos e as estruturas básicas características das redes locais de computadores, discutindo técnicas de controle de acesso ao meio, topologias clássicas e finalizando com a exposição de exemplos de implementação de redes locais.

O capítulo três aborda as características básicas de sistemas distribuídos, seus modelos arquiteturais, protocolos de comunicação, o paradigma do cliente/servidor, os principais servidores presentes nesses ambientes e algumas técnicas para construção de sistemas distribuídos.

O capítulo quatro enfatiza as funçōes básicas e as principais propostas para um servidor de nomes. Discutem-se as variações de implementação de um servidor desse tipo, suas vantagens e desvantagens. $O$ capítulo conclui apresentando exemplos de servidores de nomes implementados e em uso na atualidade.

No quinto capitulo, apresenta-se o modelo de nomeação baseado em atributos, o qual é abordado a partir de duas perspectivas organizacionais: do ponto de vista estrutural, onde são analisadas suas estruturas básicas e do ponto de vista funcional, que descreve as funçōes dos módulos nos quais esse modelo está dividido.

A implementação de um núcleo básico para um servidor de nomes baseado em atributos é descrita pormenorizadamente no capítulo seis.

No sétimo capítulo são apresentadas as conclusões, contribuições e sugestōes de trabalhos futuros, com o objetivo de complementar e melhorar o sistema desenvolvido e finalmente apresenta-se a crítica bibliográfica. 


\section{Capítulo 2}

\section{Redes Locais}

Este capítulo discute tópicos relevantes sobre redes locais, estando organizado em três seções principais, abrangendo: topologias existentes, técnicas de controle de acesso ao meio e exemplos de redes locais existentes.

\subsection{Introdução}

À medida que aumenta o número de sistemas computacionais em um único lugar, como por exemplo em um prédio de escritórios, em uma indústria, ou em um centro de operações, começa a ser atrativa a idéia de se interconectar esses sistemas, por várias razōes, destacando-se: o compartilhamento de recursos de alto custo e a possibilidade de compartilhamento de dados entre os sistemas [STA84a,MOU86].

Uma rede local é uma rede de comunicações que fornece a interconexão de dispositivos de comunicação de dados, limitados a um espaço geográfico [CLA78, STA84a].

Uma rede local é composta de três elementos básicos de hardware: um meio de transmissão, freqüentemente um cabo de par trançado, cabo coaxial ou fibras óticas; um mecanismo de controle para acesso ao meio; e uma interface de rede para os dispositivos de comunicação ou nós. É necessário ainda outro elemento que é um conjunto de protocolos implementados em software, os quais controlam a transmissão de informação de um nó a outro [CLA78]. 


\subsection{Topologias}

A topologia de uma rede corresponde à estrutura de interconexão física dos vários nós da rede, definindo assim um padrão de interconexão. A interconexão é definida pelo meio físico de transmissão, podendo refletir tanto a localização geográfica dos nós como o fluxo de informação gerado neles [CLA78, GIO86].

Tanenbaum, em [TAN89], apresenta dois tipos básicos de interconexão para a comunicação entre nós de uma rede:

Canal ponto-a-ponto: os nós da rede são conectados às interfaces, interligadas aos pares por meios físicos. Se um nó recebe uma mensagem que não lhe é destinada, a sua interface a retransmite. As mensagens destinadas à estação são copiadas e podem ou não ser retransmitidas, dependendo da topologia.

Canal de difusâo: neste caso o meio de comunicação é compartilhado por todos os nós. Dessa forma uma mensagem enviada por uma estação é recebida por todas as outras. A interface que recebe uma mensagem não destinada à estação respectiva, a ignora, caso contrário a mensagem é copiada em um "buffer" na estação.

Podem-se identificar três topologias básicas: estrela, anel e barramento.

\section{Topologia em Estrela [CLA78, STA84a, STA84b, GIO86,TAN89]}

Neste caso, tem-se um único elemento central de comunicaçāo ao qual estão ligados fisicamente todos os outros nós da rede, apresentando canais ponto-a-ponto. Fica sob responsabilidade do elemento central as decisões de roteamento para dessa forma estabelecer caminhos para a comunicação dos nós. Esta topologia adapta-se bem às situações onde o fluxo de comunicação é centralizado, mas a dependência de um nó centralizado pode ser uma séria desvantagem tanto em termo de desempenho como de confiabilidade (Figura 2.1a). 


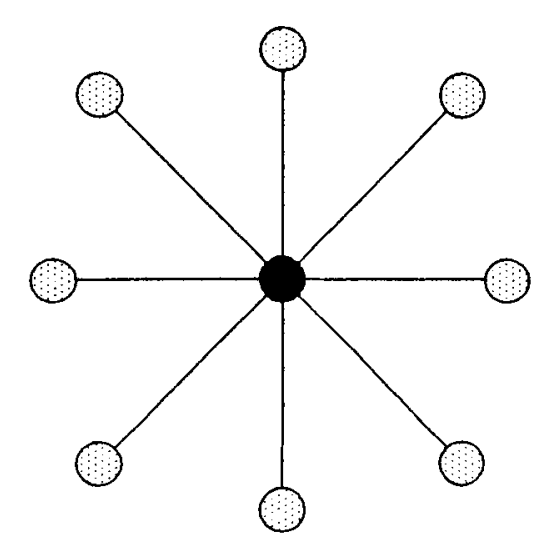

(a) Estrela

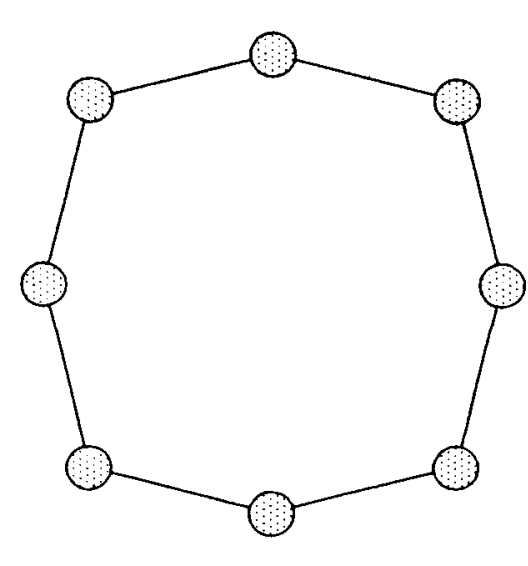

(b) Anel

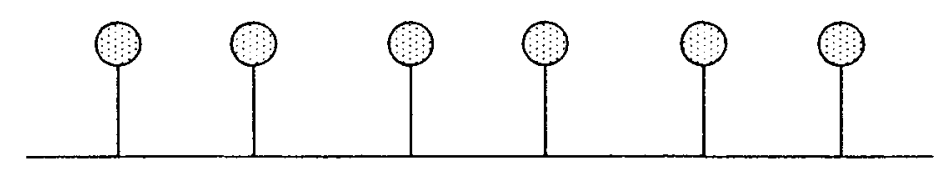

(c) Barramento

Figura 2.1 - Topologias de Rede

\section{Topologia em Anel [CLA78, STA84a, STA84b, GIO86, TAN89]}

O meio físico de transmissão, na topologia em anel, é comum a todos os nós de comunicação, sendo constituído por vários segmentos de transmissão ponto-a-ponto, unidirecionais, entre pares de nós de comunicação adjacentes. Nessa topologia, as mensagens são passadas seqüencialmente ao redor do anel, de uma interface a outra. A mensagem é analisada pela interface e copiada se estiver endereçada para ela. Normalmente, a mensagem copiada volta a circular no anel até retornar à sua interface original, onde será retirada (Figura 2.1b).

$\mathrm{Na}$ topologia em anel, não há necessidade de decisōes de roteamento [CLA78, GIO86]. Por outro lado, a participação de nós intermediários como repetidores, permite um maior alcance da rede. Mas, o fato de cada nó participar do processo de transmissão coloca a confiabilidade da rede na dependência da confiabilidade individual dos nós repetidores. Nesse caso, uma solução é proposta para esse problema, chamada de anel "star- shaped" 
[TAN89,COM91], cuja idéia $e$ ter um fio central onde as interfaces das estaçōes estão ligadas por dois fios. $O$ fio central não $\epsilon$ mais do que um outro anel, geralmente com sentido de transmissão reverso, que mantém um relê nas ligações com as interfaces. $O$ anel central age como elemento chaveador, podendo isolar um nó que apresente falhas, mantendo assim a topologia de anel em operação.

\section{Topologia em Barramento [STA84a, STA84b, GIO86, TAN89]}

A topologia em barramento tem um único canal de difusão que é compartilhado por todos os nós da rede. A mensagem enviada por uma estação é recebida por todas as outras, mas só é copiada na estação à qual é endereçada (Figura 2.1c).

$\mathrm{Na}$ topologia em barramento, é necessário um mecanismo que resolva conflitos quando duas ou mais estações desejam transmitir simultaneamente. Esse mecanismo pode ser centralizado ou distribuído [TAN89].

Os nós de comunicação intermediários têm geralmente um comportamento passivo no processo de transmissão das mensagens. Essa característica constitui uma vantagem em termos de confiabilidade, mas tende a limitar $o$ alcance da rede.

\subsection{Técnicas de Controle de Acesso ao Meio}

As redes locais caracterizam-se pelo uso de um único meio físico de transmissão, interconectando os nós de comunicação. As topologias em anel e em barramento permitem a difusão de mensagens entre as estações, eliminando a necessidade de roteamento intermediário. Assim, é necessário um mecanismo para controlar o acesso ao meio de transmissão de maneira que duas estaçōes possam trocar informação [STA84a, GIO86].

$O$ mecanismo que controla o acesso dos nós ao meio de transmissão compartilhado determina, por exemplo, qual estação está habilitada a transmitir num determinado instante de tempo. 


\section{Classificação das Técnicas de Controle de Acesso [STA84b, GIO86,}

\section{TAN89]}

Esta classificação pode ser baseada a partir das técnicas de multiplexação utilizadas. A multiplexaçāo é um procedimento básico de compartilhamento de um suporte físico de transmissão por vários sinais elétricos [GIO86]. Estas técnicas podem ser classificadas da seguinte maneira:

\section{Multiplexação por Divisão de Freqũência (FDM)}

Se existem $\mathbf{N}$ usuários, a largura de banda (capacidade do meio de transmissão) é dividida em $\mathbf{N}$ partes iguais, de maneira a separar os sinais em diferentes faixas de freqüência do meio físico de transmissão. Desde que cada usuário tem sua freqüência de banda própria, não existe interferência entre os diversos usuários.

Esta técnica de alocação estática do canal se mostra ineficiente quando o número de estações é grande e varia continuamente [TAN89].

\section{Multiplexação por Divisão no Tempo (TDM)}

Esta técnica caracteriza-se pela divisão do tempo de utilização do meio físico de transmissão entre os nós da rede, podendo seguir dois modos básicos: síncrono e assíncrono:

\section{Multiplexação por Divisão no Tempo Síncrona (STDM)}

Os intervalos de tempo alocados aos nós da rede são determinados a partir de um sinal padrão de sincronismo, presente periodicamente no meio físico [GIO86].

\section{Multiplexação por Divisão no Tempo Assíncrona (ATDM)}

O tempo de utilizaçāo do meio físico é dividido dinamicamente entre os diversos nós de comunicação, sob demanda, ou seja, segundo o tráfego de mensagens gerado entre eles 
[GIO86]. A alocaçāo dinámica sob demanda deve ser determinada mediante estratégias de controle centralizado ou distribuído.

No mecanismo centralizado, as funçōes de gerenciamento e controle de acesso ao meio sāo centralizados num único nó. Enquanto no mecanismo distribuído, essas funçōes são colocadas em todos os nós da rede.

\subsubsection{Acesso em Estrela [CLA78]}

A tarefa de controlar acesso ao meio de transmissão é simples na topologia em estrela. Nesse caso o nó central pode ter capacidade suficiente para manipular simultaneamente as mensagens de cada nó, ou pode fazer uma varredura de todos os nós, para determinar qual nó deve usar o meio de transmissão em um determinado instante.

\subsubsection{Acesso em Anel [STA84a, STA84b, GI086, MOU86, TAN89]}

As principais técnicas de controle de acesso ao meio de transmissão em anel são apresentadas a seguir.

\section{Passagem de Permissão ("token")}

Esta técnica é baseada na existência de uma entidade única ("token") que regula a inserçāo de mensagem no anel. Quando uma estação quer transmitir, deve esperar a passagem do "token" livre, alterar seu estado para ocupado e dessa maneira adquirir o direito "exclusivo" de transmissão. Quando terminar a transmissão, a estação transmissora retorna o "token" para o estado livre, e o recoloca no anel.

Nesta técnica, observam-se importantes implicações no desempenho da comunicação: uma mensagem tem seu tamanho variável e limitado pelo tempo de posse do "token", sendo permitido limitar o tempo máximo de espera para acesso ao meio. 
Por outro lado, é necessário uma estação monitora para resolver situações como a perda do "token" ou a ocorrência de "token" continuamente ocupado.

\section{Quadro Vazio ("Empty Slot")}

A técnica de controle de acesso chamada quadro vazio, é baseada na existência de um número fixo de quadros vazios ("slots") de tamanho fixo que circulam permanentemente no anel. Cada quadro possui no cabeçalho um bit de informação indicando se o quadro está cheio ou vazio. Uma estação querendo transmitir deve esperar a chegada de um quadro vazio, marcá-lo como ocupado e colocar a mensagem à medida que o quadro passa.

Depois de uma volta no anel, o quadro ocupado volta à estação transmissora, que o marca como vazio. E a estação poderá transmitir um novo pacote.

Esta técnica permite transmitir mensagens de tamanho fixo e o acesso ao meio de transmissão pode ser simultâneo para as estaçōes.

\section{Inserçāo de Registro}

Esta técnica baseia-se na existência de dois registradores de deslocamento em cada nó do anel. Uma estação que deseja transmitir, coloca a mensagem em um registrador de deslocamento chamado de transmissão. A inserção do registrador $\varepsilon$ permitida quando o anel está livre ou entre duas mensagens circulando no anel. As mensagens que chegam em uma estação, no instante em que esta se encontra inserindo um registro, são armazenadas em um outro registrador de recepção, e serão remitidas em circulação quando a estação finalizar a inserção do seu registro.

Uma estação estará novamente habilitada para transmitir quando não existam mensagens no anel, quando não existam mensagens armazenadas no seu registrador de recepção, ou até que uma mensagem transmitida retorne ao seu registrador.

Nesta técnica obtem-se a máxima utilizaçāo do anel através do acesso simultâneo ao meio, as mensagens são de tamanho variável, porém os procedimentos envolvidos são bastante complexos. 


\subsubsection{Acesso em Barramento [STA84a, STA84b, GI086, TAN89]}

Neste caso, as principais técnicas de controle de acesso ao meio de transmissão são CSMA/CD e passagem de permissão ("token"). A técnica utilizada com maior freqüência é a CSMA/CD, que é uma extensão de CSMA.

\section{CSMA (Carrier Sense Multiple Access)}

Nesta técnica, uma estação querendo transmitir escuta o meio de transmissão para determinar se outra transmissão está ocorrendo. Se o meio estiver livre a estação transmite, caso contrário, espera algum tempo e tenta transmitir novamente, utilizando um dos três algoritmos persistentes:

-Não-persistente: a estação espera um período de tempo aleatório para então escutar o meio novamente;

-1-persistente: a estação continua a escutar o meio até ele ficar livre e então transmite;

-P-persistente: a estação continua a escutar o meio até ele ficar livre e então transmite com uma probabilidade pré-estabelecida p, ou adia a transmissão com uma probabilidade (1-p).

O algoritmo não persistente tenta limitar as colisōes, dado o tempo de espera ser aleatório, mas o canal poderá ficar ocioso por um período de tempo.

$O$ algoritmo 1-persistente evita que o meio fique desocupado, por outro lado é mais propenso a colisōes. $O$ algoritmo p-persistente tenta reduzir o número de colisões e tornar mínimo o tempo que o meio fica ocioso.

\section{CSMA/CD (Carrier Sense Multiple Access with Collision Detection)}

Esta técnica introduz a deteçâo de colisões imediatamente após sua ocorrência e mantém as características principais da técnica CSMA, adicionando algumas regras: 
1.Se uma colisão é detectada durante a transmissão, cessa-se imediatamente a transmissão da mensagem e é emitido um sinal padrão para alertar todas as estações sobre a colisão;

2.Depois de transmitido o sinal, retarda-se a tentativa de transmissão de acordo com uma distribuição aleatória de atrasos; então tenta-se transmitir utilizando CSMA.

\section{Passagem de permissão ("token") em barramento}

Esta técnica segue essencialmente os mesmos princípios da técnica de passagem de permissão em anel. Na topologia em barramento é necessário implementar um mecanismo que ordene as estaçōes, formando um anel lógico. Cada estação participante do anel lógico tem armazenado o endereço do seu nó predecessor, do qual recebe o "token", e o endereço do seu nó sucessor para o qual envia o "token".

Quando uma estação recebe o "token", ela adquire o controle do barramento por um tempo determinado.

Nesse esquema é necessário tratar algumas situaçōes como inserção e remoção de estaçōes do anel, ruptura do anel e outros.

\subsection{Exemplos de Redes Locais Existentes}

\subsubsection{Rede Ethernet [SMO85, GIO86, COU88, TAN89, COM91]}

O sistema Ethernet foi desenvolvido pelo Centro de Pesquisas da Xerox em Palo Alto no ano de 1972 [SMO85]. Desde então, várias organizações têm desenvolvido e construído redes locais baseadas na Ethernet. Mais recentemente, em 1978, a Xerox, a DEC ("Digital Equipment Corporation") e a Intel, atualizaram cooperativamente o projeto Ethernet, tornando-o base para o padrão IEEE 802.3 [COM91].

A Ethernet padrão (IEEE 802.3) é projetada com a técnica de controle de acesso ao meio CSMA/CD 1-persistente [TAN89]. 
As principais características da rede Ethernet são:

-Taxa de Transmissão de 10 Mbps (10 milhões de bits por segundo)

-Tamanho máximo da rede: $2,5 \mathrm{Km}$ (entre as estaçōes mais extremas)

-Tamanho máximo de um segmento da rede: $500 \mathrm{~m}$. Para estender a rede é necessário instalar repetidores a cada $500 \mathrm{~m}$.

-Meio de transmissão: cabo coaxial de 0.5 polegada de diâmetro de 50 ohms.

-Sistema de codificaçāo do sinal: " Manchester Encoding ". Sinal de alta é + 0.85 volts e o de baixa é -0.85 volts

-Tamanho do campo de endereçamento: 6 bytes

-Configuração usual da Ethernet $e$ :

-"Transceiver": $\hat{e}$ um equipamento eletrônico que detecta transmissões e colisōes no meio. A distância máxima entre dois "transceivers" é de $2.5 \mathrm{Km}$ e nenhum caminho entre eles pode atravessar mais de 4 repetidores.

-Cabo do "transceiver": conecta o "transceiver" à placa de interface no computador. Seu tamanho máximo e 50 metros.

-Placa de interface: contém o "chip" controlador que transmite e recebe mensagens do "transceiver".

-Esta rede apresenta baixa eficiência a altas cargas de trabalho [TAN89].

\subsection{2 "Token Ring" [BUX85, GIO86, COU88, TAN89, COM91]}

Essa arquitetura de rede é a escolhida pela IBM para suas redes locais e foi incluída pela IEEE no padrão 802, chamado de "Token Ring" (IEEE 802.5). A rede controla o acesso ao meio de transmissões através da passagem de permissão ou "token".

As principais características da Token Ring sāo: 
-Taxa de transmissão: $10 \mathrm{Mbps}$

-Sistema de codificaçāo do sinal: "Manchester Encoding", com voltagens de alto e baixa na magnitude absoluta de $4.5 \mathrm{~V}$ e $3.0 \mathrm{~V}$

-Tamanho do token: 3 bytes

-Tamanho do campo de endereçamento: 6 bytes

-Tempo máximo de permanência do "token": $10 \mathrm{msec}$

-Configuração usual:

-Interface do anel: opera em dois modos:

-escuta: os bits são copiados a um "buffer" interno e retransmitidos no anel

-transmissão: a interface quebra o anel permitindo a transmissão dos dados no anel. Os bits são removidos pela estaçāo transmissora

-Estaçāo monitora: detecta e resolve casos de erros:

-"Tokens" perdidos: nesse caso estabelece um "time-out" e se for necessário retransmite um novo "token"

-pacotes 6rfãos: retira o pacote e insere um "token" no anel

\subsection{Considerações Finais}

Redes locais surgem como soluçōes ao problema de interconexão e compartilhamento de recursos computacionais dispersos a nível local. Essa classe de redes pode fornecer alta confiabilidade através da implementaçāo de recursos alternativos, taxa de erros baixa e ainda mantém uma alta taxa de transmissão.

Cada uma das topologias apresentadas tem suas vantagens e desvantagens quanto à confiabilidade e ao custo/desempenho. A avaliação para escolha de uma dessas topologias depende do ambiente de aplicação e dos aspectos operacionais do sistema. Entre as técnicas de controle de acesso ao meio destacam-se as de controle de acesso aleatório, embora não ofereçam garantia determinística de acesso. 


\section{Capítulo 3}

\section{Sistemas Computacionais Distribuídos}

Este capítulo enfoca tópicos relacionados a Sistemas Distribuídos e está organizado em três seçōes principais, abrangendo: caracterização de sistemas distribuídos, protocolos de comunicação e técnicas para construção de sistemas distribuídos.

\subsection{Introdução}

Basicamente, um sistema computacional distribuído é composto por uma coleção de computadores autônomos interligados por uma rede de comunicação de topologia arbitrária (cujo hardware deve oferecer mecanismos de comunicação) e por um sistema operacional distribuído [KIR88, SIN91a], cujo conceito chave é a transparência, ou seja, o uso de múltiplos computadores deve ser invisível ao usuário [TAN85, COU88, MUL89, TAN92]. Vários autores consideram a tolerância a falhas como outro requisito indispensável para um sistema distribuído [KIR88, MUL89].

Duas classes principais de sistemas computacionais distribuídos são identificados, em [COU88]:

-Sistemas fracamente acoplados: compostos de computadores autônomos, cada um executando parte de um sistema operacional global e compartilhando recursos através da rede. 
-Sistemas fortemente acoplados: compostos de múltiplos processadores dentro de um sistema de hardware integrado, sob o controle de um único sistema operacional.

No decorrer deste trabalho serão considerados apenas sistemas computacionais distribuídos fracamente acoplados.

\subsection{Caracterização de Sistemas Distribuídos}

Têm sido sugeridos vários modelos de sistemas distriburdos, cada um deles com suas características arquiteturais próprias. Os serviços oferecidos por esses sistemas distribuídos são implementados como componentes de "software" separados e geralmente executados em diferentes computadores, chamados de computadores servidores [COU88]. Por outro lado, características previamente citadas de sistemas distribuídos fazem com que eles apresentem uma série de vantagens e desvantagens em relação aos sistemas centralizados.

\subsubsection{Modelos Arquiteturais}

A arquitetura de um sistema distribuído identifica os principais componentes e módulos de hardware e software do sistema, definindo o relacionamento entre eles [COU88]. Dependendo das características esperadas e dos objetivos do sistema, diversos recursos e organizaçōes podem ser adotados.

Vários modelos arquiteturais têm sido propostos destacando-se entre eles:

-Estação de trabalho/senvidor neste modelo cada usuário tem uma estação de trabalho pessoal para executar seus programas de aplicação. $O$ acesso aos recursos compartilhados é feito de uma maneira transparente, através de um software de comunicação. Um conjunto de servidores fornecem serviços específicos: servidor de arquivos, servidor de diretórios, servidor de impressão, servidor de nomes, etc [TAN85, COU88, TAN92] (Figura 3.1). 


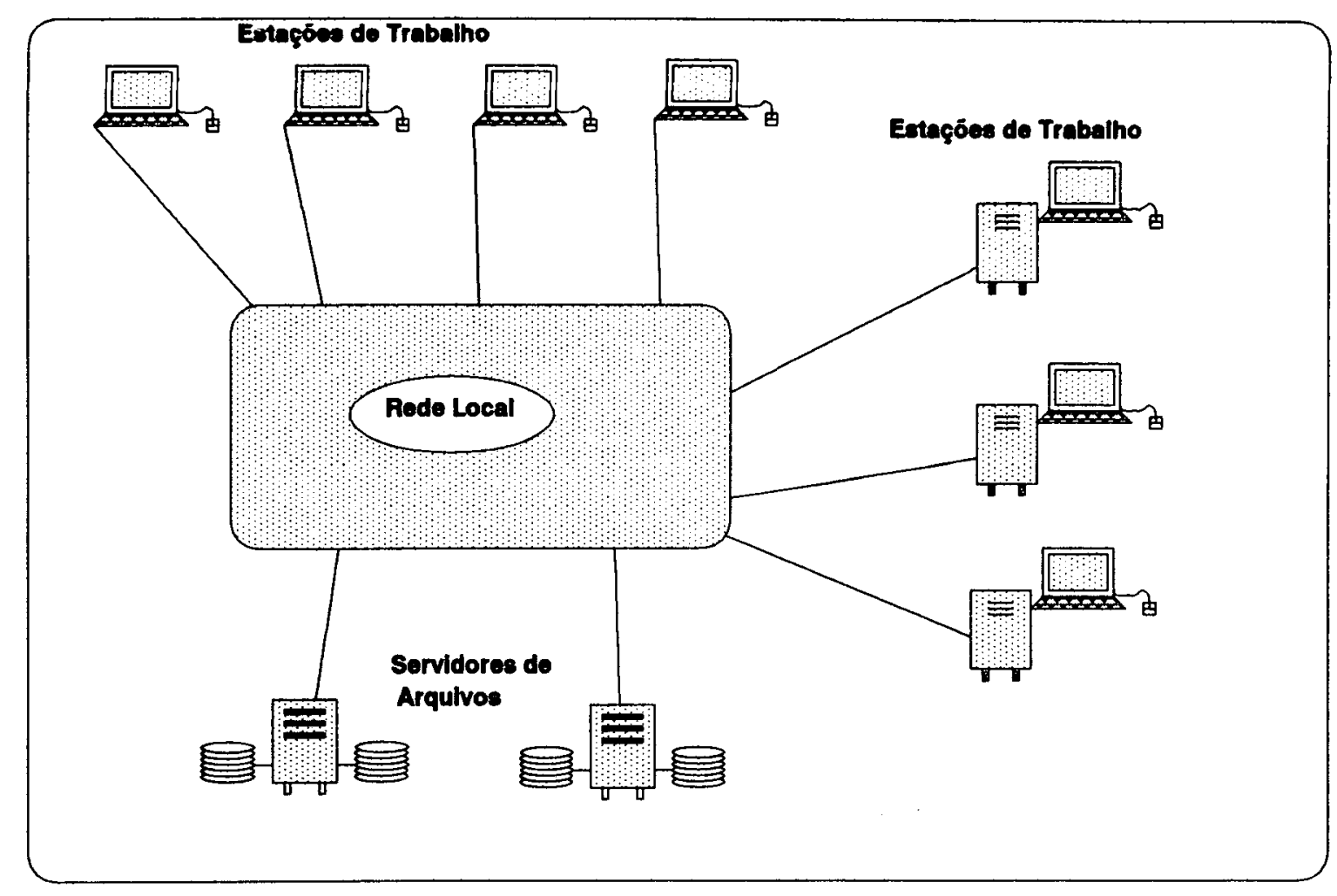

Figura 3.1 - Modelo Estação de Trabalho/Servidor

-Banco de processadores: este modelo caracteriza-se pela execução de programas em um conjunto de computadores gerenciado por um servidor de processamento. O usuário trabalha em um terminal ligado à rede e, sempre que precisa maior capacidade computacional, um ou mais processadores do banco lhe são atribuídos temporariamente. Ao finalizar o trabalho, os processadores são liberados e retornam ao banco. Este modelo também pode oferecer aos usuários diferentes arquiteturas de processadores [TAN85, COU88, TAN92] (Figura 3.2).

-Minicomputador: o sistema consiste de alguns minicomputadores, onde o usuário trabalha em uma máquina específica e através de um software de rede tem acesso remoto a outras máquinas do sistema [TAN85, COU88, TAN92].

-Híbrido: este modelo é baseado no modelo estação de trabalho/servidor, mas com a adição de um banco de processadores, que podem ser alocados dinamicamente para tarefas maiores do que as suportadas por estaçōes de trabalho ou tarefas que requeiram computação concorrente [COU88, TAN92] (Figura 3.3). 


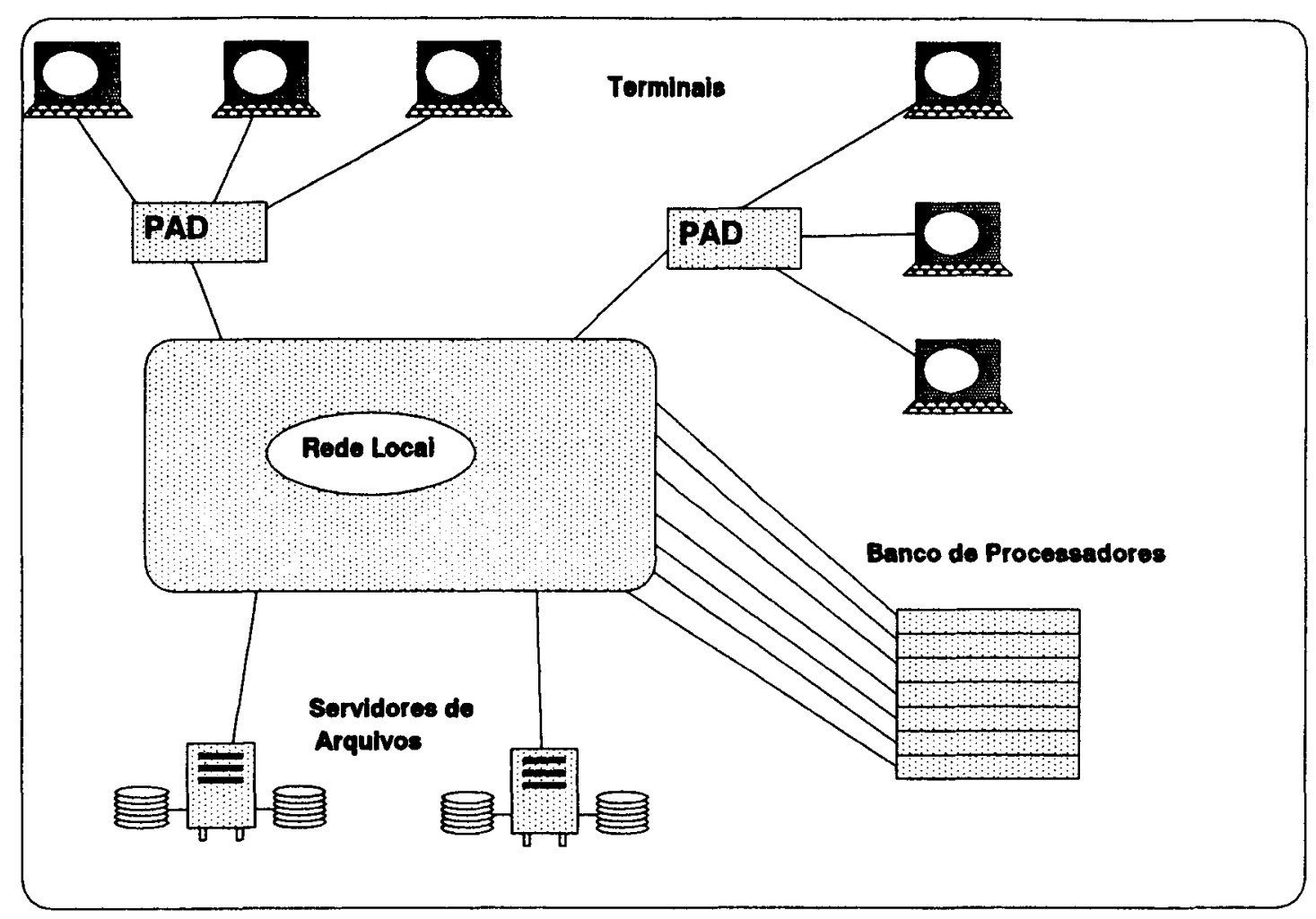

Figura 3.2 - Modelo Banco de Processadores

-Integrado: consiste na combinação de computadores monousuário e multiusuário interligados por uma rede heterogênea. Cada máquina é provida por software apropriado para realizar tanto o papel de servidor como também o de processador de aplicaçōes [COU88] .

A maioria dos sistemas distribuídos em uso são baseados no modelo estação de trabalho/servidor. As estaçōes de trabalho permitem a execução de programas de aplicação onde o bom desempenho da interface com o usuário é fundamental. $O$ modelo de banco de processadores apresenta vantagens quando a carga de processamento do usuário é muito grande, por outro lado, a interação com o usuário é comprometida pelo uso da rede. Dessa maneira aparece o modelo híbrido como o mais atrativo, pois oferece as principais vantagens dos modelos anteriores [COU88]. 


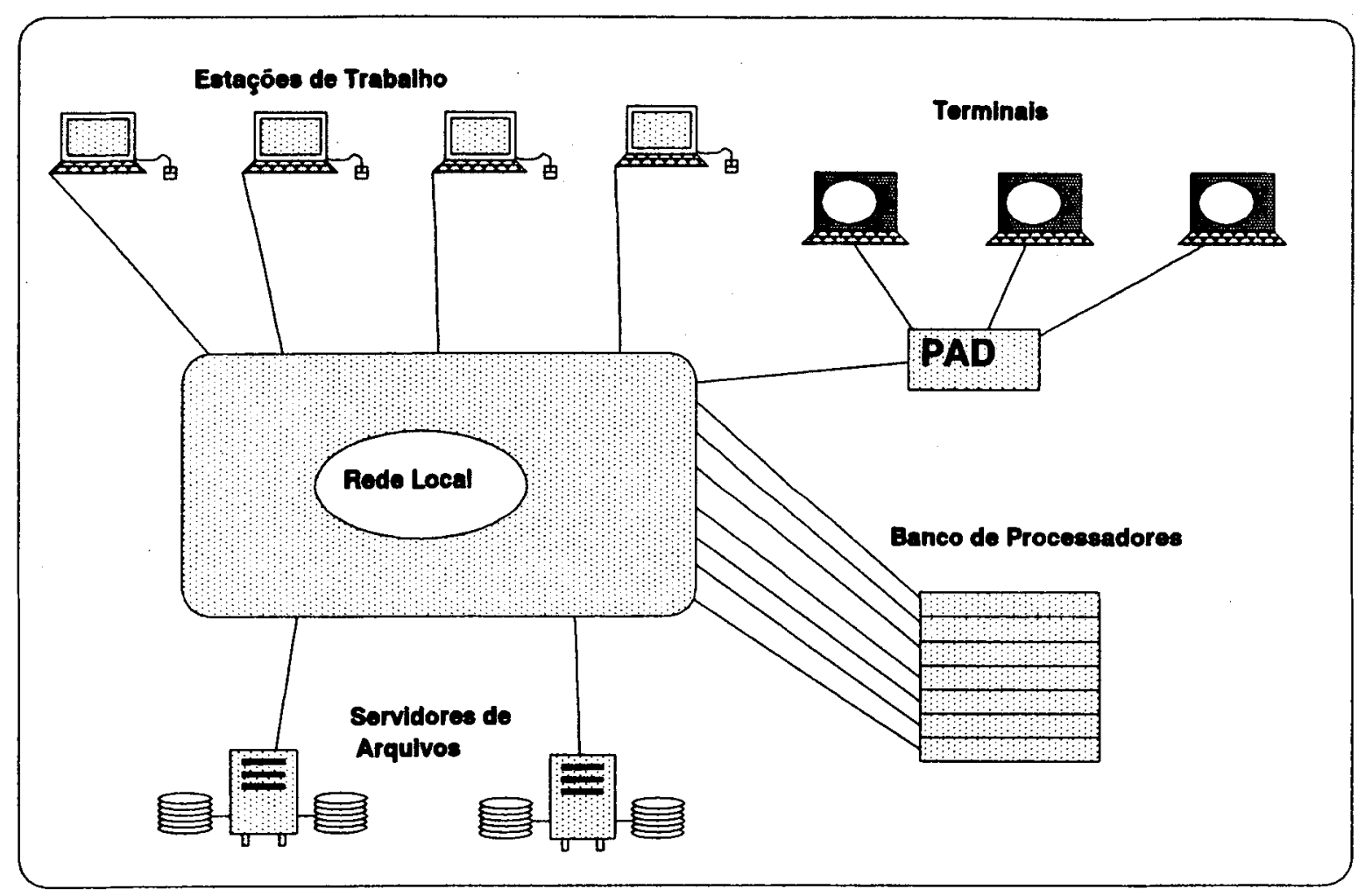

Figura 3.3 - Modelo Híbrido

\subsubsection{Servidores Normalmente Presentes}

Todos os modelos arquiteturais de sistemas distribuídos são baseados no uso de software modular [COU88], onde cada módulo constitui um dos vários serviços fornecidos por sistemas operacionais convencionais, implementados em sistemas distribuídos através de servidores remotos. $O$ uso desses servidores implica na redução do núcleo do sistema operacional, simplificando e permitindo a fácil adição de novos serviços ao sistema. Alguns exemplos de servidores normalmente presentes em sistemas distribuídos são:

-Servidor de arquivos: sua função é fornecer um local de armazenamento de arquivos confiável, que possa ser compartilhado pelos usuários do sistema. $\mathrm{O}$ servidor de arquivos deve ter seu proprio esquema de autorização e proteção para o acesso aos seus arquivos [LUN82, GIO86, COU88]. 
-Servidor de impressão: oferece aos usuários o serviço de impressão. Esse serviço pode ser implementado por pré-alocação (a impressora é alocada para um usuário por vez) e por "spooling" (os arquivos são enviados ao servidor, este os armazena em uma fila e imprime um de cada vez) [TAN85, GIO86].

-Senvidor de "boot" (ou servidor de carga): é o responsável por fornecer o sistema operacional às máquinas quando estas são ligadas; também auxilia na recuperação de falhas, através de revisão periódica do estado das máquinas [TAN85].

-Servidor de relógio: é o encarregado de organizar o serviço de tempo de duas maneiras: o cliente requisita a hora ou o servidor divulga a hora periodicamente. $O$ servidor organiza o serviço de maneira a sincronizar as máquinas do sistema levando em consideração o atraso na transmissão [TAN85].

-Servidor de correio eletrônico: permite que os usuários se comuniquem através de troca de mensagens utilizando a rede como meio de transmissão. Consiste basicamente em associar a cada usuário o endereço de uma caixa postal, onde serão depositadas as mensagens que lhe forem enviadas ou por ele enviadas [GIO86].

-Servidor de nomes: sua função é manter a correspondência entre os recursos e os endereços desses recursos no sistema, e mapear informaçōes sobre os recursos para endereços verificando os privilégios de quem quer ter acesso aos recursos. Dessa maneira assegura que os recursos do sistema sejam utilizados por usuários autorizados [TAN85].

-Servidor de Comunicação: quando um sistema distribuído precisa se comunicar com outros sistemas remotos, o serviço de comunicação converte as mensagens e protocolos do formato interno àquele esperado pelo carregador de pacotes da rede global [TAN85]. 


\subsubsection{Vantagens e Desvantagens dos Sistemas Distribuídos [MUL89]}

\section{Vantagens:}

-Flexibilidade: um módulo pode ser substituído, expandido, alterado ou retirado, sem afetar os demais.

-Modularidade: o sistema pode ser desenvolvido de forma gradual, acrescentando-se novos módulos quando necessário.

-Maior disponibilidade: a eventual falha de uma máquina não impede o funcionamento das demais.

-Alto grau de compartilhamento: recursos de custo elevado e informaçōes são compartilhados por um grande número de usuários.

-Maior confiabilidade: a replicação de informação em diferentes lugares aumenta a confiabilidade geral do sistema.

\section{Desvantagens:}

-Dificuldades de controle: gerenciar os recursos do sistema é mais difícil devido ao alto grau de compartilhamento, podendo surgir problemas de integridade, privacidade e segurança dos dados.

-Dependência da rede: a rede de comunicação impõe restriçōes de confiabilidade e desempenho ao sistema distribuído.

-Consistência: manter a consistência de informaçōes em vários lugares requer mecanismos de atualização eficientes.

\subsection{Comunicação entre processos}

Uma forma de comunicaçāo entre processos é feita através de passagem de mensagens, a qual é amplamente discutida pelo modelo de referência ISO-OSI 
("International Standard Organitation" - "Open System Interconnect"). Esse modelo é estruturado em sete camadas: camada física, camada de enlace de dados, camada de rede, camada de transporte, camada de sessão, camada de apresentação e camada de aplicação (Tabela 3.1). Usando-se este modelo é possível interligar computadores com sistemas operacionais distintos e códigos de caracteres diferentes [TAN85, MUL89, TAN92].

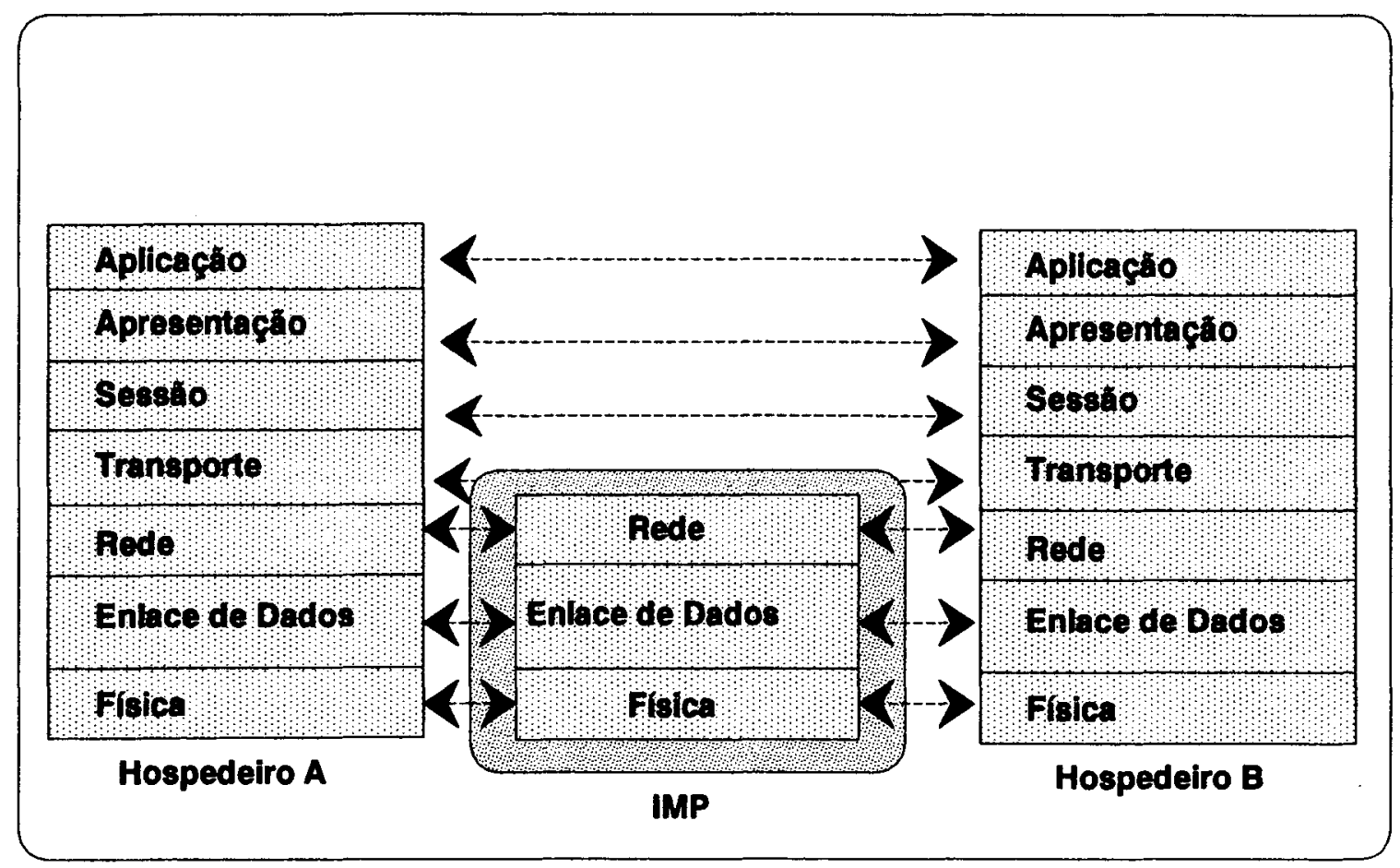

Tabela 3.1 - Modelo de Referência ISO-OSI

Devido à sobrecarga criada por essas sete camadas, os sistemas distribuídos experimentais têm optado por modelos mais simples, para construírem sistemas com passagem de mensagens, destacando- se a arquitetura cliente/servidor.

\section{Paradigma do cliente/servidor}

Um servidor é definido como qualquer processo que ofereça um serviço disponível através da rede. Um cliente é qualquer processo iniciado pelo usuário (ou em nome do usuário), que venha requerer os serviços de algum servidor. Dessa maneira, o servidor pode ser o cliente de um outro processo servidor [LUN82, TAN89, ASC91, COM91, COM93]. 
Nesses sistemas, o cliente envia o pedido para o servidor e espera uma resposta. Por sua vez, o servidor recebe pedidos, processa-os e retorna os resultados aos clientes requisitantes. Esse tipo de comunicação pode ser bloqueante (o processo cliente fica bloqueado até o servidor receber a mensagem ou enviar um reconhecimento ao cliente) ou não bloqueante (o cliente retorna o controle logo após transmitir e armazenar o pedido em um "buffer", permitindo a retransmissão em caso de falha) [TAN85, COU88, TAN92]. Um suporte possível para essa comunicação constitui as chamadas de procedimento remotos.

\subsubsection{Chamada de Procedimento Remoto (RPC)}

Uma chamada de procedimento remoto é uma extensão do conceito de chamada de procedimento comum, para ambientes distribuídos. Nesse caso o procedimento chamado $\varepsilon$ executado em um processo diferente e usualmente em um computador diferente daquele no qual o processo requisitante está sendo executado [TAN85, COU88, MUL89, ASC91, TAN92, COM93]. A chamada de procedimento remoto $e$ um tipo de comunicação bloqueante, que permite usar os serviços distribuídos no sistema, sem precisar conhecer seus endereços na rede. A localização dos serviços fica assim transparente para o cliente.

Os procedimentos encarregados de reconhecer as chamadas remotas são conhecidos como "stubs" ou "marshallings" [TAN85, COU88, MUL89, TAN92]. Estes procedimentos montam e enviam as mensagens do lado do cliente e as desmontam e fazem a chamada local do lado do servidor. Os "stubs" ou "marshallings" encapsulam todos os detalhes de conversão e comunicação entre processos [MUL89, ASC91].

Uma chamada de procedimento remoto finaliza se a mensagem de requisição de serviço do cliente chega ao servidor e a mensagem de resposta correspondente retorna com sucesso. Contudo, o sucesso nāo é garantido devido às possíveis perdas de mensagens ou a falhas dos computadores.

Couloris, em [COU88], identifica os possíveis problemas decorrentes de falhas no sistema, os quais podem ser evitados introduzindo "time-out's" (tempo máximo de espera por uma resposta a uma mensagem enviada). Assim, tem-se:

1)A mensagem de requisição é perdida. 
2)A mensagem de resposta é perdida.

3)O servidor falha e é reinicializado.

4)O cliente falha e é reinicializado.

A implementação do "time-out" para retransmitir uma requisição quando a correspondente resposta a uma requisição prévia nāo tiver chegado, depende de qual das seguintes semânticas é escolhida [COU88, TAN89, TAN92]:

1)Pelo menos uma vez: o cliente tenta repetidamente depois de vários "time-out's" até receber uma resposta ou poder informar que o servidor nāo está em operaçāo.

2)No máximo uma vez: se tudo for bem, o servidor executará uma única vez a requisição. Caso seja detectada uma falha no servidor, um código de erro é retornado ao cliente, $e$ as retransmissōes são suspensas.

3)Exatamente uma vez: garante a execução do procedimento no servidor uma única vez.

Os protocolos para intercâmbio de RPC's entre cliente e servidor são descritos na Tabela 3.2 [COU88].

\begin{tabular}{|l|l|l|l|}
\hline \multirow{2}{*}{ Nome } & \multicolumn{3}{|c|}{ Mensagens enviadas pelo } \\
\cline { 2 - 4 } & Cliente & Servidor & Cliente \\
\hline R & Requisiçáo & & \\
RR & Requisiçáa & Resposta & \\
& Requisiçáo & Resposta & Reconhecimento-Resposta \\
\hline
\end{tabular}

Tabela 3.2 - Protocolos RPC 


\subsection{Técnicas Utilizadas em Sistemas Distribuídos}

Várias técnicas têm sido propostas com objetivo de aumentar a confiabilidade, disponibilidade e desempenho de sistemas distribuídos. Esta seção tem como objetivo dar uma visão geral sobre técnicas de replicação, "hints", "stashing" e memórias cache.

\subsubsection{Replicação}

Manter uma única cópia de informaçōes sobre o sistema $e ́$ um procedimento muito arriscado, podendo comprometer o correto funcionamento do sistema. Uma maneira de

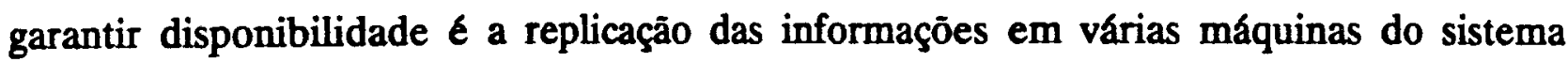
[LUN82, TAN85, MUL89].

Replicar informação imutável é uma tarefa trivial. A dificuldade surge nas informaçōes mutáveis e nos serviços monitorados através dos seus estados. Manter essa informação consistente requer algoritmos especiais e complexos [MUL89].

Coulouris, em [COU88], cita duas abordagens para replicar informaçōes contidas em arquivos:

-Estratégia mestre/escravo: nesta abordagem, um servidor principal mantém uma cópia mestre do arquivo e vários servidores secundários mantêm uma réplica do arquivo. Todos os serviços de atualização devem ser feitos no servidor principal, o qual informará as mudanças aos servidores secundários. Leituras dos arquivos podem ser feitas tanto no servidor principal como nos servidores secundários;

-Controle de atualização distribuido: esse controle pode ser feito a partir de algoritmos de votaçāo, onde a maioria que mantém réplicas de um arquivo, assegura que a versão mais recente está sempre disponível. A atualização é feita com base em regras de votação, da seguinte maneira: a requisição de atualização feita a um servidor é avaliada pelos servidores que mantêm réplicas do arquivo. Se a atualização $\epsilon$ aceita, cada servidor atualiza sua cópia. Caso contrário o cliente pode tentar de novo. 


\subsubsection{Técnica "Cache Hints"}

Hint é o resultado de uma operação remota, que é armazenado localmente e é usado sempre que essa operaçāo for requisitada. No caso de um "hint" estar errado ou obsoleto, isso será detectado quando for utilizado; nesse caso, o hint é invalidado, a operação refeita e novamente armazenada localmente [MUL89].

"Hints", é uma técnica fácil de ser utilizada que resulta em aumento de desempenho [MUL89,TER87].

\subsubsection{Técnica "Stashing"}

"Stashing" simplesmente consiste em manter cópias de informações chave para serem usadas quando as informações remotas não estão disponíveis. "Stashing" દ adequada para informações pequenas, sujeitas a poucas mudanças. Quando esta técnica é usada, é possível continuar trabalhando limitadamente, mesmo quando os serviços essenciais estejam fora do ar [MUL89].

As técnicas de "Cache Hints" e "Stashing" são normalmente usadas para manter informaçōes de nomeação e autenticação. Os endereços de todos os servidores são freqüentemente mantidos como "hints". E informaçōes relativas ao servidor de nomes costumam ser armazenadas como "stashs"; dessa maneira se um serviço não responder, é possível utilizar a informação do "stash", mesmo que esteja desatualizada [MUL89,TER87].

\subsubsection{Memórias "Cache"}

"Cache" é outra maneira de manter cópias locais de dados remotos. As informações no "stash" e no "hint" podem estar erradas, mas a informação no "cache" deve estar correta. As memórias "cache" devem permitir que se tenha acesso virtual aos dados remotos com a mesma eficiência que aos dados locais [MUL89,TER87]. 
Santana, em [SAN90], classifica "cache" quanto a servidores de arquivos, generalizando o conceito da seguinte maneira:

-centralizado: o "cache" é implementado na memória principal do servidor do usuário;

-distribuído: é implementado em máquinas diferentes, incluindo outros servidores e clientes. Pode ser implementado tanto na memória principal quanto no disco.

Citam-se três possíveis implementações [SAN90]:

-"cache" no cliente: essa abordagem aumenta a disponibilidade dos dados, reduz os acessos à rede e aos servidores e pode ser implementada na memória principal do cliente ou em um disco.

-"cache" no senvidor de arquivos do usuário: é simples de implementar e diminui os acessos ao disco. E implementada na memória principal do servidor de arquivos.

-"cache" em outros servidores: essa abordagem diminui a distância entre as informaçōes e o usuário, podendo ser implementada na memória principal ou secundaria do servidor.

A maior dificuldade dessa técnica segundo Terry, em [TER87], é a garantia da consistência e validade dos dados armazenados em um "cache".

\subsection{Considerações Finais}

Neste capítulo, procurou-se caracterizar um sistema distribuído como um sistema único para o usuário, ficando para as camadas inferiores de software e de hardware o tratamento dos aspectos de distribuição e transparência.

Vários sistemas experimentais usam o modelo cliente/servidor com alguma forma de chamada de procedimento remoto como base de comunicação. Por outro lado, as técnicas 
de replicação, "cache-hint", "stash" e memórias "cache" têm se tornado mecanismos indispensáveis para melhorar o desempenho dos sistemas, evitando acessos remotos. 


\section{Capítulo 4}

\section{Serviço de Nomeação e Servidores de Nomes para Sistemas Computacionais Distribuídos}

Este capítulo discute tópicos relacionados com o serviço de nomeação fornecido pelos servidores de nomes, estando organizado nas seguintes seçōes: servidores de nomes, métodos para gerenciamento de nomes, convençōes de nomeaçāo, exemplos de servidores de nomes e serviços de nomeação existentes atualmente.

\subsection{Introdução}

Um servidor de nomes é um módulo de um sistema computacional distribuído cuja função é gerenciar o espaço de nomes do serviço de nomeação do sistema ("naming system"). A palavra "nome" no contexto de sistemas computacionais distribuídos, é usado como um identificador utilizado por seres humanos para se referir a objetos que procuram, aos quais desejam ter acesso ou com os quais desejam comunicar-se. Um nome transmite o sentido sobre "o que estamos falando" [ZAT92].

Mullender, em [MUL89], destaca a importancia do serviço de nomeaçāo da seguinte maneira: 
1)Se é necessária a identificação de um objeto em um sistema computacional, deve existir um mecanismo que permita atribui-lhe um nome.

2)Um nome em um sistema distribuido pode se referir a um objeto em uma máquina local ou remota.

3)O sistema deve ser capaz de descobrir a localização do objeto (dado seu nome).

4)Quando os objetos se movem no sistema torna-se difícil localizá-los e administrá-los.

5)A atividade de segurança do sistema está internamente ligada à atividade de nomeação.

Dessa maneira, Mullender, em [MUL89], define as principais funções do serviço de nomeação:

1)Permitir que usuários designem nomes aos objetos e que, subseqüentemente, usem esses nomes para se referir a esses objetos.

2)Deve fazer a ligaçāo ("binding") do nome ao objeto. Isto ocorre quando o serviço de nomes associa o nome ao endereço do objeto.

3)Um objeto é referenciado pelo seu nome, a localização do objeto associado ao nome $e$ descoberta pelo serviço de nomes que fornece o seu endereço ou caminho.

4)Deve ser capaz de "resolver" um nome, isto é deve identificar o endereço relacionado ao nome. Isto pode ser feito através de consultas a tabelas, por meio de um algoritmo, ou uma combinação dessas duas.

Champine, em [CHA90], destaca que o propósito principal do serviço de nomeação é desacoplar o suporte lógico da implementaçāo física do objeto. Dessa maneira, a reconfiguração do sistema é muito fácil, já que é necessário mudar apenas o mapeamento lógico-físico. Por outro lado, é conveniente que o sistema seja capaz de executar um mapeamento inverso, físico-logico, principalmente para máquinas sem memória secundária. 


\subsection{Servidores de Nomes}

O servidor de nomes é um elemento do sistema computacional distribuído encarregado de fornecer o serviço de nomeação do sistema.

Existem alguns fatores que afetam o projeto de um servidor de nomes, entre os quais podem-se citar: o número de tipos de objetos, o número de objetos, a frequiência das consultas, a freqüência de atualização, o nível de tolerância a falhas desejado, confiabilidade, eficiência, expandibilidade, e consistência [CHE84,CHA90].

A própria natureza dos sistemas distribuídos, nos quais servidores e objetos são colocados em diversos lugares, faz com que o projeto de um mecanismo de manipulaçāo uniforme e eficiente seja um problema muito difícil. Um dos problemas consiste em escolher onde o mapeamento do nome e onde sua interpretação devem ser feitos [CHE84].

\subsubsection{Serviço Centralizado}

No serviço centralizado o problema de nomeação é extremamente simples, pois é suficiente que o sistema mantenha uma tabela ou uma base de dados que forneça os mapeamentos nome-objeto. Portanto, a abordagem mais simples é implementar um único servidor de nomes. Dessa maneira, o servidor de nomes aceita um nome em um domínio lógico e o mapeia a um domínio físico e sua base de dados é construída registrando-se serviços, processos, usuários, etc [TAN85].

Esse modelo é bastante aceitável para sistemas distribuídos de pequeno porte, localizados em um mesmo lugar. Para sistemas distribuídos de grande porte essa abordagem fica inviável por três razōes destacadas por Tanenbaum em [TAN85] :

1)Um único componente centralizado pode causar a queda de todo o sistema, se esse único componente (servidor de nomes) falhar.

2)A presença de um único servidor de nomes em um sistema distribuído de tamanho considerável, pode causar uma sobrecarga no servidor, degradando a eficiência global do sistema. 
3)Em sistemas distribuídos geograficamente, os nós podem estar potencialmente distribuídos em diferentes cidades e um único servidor de nomes será ineficiente devido aos grandes atrasos para consultá-lo.

Para solucionar esses problemas decorrentes da existência de um único servidor de nomes, é apresentada uma abordagem distriburda, onde o sistema de nomeação é dividido em domínios, cada um com seu próprio servidor de nomes [TAN85].

\subsubsection{Serviço Distribuído}

Se o sistema é composto por múltiplas redes locais conectadas por "gateways" ou "bridges", parece natural adotar-se um servidor para cada rede local [TAN85]. Dessa maneira, aparece o primeiro problema a ser solucionado:

"Como organizar o espaço global de nomes já que este deverá ser dividido para ser gerenciado por vários servidores de nomes"

Se a implementação do serviço de nomeação distribuído é feita por meio de uma base de dados (como geralmente acontece), os métodos usuais para distribuição dos dados podem ser usados, incluindo replicação e particionamento [CHA90].

Uma base de dados replicada é criada com múltiplas cópias. A replicação tem a vantagem de fornecer um bom desempenho e confiabilidade, mas a atualizaçāo é difícil devido aos requisitos de sincronização. $O$ método de replicação requer muito espaço de armazenamento.

No particionamento, a base de dados é dividida em múltiplas bases de dados disjuntas. Devem ser fornecidos meios para identificar a partição correta, aquela contendo os dados de interesse. Isto pode ser feito através de uma busca de diretório ou por "broadcast". A vantagem do particionamento da base de dados é que só existe uma cópia dos dados, poupando espaço de armazenamento e simplificando a atualização. $O$ ponto negativo do método de particionamento da base de dados é que deve ser encontrado o 
particionamento correto, e em muitos casos várias partições deverão ser consultadas para resolver um nome.

Por outro lado, replicar a base de dados é muito mais confiável do que particioná-la [CHA90].

Muitos dos sistemas distribuídos tem seu serviço de nomeação implementado mediante a combinaçâo de particionamento e replicaçâo, para atingir um balanceamento entre os requisitos de desempenho e armazenamento. Muitos servidores de nomes também utilizam um sistema de "cache" para os nomes mais freqüentemente usados [TER87,CHA90].

\subsubsection{Gerenciamento de Nomes Distribuídos}

Gerenciar nomes envolve a manutenção de informações sobre objetos nomeados, ou seja, seus atributos, e o fornecimento de facilidades para manipular essas informações [TER86].

E necessário considerar que um sistema distribuído pode sofrer algumas mudanças no decorrer do tempo: novos recursos computacionais são adicionados, novos sistemas de software são incluídos, usuários são freqüentemente adicionados ao ambiente e mais ainda, mudar o nome de um objeto $e ́$ uma operação custosa porque todas as referências ao objeto se tornarão invalidas. Portanto os servidores de nomes necessitam de técnicas flexíveis para gerenciar cooperativamente os conjuntos de nomes dos objetos do sistema.

O gerenciamento de nomes distribuído dividido em três atividades principais que requerem a interação entre os servidores de nomes e entre servidores e seus clientes [TER86]:

-A designação do nome é realizada (ou pelo menos controlada) pelos criadores do objeto. Freqüentemente são concatenados mnemónicos a nomes desconhecidos pelo servidor de nomes e com o qual o nome é registrado.

-A distribuição dos nomes divide a responsabilidade de gerenciar partes do espaço de nomes entre "autoridades de nomes". Para grandes ambientes computacionais, 
nenhum servidor de nomes pode ter autoridade para todos os objetos.

-A resolução dos nomes consiste em determinar as autoridades de nomeaçáo para um objeto, dado seu nome. Uma vez descoberta a autoridade, podem ser solicitadas operaçôes para ler ou atualizar informação sobre o objeto, tal como a sua localização.

Terry, em [TER86], ressalta a necessidade de se separar essas três atividades: escolha dos nomes, seleção dos locais de armazenamento para os atributos dos objetos e a resolução do nome do objeto.

Se o sistema é capaz de distribuir nomes entre os servidores de nomes independentemente da estrutura que os nomes possuem, então os serviços de nomeação são facilmente reconfigurados em resposta a mudanças no ambiente. $E$ o que é mais importante, os clientes do serviço de nomeação não ficam conhecendo tais reconfiguraçōes, desde que o espaço de nomes se mantém o mesmo.

Se a seleçāo das autoridades de nomeaçāo para os objetos é feita independentemente dos nomes dos objetos, algumas das responsabilidades de um servidor de nomes sobrecarregado podem ser transferidas para um servidor menos carregado, o servidor pode ser promovido a um processador diferente ou obter mais espaço de disco, permitindo-lhe armazenar uma grande parte do espaço de nomes. Servidores adicionais podem ser introduzidos $e$ assim por diante.

Também é desejável separar a designação de autoridade do espaço de nomes da resolução do nome do objeto. Dessa maneira, o processo de resolução do nome pode ser dinamicamente ajustado para se adequar ao desempenho das operações do serviço de nomeação, sem causar impacto na designação de autoridade. Mais ainda, a distribuição dos atributos do objeto entre os servidores de nomes é ditada pelas preocupaçōes administrativas para garantir integridade e privacidade das informações sobre os objetos, uma vez que a informação requerida para resolver nomes é usada somente pelo serviço de nomeação [TER86]. 


\subsubsection{Nomes Externos e Identificadores Únicos}

Deve-se considerar que os nomes definidos pelos usuários não são únicos para um objeto particular e são de tamanho variável, não somente para objetos diferentes, mas mesmo para nomes diferentes do mesmo objeto. Portanto, tais nomes não podem ser facilmente manipulados, armazenados e usados pelas máquinas para identificaçāo. Assim, em adição aos nomes definidos pelos usuários, os quais são úteis para os usuários, alguns sistemas usam os nomes definidos pelo sistema ("flat names") e que portanto podem ser eficientemente usados pelo sistema [SIN91b].

Os nomes definidos pelo usuário são denominados "nomes externos", e os nomes definidos pelo sistema são chamados de "identificadores únicos" (ID) [SIN91b].

Inicialmente, o nome externo é mapeado para seu correspondente identificador único (ID), que por sua vez é mapeado para uma localização física do objeto em questão; se o objeto for replicado, é mapeado para a localização física de uma das réplicas. O processo de mapeamento do nome externo para seu correspondente identificador único (ID) é chamado de "resolução do nome", e o processo de mapeamento do identificador único (ID) para a localização física (das réplicas) do objeto é conhecido como a localização do objeto (Figura 4.1).

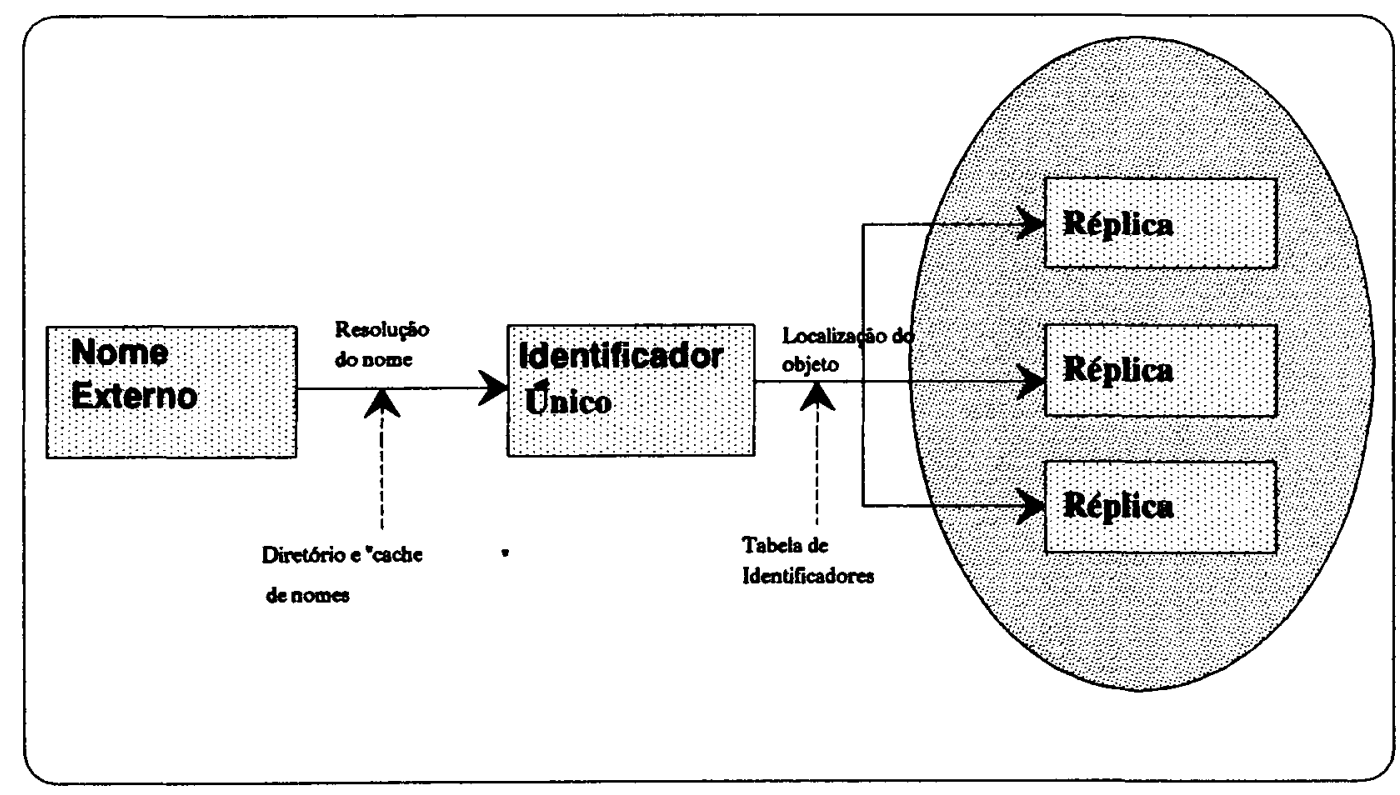

Figura 4.1 - Nomes Externos e Id. Único 
A resolução do nome geralmente $\epsilon$ uma consulta ao diretório ou a um "cache" de nomes, enquanto que a localização do objeto é uma consulta a uma tabela de identificadores únicos ou a uma base de dados.

\subsection{Modelos Centralizado e Distribuído de Resolução de} Nomes

O projeto de um sistema deve atingir requisitos de uniformidade, duplicaçāo mínima e flexibilidade além dos citados anteriormente: eficiência, confiabilidade, etc. [CHE84, ZAT92].

Uniformidade sugere que o sistema de nomeaçāo deva ser projetado para fornecer um uso uniforme de operaçōes nesses nomes, por exemplo "Delete(object-name)" deverá apagar o objeto especificado, independente do que é, como é implementado e onde reside. Minimizar a duplicação de funçōes sugere que a manipulação dos nomes seja isolada em um módulo de manipulaçāo que é disponível aos processos (servidor de nomes). O sistema deve ser flexível, isto é, não obrigar nenhuma sintaxe particular ou representaçōes de caracteres específicas, de tal forma que esquemas de nomeação distintos possam ser facilmente conectados por um único esquema de nomeação global.

Uma dificuldade do serviço de nomeação consiste em escolher onde será feita a resoluçāo de um nome e onde será feita a operaçāo de localização do objeto.

Podem-se citar dois modelos de soluçōes para esta dificuldade:

-Num modelo, o servidor de nomes logicamente centralizado fornece o serviço de mapeamento. $O$ modelo centralizado é motivado principalmente por considerações de uniformidade e duplicaçāo mínima das suas funçōes. Neste modelo, cada servidor, serviço, cliente, e objeto em geral apresenta o nome registrado ao servidor de nomes quando se refere a uma destas entidades.

-No segundo modelo, chamado distribuido, os nomes são armazenados junto com os objetos que representam. Esta abordagem é motivada por consideraçōes de 
eficiência, confiabilidade e expandibilidade. Esta abordagem não soluciona completamente o problema de nomeação, pois năo fica claro como achar um objeto dado seu nome, já que o nome é armazenado junto ao objeto.

Também há abordagens hrbridas desses dois modelos. Por exemplo: pode ser adotado um servidor de nomes logicamente centralizado, e fornecer uma implementaçāo distribuída, armazenando a definição dos nomes em lugares próximos aos objetos nomeados.

Em geral, as técnicas distribuídas aumentam a eficiência e a centralizada é usada para melhorar a funcionalidade.

\subsubsection{Comparação dos dois Modelos}

A abordagem centralizada tem a vantagem de localizar as operaçōes de manipulação de nomes em um servidor e assim impor um nivel de uniformidade ao sistema. Existem várias outras diferenças entre as duas abordagens, como por exemplo [CHE84]:

-Eficiência: Separar o nome do objeto de sua implementação introduz o custo extra de interagir com mais um servidor a cada nome referenciado.

-Consistência: Separar a implementação de nomeação da implementação do objeto nomeado torna mais difícil assegurar que a informação seja mantida consistente com os objetos nomeados.

-Poucos níveis de nomeação: Se os objetos e seus nomes são mantidos juntos, o mapeamento de um nome ao objeto associado é uma operação interna para o servidor que mantém os dois. No modelo centralizado, o servidor de nomes não pode mapear um nome ao objeto, mas sim mapeia para outro nome (identificador único) que possa ser usado diretamente no servidor que implementa o objeto. Assim um nível de nomeação a mais é requerido, entre o servidor de nomes e os outros servidores do sistema. 
-Expandibilidade: Um sistema distribuído tipicamente inclui numerosos e diferentes espaços de nomes já estabelecidos, servidores de nomes e interpretaçōes. Esses servidores já existentes se encaixam muito bem em um modelo distribuído, mas são difíceis de se acomodar em um sistema centralizado no qual o servidor de nomes transforma os nomes em identificadores únicos (universais) de baixo nível.

-Confiabilidade: No modelo distribuído, o nome estará acessível apenas se o objeto estiver acessível. No centralizado, o servidor de nomes se converte num ponto central de falhas, isto quer dizer que se o servidor de nomes falha todos os objetos serão inacessíveis aos clientes.

\subsection{Métodos para Gerenciamento de Nomes}

Como foi observado anteriormente, em um sistema computacional distribuído pode-se implementar o serviço de nomeação de maneira replicada, particionada ou mediante uma combinação das duas. Assim, existem vários métodos propostos e usados nos sistemas distribuídos existentes, destacando-se [SIN91b]:

- Método de "broadcast"

- Método de "hint-cache" e "broadcast"

- Método de encadeamento ("chaining")

- Método de servidor centralizado (nó único)

- Método de replicação completa

- Método de tabelas de prefixos

O método de "broadcast", $€$ aplicado em sistemas de nomeação particionados. Nesse método, uma consulta sobre um nome é feita a todos os servidores; o servidor de nomes que possua esse nome responderá ao cliente. Pode ser utilizado para atualizar todas as réplicas de um espaço de nomes. Não precisa manter informaçōes sobre as partiçōes nem as 
réplicas dos espaços de nomes [TAN85,SIN91b].

O método "hint-cache" e "broadcast" é aplicado para sistemas com serviço de nomeação distribuído em vários servidores de nomes, no qual os clientes mantêm um "hint-cache" dos nomes mais utilizados pelos clientes. A atualização dos "caches" pode ser feita por "broadcast" aos vários servidores [TAN85,SIN91b].

$O$ método de encadeamento é típico para serviço de nomes particionado. Os servidores de nomes mantêm, além do seu espaço de nomes, ponteiros ou direcionamentos para outros servidores. Essa abordagem é típica em sistemas de nomeação hierárquicos [TAN85,SIN91b].

O método de servidor de nomes único (centralizado) é o mais simples de implementar e é o mais adequado para sistemas distribuídos de pequeno porte, embora tenha pouca confiabilidade [TAN85,SIN91b].

O método de replicação completa copia o espaço de nomes global em todos os nós do sistema distribuído. Neste método o desempenho atingido é alto, mas os problemas para atualização e armazenamento são muito grandes, complexos e custosos [TAN85,SIN91b].

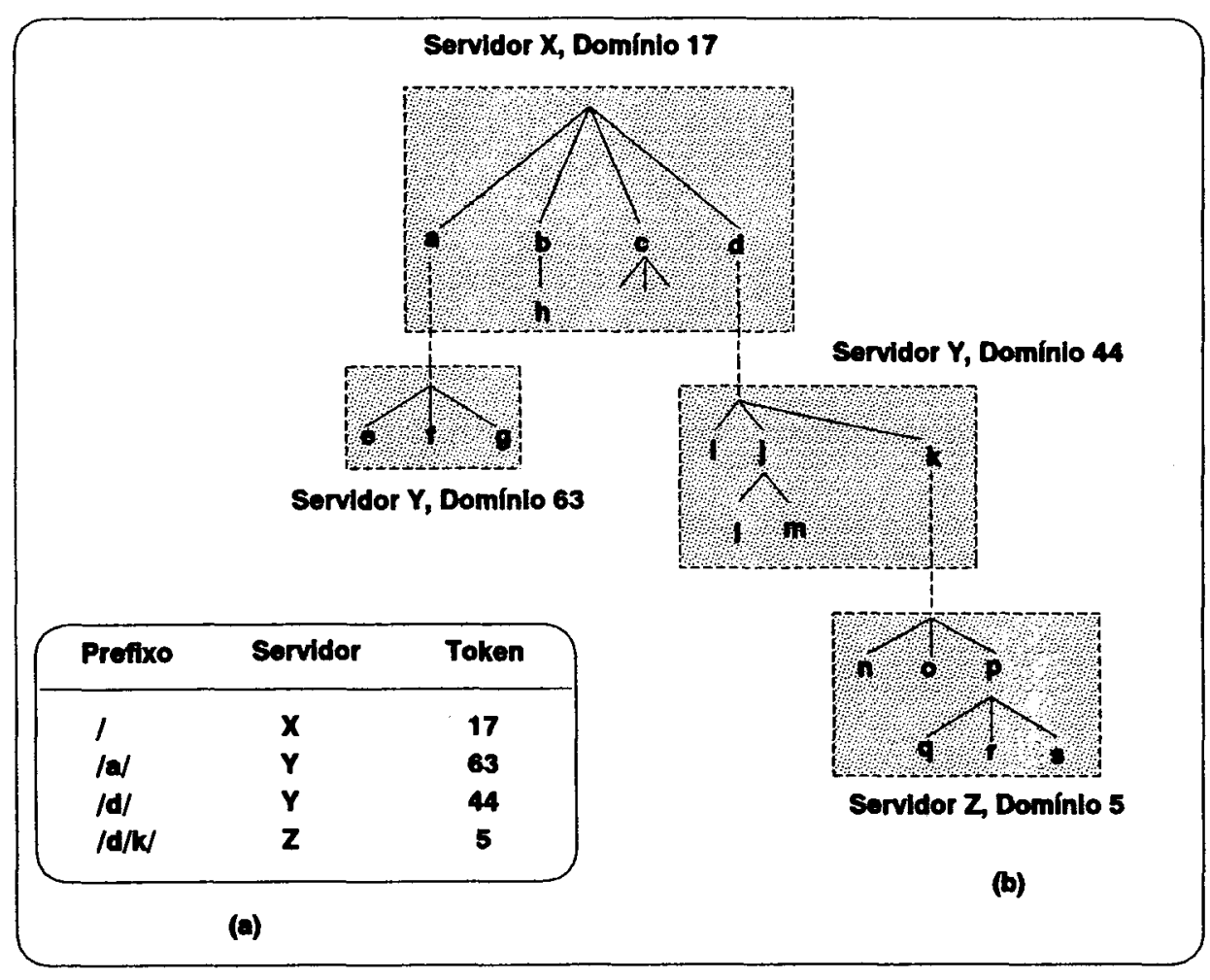

Figura 4.2 - Tabela de Prefixos 
No método de tabelas de prefixos, chamado também como gerenciamento das estruturas de domínio consiste em que cada núcleo das máquinas clientes mantém uma tabela de prefixos (Figura 4.2a). Cada entrada na tabela de prefixos corresponde a um domínio, fornecendo o nome completo do diretório de mais alto nível do domínio (ou seja, o prefixo compartilhado pelos nomes de todos os arquivos no domínio), o nome do servidor no qual aquele domínio $\varepsilon$ armazenado e um "token" adicional para passar ao servidor e identificar o domínio [WEL86,OUS88] (Figura 4.2b).

Como pode ser observado, o gerenciamento dos nomes pode ser centralizado ou replicado de acordo com os domínios de nomeação.

Existem ainda outras abordagens, como o gerenciamento de nomes livres de estrutura. Essa abordagem divide o espaço de nomes em contextos. Esse particionamento é feito de acordo com condiçōes de agrupamento, as quais são funções (expressões) aplicadas a espaços de nomes que permitem dividir e verificar a existência de um nome em um dado contexto. Essa abordagem garante que cada nome do sistema existe exatamente uma vez num único contexto. Dessa forma nâo existe restrição na estrutura dos nomes como acontece nos sistemas hierárquicos, por exemplo [TER86].

Existe uma relação entre os servidores de nomes que definem os nomes dos objetos e os próprios objetos. Por exemplo, vários servidores implementam os espaços de nomes que, embora fisicamente distribuídos entre múltiplos servidores de nomes, são entendidos como logicamente centralizados porque sua ação de resoluçāo de nomes é separada da ação de aceso ao objeto. Por outro lado, a distribuiçāo dos objetos dos servidores de nomes muitas vezes correspondem à distribuição dos objetos que eles nomeiam, onde a ação de acesso aos objetos ( isto é, seguir o caminho do fonte ao destino ) e a ação de acesso aos objetos dos servidores que geram os nomes que identificam o caminho, sāo separadas e indistinguíveis [COM89].

\subsection{Convenções de Nomeação}

A convenção de nomeação descreve como os clientes utilizando o serviço de nomeaçāo se referem aos objetos nomeados usando esta convenção [OPP83]. 


\subsubsection{Nomeação Relativa}

Na nomeação relativa, um objeto é nomeado dependendo da sua posiçāo relativa à posição do objeto que o está manipulando [SU82]. Por exemplo, o nome de um receptor de correio é tipicamente identificado pela rota do hospedeiro fonte ao receptor através de uma cadeia de hospedeiros conhecidos localmente, ligando assim o hospedeiro fonte ao receptor, como se observa a seguir:

receptor : alpha!beta!gamma!João

onde alpha é o hospedeiro fonte, beta é conhecido por alpha e assim por diante.

Para Oppen, em [OPP83], a convenção relativa é representada por meio de um grafo cujos nós não são rotulados, mas suas arestas sim. Existe zero ou uma única aresta rotulada de um nó a outro. Se existe uma aresta rotulada $i$ de $u$ até $v$, então o nome distinguido de $v$ relativo a u é i. Onde u é o cliente e v o objeto nomeado (Figura 4.3b).

\subsection{Exemplos de Servidores de Nomes e Serviços de Nomeação}

\section{O servidor de nomes CSNET [SOL82]}

O servidor de nomes CSNET pertence à rede lógica CSNET a qual usa os serviços fornecidos pela Arpanet, Telenet e pela Phonenet. O servidor de nomes é implementado por uma base de dados central, localizada na Universidade de Wisconsin (USA) e por um software sendo executado em Wisconsin e nos computadores das instituições membros da CSNET. A principal atividade do servidor de nomes CSNET é facilitar o envio de correio eletrônico, através de diretórios que fornecem os endereços dos "mailboxes", bem como estabelecem "aliasses" ou pseudônimos.

A base de dados do servidor de nomes inclui a informação do diretório para usuários e hospedeiros CSNET registrados. Essa informação é distribuída em uma base de dados 
central, que reside no hospedeiro de serviço (em Wisconsin), em tabelas nos hospedeiros que originam correio e em tabelas para usuários, mantidas para o sistema de correio local. O software que permite $\mathrm{o}$ acesso e as alteraçōes na base de dados central é chamado de "registrer" e reside no hospedeiro de serviço.

$O$ acesso à base de dados do servidor de nomes é feito diretamente, através do envio de mensagens ao "registrer", ou mediante o uso de um programa agente do servidor de nomes, cujas cópias residem nos hospedeiros membros do CSNET.

\section{Servidor de nomes Hesiod [CHA90]}

Hesiod é o servidor de nomes do sistema computacional distribuído Athena, desenvolvido no MTT (Instituto Tecnológico de Massachusetts, USA) com apoio da DEC (Digital Equipment Corporation) e da IBM.

O propósito do sistema Hesiod é permitir uma ligação dinâmica centralizada, entre nomes e objetos, através de um arquivo de configuração centralizado, para todas as estaçōes, fornecendo significantes reduções de armazenamento e fazendo com que as mudanças na configuração do sistema sejam gerenciadas com um mínimo de trabalho.

Hesiod fornece informação sobre usuários, localização de arquivos, endereços para o envio de correio e localização dos serviços da rede, tais como, autenticação e impressão. Hesiod é atualizado por uma base de dados central a cada certo tempo.

$O$ uso de uma base de dados centralizada tem demonstrado ser econômico e efetivo pois os dados são armazenados uma única vez e são facilmente atualizados.

\section{Mecanismo de localização de objetos do Galaxy [SIN91b]}

O sistema operacional distribuído Galaxy pertence à classe dos sistemas com banco de servidores (modelo estação de trabalho/servidor). Em Galaxy, todas as entidades que precisam ser identificadas pelo sistema são tratadas como objetos, onde cada objeto pertence a um tipo. Galaxy gerencia cada tipo de objeto com um mbdulo especial dedicado ao tipo, chamado gerenciador de objetos, o qual reside nos nós onde existem objetos desse 
tipo.

O mecanismo de localização de objetos do Galaxy é baseado em uma tabela de mapeamento, onde cada entrada consiste em informação sobre a localização de um objeto. Em particular, a entrada contém informação sobre o tipo do objeto, uma lista de controle de acesso para o objeto, posiçōes das réplicas dos objetos (lista de réplicas) e as posições onde existem cópias da tabela de mapeamento (lista de cópias).

Nos nós particulares de Galaxy só é mantida informação sobre a localização de objetos que tenham alguma possibilidade de ser requisitados a partir daquele nó. As tabelas dos nós são montadas a partir das seguintes premissas:

1)São armazenados os identificadores contidos no diretório ou no "cache" de nomes desse nó.

2)São armazenados os identificadores dos processos sendo executados no nó.

\section{Sistema de nomeação Clearinghouse [OPP83]}

Clearinghouse é um agente descentralizado desenvolvido pela Xerox para o suporte de nomeação de objetos visíveis em um ambiente distribuído de uma rede. Clearinghouse liga o nome do objeto a um conjunto de propriedades de vários tipos. Clearinghouse é descentralizado e replicado, ou seja, no lugar de um único servidor global existem vários servidores Clearinghouse, cada um armazenando uma cópia de uma partição do espaço de nomes global. A totalidade de serviços fornecidos por todos os servidores é conhecida por Clearinghouse. A replicação e a descentralização levam a um aumento de eficiência, segurança e confiabilidade do sistema.

As requisiçōes destinadas ao Clearinghouse podem-se originar em qualquer lugar do sistema e devem ser dirigidas a um servidor Clearinghouse. $O$ cliente não se preocupa em saber quem mantém a ligaçāo do nome ao objeto, pois isto é função dos "stubsclearinghouse", os quais sāo mantidos nas estaçōes clientes e nos servidores Clearinghouse. Os "stubs" acham automaticamente os mapeamentos se estes existem. 
Atualizaçōes das várias cópias de um mapeamento podem ocorrer assincronamente e não são tratadas como transaçōes atômicas (operações indivisíveis). A inconsistência resultante entre as várias cópias é temporária, Clearinghouse trata automaticamente dos conflitos de atualização e restabelece a consistência.

\section{Servidor de nomes Univers [BOW90]}

Univers é um servidor de nomes baseado em atributos que oferece um mecanismo de bloco de construçāo, sobre o qual vários serviços podem ser implementados. Univers pode funcionar como um componente organizacional no sistema DNS ("domain name system"); participar em um diretorio usuário global tal como o X.500 ou o Profile; servir como um locador de recursos de uma organização; implementar a biblioteca de mapeamento de nomes do Unix e dar suporte a consultas diretas de programas e usuários.

Univers consiste de uma base de dados relacional para armazenar informaçōes sobre os recursos, um interpretador de programa que serve de auxálio à base de dados ("front-end"), uma estrutura de trabalho que da suporta acesso remoto e um gerador de atributos.

A base de dados e o interpretador são a base do paradigma de nomeação baseado em atributos que permite aos clientes identificar objetos a partir de um conjunto de atributos ou propriedades que descrevem o objeto.

O paradigma de nomeação baseado em atributos é suficientemente poderoso para fornecer: o serviço de página branca que identifica usuários e organizaçôes a partir de descriçōes imprecisas, o serviço de página amarela que identifica recursos computacionais, a partir da combinaçāo exata das propriedades que o recurso deve possuir e um sistema convencional que mapeia nomes simples em endereços (ver capítulo 5).

\section{Profile: servidor de página branca [PET88,BOW90]}

Profile é um servidor de página branca que permite aos usuários identificar usuários e organizaçōes a partir de um conjunto de atributos. $O$ objeto fundamental de Profile é o 
"principal", ou seja, o usuário ou organização que patrocina uma coleção de recursos, isto $\varepsilon$, gerencia, $e$ dono ou tem alguma responsabilidade pelos recursos. Dos recursos patrocinados pelos "principais" o mais importante é o servidor de nomes, o qual fornece informação sobre "principais" a partir de um conjunto de atributos que the é fornecido. O servidor de nomes é a autoridade de nomeação para o conjunto de "principais" cujos nomes pode resolver. Por exemplo, uma lista de endereços de correio eletrônico, um grupo de usuários ou um grupo de interesse especial pode patrocinar um servidor de nomes que é a autoridade de nomeação para os membros do grupo. Qualquer "principal" pode patrocinar um servidor de nomes e cada servidor de nomes pode ser autoridade de nomeação para qualquer conjunto de "principais".

Um servidor de nomes consiste de três componentes: uma base de dados de atributos para um conjunto de principais, um grupo de funçōes de interpretaçāo e algumas ferramentas para gerenciar a base de dados.

Profile foi motivado e implementado na rede DARPANSF ("Defense American Research Project Agency -National Science Foundation") "internet" [PET88], como também tem sido implementado no topo do servidor Univers [BOW90].

\section{Serviço de informação de rede (NIS) [SUN90, TAN92]}

NIS é um servidor de página amarela que fornece serviço de nomeaçāo ao sistema operacional de rede SunOS. E um mecanismo para identificar e localizar objetos e recursos acessíveis à comunidade.

As bases de dados do NIS, melhor conhecidas como mapas, são distribuídas entre várias máquinas e são atualizadas a partir de uma base de dados central de uma maneira automática e confiável, assegurando assim que os clientes compartilhem as mesmas bases de dados de uma maneira consistente através da rede.

Existem duas variedades de servidores NIS: mestre ou escravo. A máquina designada como servidor mestre contém o conjunto de mapas que podem ser atualizados quando necessário. O servidor escravo mantém uma ob́pia completa do conjunto de mapas do NIS. Sempre que os mapas do servidor mestre são atualizados, este propaga as atualizações aos servidores escravos. 
Os clientes do NIS executam processos que requisitam dados dos mapas através de um processo de ligação ("binding process"). O processo cliente usa um "broadcast-rpc" para iniciar a ligação com um servidor NIS.

\section{Sistema de nomeação por domínios (DNS) [SUN90,COM91]}

O DNS é um protocolo da camada de aplicação que forma parte do padrão de protocolos TCP/IP. E o mecanismo que implementa a hierarquia dos nomes das máquinas no TCP/IP. Conceitualmente, o DNS tem duas funçōes principais: a primeira é especificar a sintaxe dos nomes e as regras para designar autoridade sobre os nomes, e a segunda especifica a implementação do sistema computacional distribuído que mapeia eficientemente os nomes em endereços [SUN90].

O DNS utiliza um esquema de nomeação hierárquico conhecido como nomes de domínio. $O$ nome de domínio consiste em uma seqüência de subnomes separados por um caractere delimitador ("."). Os nomes dos domínios são escritos com o domínio local primeiro e o domínio superior no final [COM91], por exemplo, icmsc.usp.br.

O sistema de nomeação por domínios realiza a nomeação dentro do domínio administrativo local e através dos limites do domínio. O DNS é distribuído entre um conjunto de servidores de nomes. Este sistema de nomeação introduz o conceito de zonas. A zona corresponde a uma comunidade hierárquica de hospedeiros administrada por uma única autoridade e servida por um conjunto de servidores de nomes. As zonas usualmente representam os limites administrativos, tais como, o domínio administrativo local.

Do lado do cliente, o serviço é implementado por meio de um processo chamado "resolver", cuja função é resolver consultas do usuário, para isso ele precisa conhecer pelo menos um endereço de um servidor de nomes. $O$ servidor de nomes pode retornar a resposta desejada ou uma referência a outro servidor. 


\section{Sistema Lego [HUG93]}

Lego $€$ um núcleo baseado em mensagens, desenvolvido para o estudo de sistemas distribuídos $e$ algoritmos relacionados.

Seu servidor de nomes chamado "Who" permite que um objeto registre seu nome e seu identificador para consultas futuras. O servidor Who é completamente distribuido de tal forma que cada processador executa sua propria cópia do serviço Who. O serviço Who local mantém sua própria lista de nomes locais e identificadores. Todos os servidores Who compartilham o mesmo identificador.

Para registrar um nome, um objeto envia uma mensagem contendo seu nome e identificador a seu servidor Who local. Para obter o identificador de um objeto (serviço), um cliente envia uma mensagem contendo o nome do objeto requisitado, a todos os possíveis servidores de nomes ("broadcast"), já que estes existem tanto no processador local quanto nos remotos. Após receber uma requisição, aqueles servidores Who que armazenam o nome do objeto requisitado, respondem com uma mensagem contendo o nome do identificador.

\subsection{Considerações Finais}

Este capítulo considerou vários aspectos relacionados ao serviço de nomeaçāo fornecido em um ambiente computacional distribuído e aos módulos do sistema ("servidores de nomes") encarregados de fornecer esse serviço.

Um dos aspectos a destacar, é a importância do servidor de nomes no desempenho global dos sistemas computacionais distribuídos. Dessa maneira, foram analisadas as principais abordagens de implementação de um servidor de nomes centralizado e de um servidor distribuído, junto às suas características principais. Consideram-se também os modelos de resoluçáo de nomes e os principais métodos para gerenciamento de nomes, podendo observar que sua implementaçāo implica diretamente no desempenho geral do sistema. 
Sheltzer, em [SHE86], analisa pormenorizadamente 0 aumento de desempenho $e$ as reduções do tempo de acesso a recursos remotos, através do uso de "caches" de nomes, o que constitui um elemento indispensável na maioria dos servidores atuais .

O maior problema na área de nomeação atualmente consiste em descobrir novos paradigmas que permitam estruturar esta ampla área de sistemas computacionais distribuídos de tal forma a obter novos modelos de nomeação e busca de informação [BRY93].

Por outro lado, é importante salientar duas linhas de pesquisa na área de servidores de nomes que Comer, em [COM89], ressalta: a importância das pesquisas de projeto de sistemas de nomeação que fornecem suporte a nomes baseados em atributos [PET88,BOW90,VEL93], e os projetos de mecanismos que fornecem nomeaçāo de recursos em sistemas computacionais heterogêneos. 


\section{Capítulo 5}

\section{Modelo de Nomeação Baseado em Atributos}

Este capítulo revisa o modelo de nomeação baseado em atributos, proposto por Bowman em [BOW90], o qual $e$ analisado sob pontos de vista estrutural e funcional. Esta análise constitui a base teórica para a implementação da infra-estrutura de um núcleo para um serviço de nomeaçāo baseado em atributos.

\subsection{Introdução}

A concepção de um servidor de nomes tradicional, como pôde ser analisada no capítulo anterior, sugere um mecanismo que mapeie elementos de um domínio lógico para um domínio físico, ou vice versa. Em muitos casos o servidor de nomes deve armazenar certas características relevantes dos recursos de um sistema computacional distribuído, as quais se tornam disponíveis ao sistema através de consultas ao servidor. Essas características podem ser relacionadas a fatores de segurança, podendo assim organizar o acesso a certos elementos do sistema mantendo critérios de prioridades.

Essas informaçōes sâo normalmente mantidas em uma representaçāo lógica por meio de tabelas, sendo que na maioria dos casos são de acesso exclusivo do sistema operacional distribuído, o qual através de consultas precisas obtém as informaçōes requeridas. 
A exclusividade de utilização do servidor de nomes por parte do sistema computacional e as limitaçōes dos tipos de informaçōes armazenadas por um servidor de nomes convencional, fazem com que o Modelo de Nomeação Baseado em Atributos surja como uma alternativa bastante atrativa para a implementação de servidores de nomes, pois tem entre suas características principais: permitir tanto aos usuários como ao sistema o acesso às informaçōes do servidor e que estas consultas possam ser baseadas tanto em dados precisos do objeto ou recursos em questão, quanto em dados imprecisos. Esses dados sâo as informaçōes dos objetos conhecidas pelos clientes, mantidas pelo servidor, a partir das quais são feitas as consultas.

\subsection{Modelo de Nomeação Baseado em Atributos [BOW90]}

O modelo de nomeaçāo baseado em atributos proposto por Bowman em [BOW90], pode ser analisado no seu comportamento funcional e na sua base estrutural, segundo a implementaçāo do servidor de nomes "Univers".

\subsubsection{Visāo Estrutural}

O modelo caracteriza-se por manter os objetos do sistema em uma base de dados, onde cada um desses objetos pode representar tanto "recursos externos", como usuários, máquinas, impressoras, etc., quanto "abstraçōes intemas" ao modelo, como tipos, contextos e funçōes, as quais têm uma relevância interna exclusiva ao servidor de nomes que implementa o modelo.

Os objetos sâo definidos através de um conjunto de atributos, cada um dos quais "constitui uma entidade sintática que denota uma propriedade ou característica do recurso ou abstraçāo representada pelo objeto" [BOW90]. Cada atributo é representado por um par < rótulo, valor >, assim uma dada máquina é representada por um objeto através um conjunto de atributos de forma: 


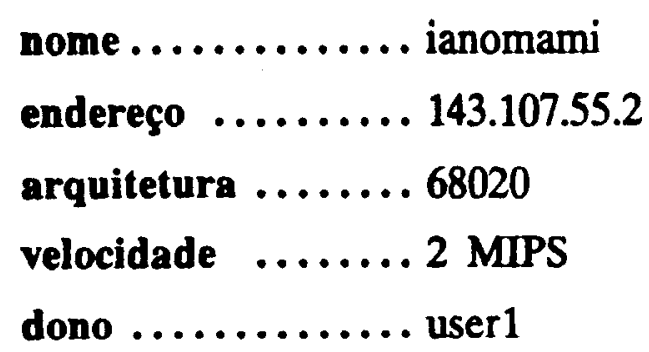

onde o primeiro atributo é dado pelo rótulo "nome" e pelo valor "ianomami". O conjunto de atributos que descreve o objeto é chamado de "nome baseado em atributos". Os clientes que requisitam informaçōes de um servidor de nomes projetado segundo esse modelo, podem ser usuários do sistema bem como processos de outros módulos (clientes ou servidores) do sistema computacional distribuído. As consultas ao servidor sāo feitas por meio de "programas de nomeação", os quais computam os conjuntos de objetos descritos pelos nomes baseados em atributos. Para isso, é necessário que os programas de nomeação sejam interpretados no servidor de tal forma que este retorne os objetos identificados pelo programa. Programas de nomeação nāo são mais do que funçôes aplicadas a conjuntos de atributos.

Um exemplo de um programa de nomeação que retorna uma ou mais máquinas que atendam a certos requisitos, pode ser escrito da seguinte maneira:

Obter_Máquinas ( arquitetura $=68020$, velocidade $=2$ )

A resposta do servidor a uma requisiçâo desse tipo, deve vir acompanhada pelo conjunto de todos os atributos (armazenados na base de dados do servidor) associados às máquinas que tenham processador $68020 \mathrm{e}$ cuja velocidade seja 2. As unidades para valores, como neste caso velocidade, devem ser previamente estabelecidas na fase de projeto. Para velocidade, por exemplo se utilizam MIPS (Millions of Instructions Per Second).

A título de exemplificação, o servidor poderá retornar os seguintes nomes baseados em atributos para a consulta acima: 


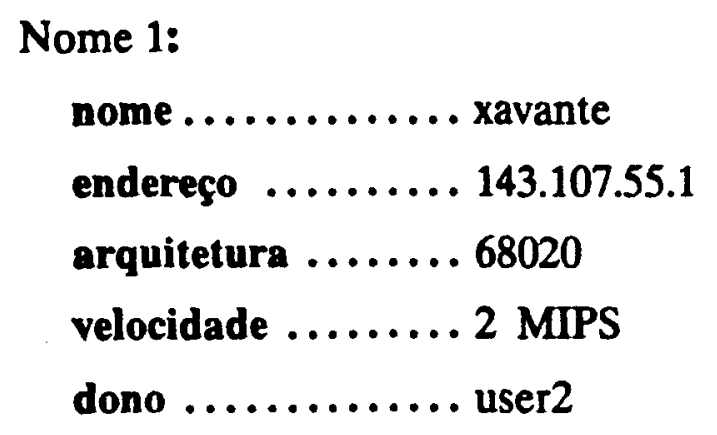

Nome 2:

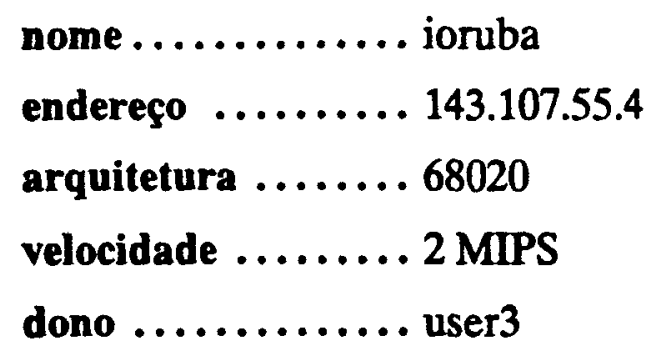

Normalmente os programas de nomeação são dados por composições de funçōes primitivas. Seguindo o raciocínio do exemplo anterior, pode ser que o cliente deseje conhecer alguma característica particular das máquinas, além dos requisitos por ele impostos no exemplo anterior. Dessa maneira, se apenas o nome das máquinas é desejado, pode-se submeter o seguinte programa de nomeação:

Projete(Obter_Máquinas(arquitetura =68020,velocidade =2),nome)

para o qual o servidor retornará:

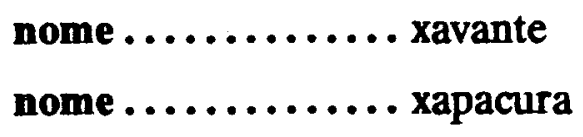

Os atributos, internamente na base de dados, são armazenados com a seguinte estrutura: 


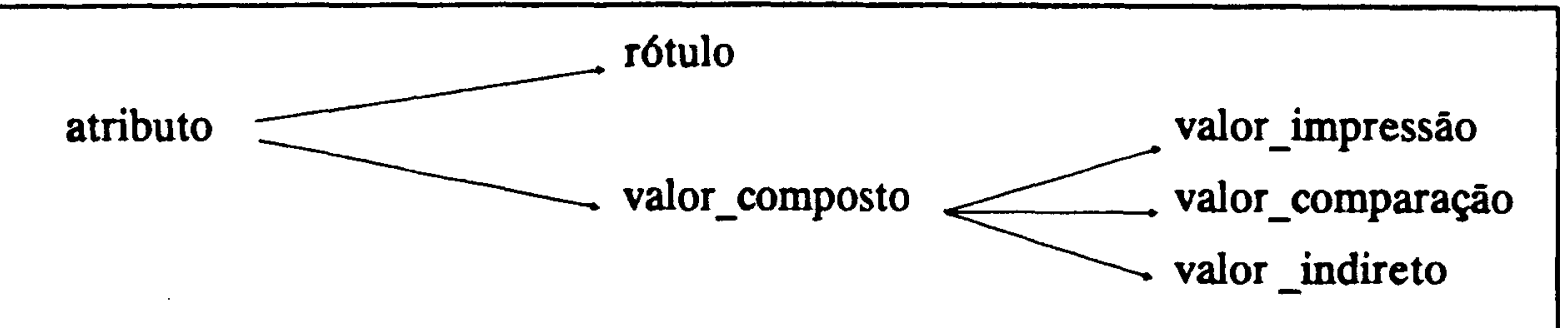

O rótulo é uma cadeia de caracteres que identifica o atributo e serve como indicação sobre o significado do atributo. Os valores do atributo denotam a propriedade atual sobre determinada característica do objeto. Internamente os atributos são compostos por três tipos de entidades que denotam o valor: o valor de impressāo é uma cadeia de caracteres legivel que é usada na impressão do valor quando este é requerido; o valor de comparação é a cadeia de caracteres representada por uma expressão regular. Em muitos casos o valor de impressão e o valor de comparação são iguais. O valor indireto aponta para outros objetos na base de dados; normalmente é utilizado na manutenção dos objetos com informaçōes dinâmicas (item 5.2.2). A representação do valor de comparação como uma expressāo regular tem como objetivo facilitar as consultas feitas ao servidor. Assim um atributo de um determinado objeto definido como:

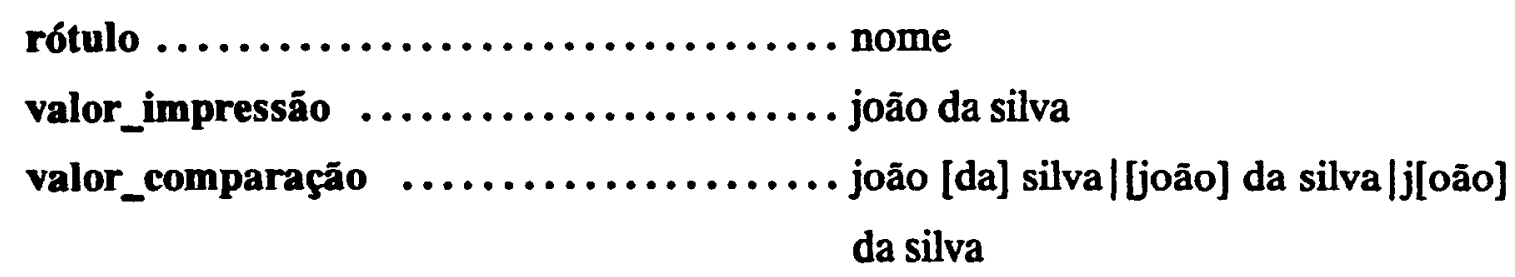

tornará possível a localização de um objeto que tenha como nome joão da silva, ou, joão silva, ou da silva ou simplesmente j da silva.

Assim, um servidor de nomes baseado em atributos permite que seus clientes consultem as informações por ele mantidas na base de dados, a partir de um conjunto de características que ele desejar ou tiver disponível, podendo assim obter informaçōes de objetos a partir de informaçōes imprecisas. Por exemplo, o cliente pode nāo conhecer um determinado valor do atributo de algum objeto e tentar descobri-lo fazendo consultas através dos atributos que ele conheça. 
Além dessas características, este modelo permite que o servidor organize e gerencie o espaço de nomes, mediante a representação de tipos de objetos, permitindo a criação de diferentes classes de contextos e ainda deixando a critério do cliente a criação de programas de nomeação (funções), fornecendo assim "estruturas organizacionais de mais alto nível", chamadas de abstrações internas.

A seguir definem-se as estruturas e características das abstraçōes internas do modelo de nomeação baseado em atributos:

\section{Funções}

Um programa de nomeação é uma estrutura de alto nível, que é definido pelo usuário e armazenado na base de dados do servidor como um outro objeto do sistema. Os programas de nomeaçāo quando apresentados ao servidor de nomes, são transformados em estruturas de mais baixo nível, que correspondem a seqüências de operações primitivas que têm acesso direto à base de dados. Na Tabela 6.1 (página 73), são descritas detalhadamente as funçōes primitivas (operações básicas) sugeridas no modelo de nomeação baseado em atributos.

\section{Tipos}

Um tipo em um modelo de nomeação baseado em atributos, corresponde a uma coleção de objetos que exibem similaridades estruturais. Um tipo é criado através de uma função primitiva, sendo necessário definir seu nome e suas características estruturais representadas por uma lista não vazia de rótulos, conhecidos como rótulos necessários.

Um determinado objeto pertence ao tipo $\mathrm{T}$ se e somente se, o conjunto de rótulos dos seus atributos é um superconjunto dos rótulos necessários do tipo T. Dessa maneira, um tipo impressora laser pode ser definido pelos rótulos \{velocidade, arquitetura, nome, fontes\} e será um subtipo do tipo impressora definido por \{nome, arquitetura, velocidade\}.

Todos os tipos de objetos têm um nome e uma lista de rótulos necessários associados a ele sendo armazenados como objetos da base de dados. 


\section{Contextos}

O sistema de nomeação baseado em atributos separa os objetos da base de dados, baseado na autoridade responsável por administrar esses objetos. As partiçōes são chamadas de Contextos e da mesma maneira que os tipos, os contextos também são criados mediante uma funçāo primitiva. Para sua criação é necessário a definição de um nome para o contexto, os objetos que são mantidos no contexto, o dono do contexto e para sistemas onde as funções do contexto estão divididas, é necessário especificar em que servidor de nomes o contexto está implementado. Os objetos são inseridos e removidos dos contextos, através de funçōes primitivas.

O modelo diferencia os contextos em função da autoridade que os gerencia. Dessa forma tem-se: (a) contextos de "sistema", cuja autoridade é o super-usuário e neles são armazenados os objetos referentes ao sistema; (b) os contextos de "aplicaçāo", que serão administrados pelo usuário ou grupo responsável por uma determinada aplicação instalada no sistema, nesse contexto são armazenados os objetos manipulados pela aplicação; (c) e os contextos de "usuários", que são administrados pelos usuários que criaram o contexto ou no nome dos quais foi criado o contexto, aqui são mantidos os objetos que esse usuário manipula no servidor.

Também são definidos os meta contextos, que armazenam: o conjunto de objetos que correspondem a cada contexto, os tipos de objetos para os tipos, os contextos e as funções definidas pelos clientes.

Finalmente, para cada cliente que consulta o servidor de nomes, é criado um contexto de sessão, o qual armazena todos os objetos manipulados pelo cliente durante a sessāo. Quando a sessão é encerrada, o contexto de sessão associado é destruído. 


\subsubsection{Visão Funcional}

O modelo baseado em atributos apresenta quatro componentes básicos, com suas funçōes claramente definidas. Dois desses componentes: a base de dados e o interpretador de comandos "conformam o núcleo essencial do modelo de nomeação baseado em atributos" [BOW90]. Os outros dois módulos - o gerenciador de acesso remoto e o gerador de atributos - complementam as atividades, fornecendo a infra-estrutura para a comunicação e um mecanismo de atualização das informaçōes relacionadas às características dos objetos mantidos no servidor.

A seguir são descritas as principais funções de cada um desses módulos:

\section{Base de Dados}

A base de dados é encarregada de manter as informaçōes dos objetos tanto externos ao servidor de nomes (por exemplo recursos computacionais) quanto internas ao servidor (as abstraçōes internas). Em função dos objetos ser representados através de conjuntos de atributos, a base de dados torna-se uma tabela de atributos, sobre a qual os programas de nomeaçāo operam diretamente.

\section{Interpretador}

Este módulo serve como "front-end" para o acesso à Base de Dados. No servidor de nomes "Univers" [BOW90], o interpretador 6 implementado usando o FLEX, que $\varepsilon$ um gerador de análise léxica compatível com o Lex ("Lexical generator"), e pelo YACC ("Yet Another Compiler-Compiler"), que se encarrega de gerar um analisador sintático. Os dois geram c6digo fonte na linguagem $\mathrm{C}$, 0 que permite que $\mathrm{o}$ acesso à base de dados seja implementado em $C$, oferecendo alto grau de compatibilidade na programação dos módulos. Além disso, é também possível a implementação de funções de nomeação mediantes chamadas a rotinas Unix, o que pode permitir acesso a sistemas como o DNS 
("Domain Naming System"), com relativa facilidade.

\section{Gerenciador de Acesso}

O gerenciador de acesso constitui o mecanismo de comunicação, através do qual os clientes submetem seus programas de nomeação ao servidor de nomes, e este retorna os resultados das operaçōes associadas ao programa.

$\mathrm{Na}$ implementação do "Univers", existem vários protocolos de acesso ao servidor, cada um dos quais conecta o servidor com o sistema por meio de um ou mais canais de transporte.

O gerenciador de acesso precisa de um filtro (procedimento Stub) para cada protocolo de acesso, por meio do qual recebe filas de bytes, as quais dependendo da semântica do protocolo são transformadas em programas de nomeação e submetidas ao interpretador para a execução do programa. De modo similar, o servidor, por meio do gerenciador de acesso, transforma os resultados para o respectivo formato do protocolo e envia a mensagem resposta ao cliente.

Para consultas diretas, o filtro é nulo, mas o gerenciador de acesso é responsável pela autenticação do cliente, o que permite limitar o acesso aos contextos que o cliente pode manipular e modificar. Para cada conexão estabelecida o gerenciador de acesso é responsável pela criação e destruição dos contextos de sessão.

\section{Gerador de Atributos}

Os atributos denotam as propriedades dos recursos do sistema. Algumas propriedades sofrem poucas alteraçōes ao longo do tempo, como por exemplo a velocidade de um processador ou sua arquitetura. Os atributos que apresentam mudanças lentas nas suas propriedades são ditos "estáticos". Duas funçōes, uma que adicione atributos e outra que remova atributos, são suficientes para manter atualizados os atributos estáticos dos objetos. Outras propriedades sofrem mudanças rápidas, como por exemplo, o dono de uma determinada máquina, e essas propriedades são ditas "dinâmicas". As funçōes que 
adicionam e removem atributos não são suficientes para manter atualizados os atributos dinâmicos. Assim, no servidor de nomes "Univers" é acoplado um mecanismo chamado Gerador de Atributos, que permite manter atualizado os atributos dinâmicos dos objetos da base de dados.

No "Univers", o gerador de atributos é um procedimento desenvolvido na linguagem $C$ que é chamado para computar o valor atual de um atributo dinâmico. Os geradores de atributos são armazenados na base de dados, "no lugar dos valores dinámicos". O procedimento que implementa o gerador consulta diretamente o próprio objeto e retorna $o$ valor atualizado. O valor retornado pode ser mantido em um "Cache" na base de dados e reutilizado em consultas posteriores. Portanto, o gerador poderá ser chamado somente quando o valor é necessário para resolver uma consulta e se seu respectivo valor no "Cache" está desatualizado.

Pode-se ainda otimizar o servidor, de tal forma que um único gerador seja associado a um conjunto de atributos, de tal forma que quando o gerador seja acionado por um dos atributos do conjunto, este retorne valores atualizados para cada um dos outros atributos. Por exemplo, quando for preciso atualizar o valor de carga de uma máquina, todos os valores de carga das máquinas serão atualizados e mantidos no "Cache".

\subsection{Considerações Finais}

Neste capítulo foram abordados os principais conceitos que devem ser levados em consideraçāo no projeto e implementação de um servidor de nomes que ofereça um serviço de nomeação baseado em atributos.

Um servidor desse tipo constitui, segundo Bowman [BOW90], "um mecanismo de bloco de construção, sobre o qual vários serviços de nomeação de alto nível podem ser implementados", já que apresenta uma infra-estrutura apropriada para realizar as ligaçōes ("binding") e para efetuar a resolução de informaçōes de nomeaçâo de forma adequada.

O servidor de nomes "Univers" fornece um suporte explícito para a manutenção de atributos contidos em uma base de dados precisa $e$ atualizada. 
Esse tipo de servidor de nomes pode ser projetado para ser usado por uma organização autônoma conectado a uma rede de computadores; pode também funcionar como um componente organizacional do DNS ("Domain Naming System") ou participar de um serviço de diretório global X.500 [BOW90]; pode ainda servir como alocador de recursos de uma organizaçāo e dar suporte a consultas diretas dos usuários e de outros programas (Figura 5.1). Esse modelo, definido por Bowman como um "Paradigma de Nomeação Baseado em Atributos" é suficientemente poderoso para fornecer: (a) o serviço de página branca que identifica usuários e organizaçōes a partir de descrições imprecisas; (b) o serviço de página amarela que identifica recursos computacionais, a partir da combinação exata das propriedades que o recurso deve possuir e (c) um sistema convencional que mapeia nomes simples em endereços [BOW90].

O "Univers" foi projetado sobre estaçōes de trabalho Sun, utilizando como ferramenta de programação a linguagem $\mathrm{C}$ e os geradores de aplicação FLEX e YACC. Atualmente está disponível uma nova versão "Beta" do "Univers" totalmente desenvolvida na linguagem Scheme [JON86,DYB87].

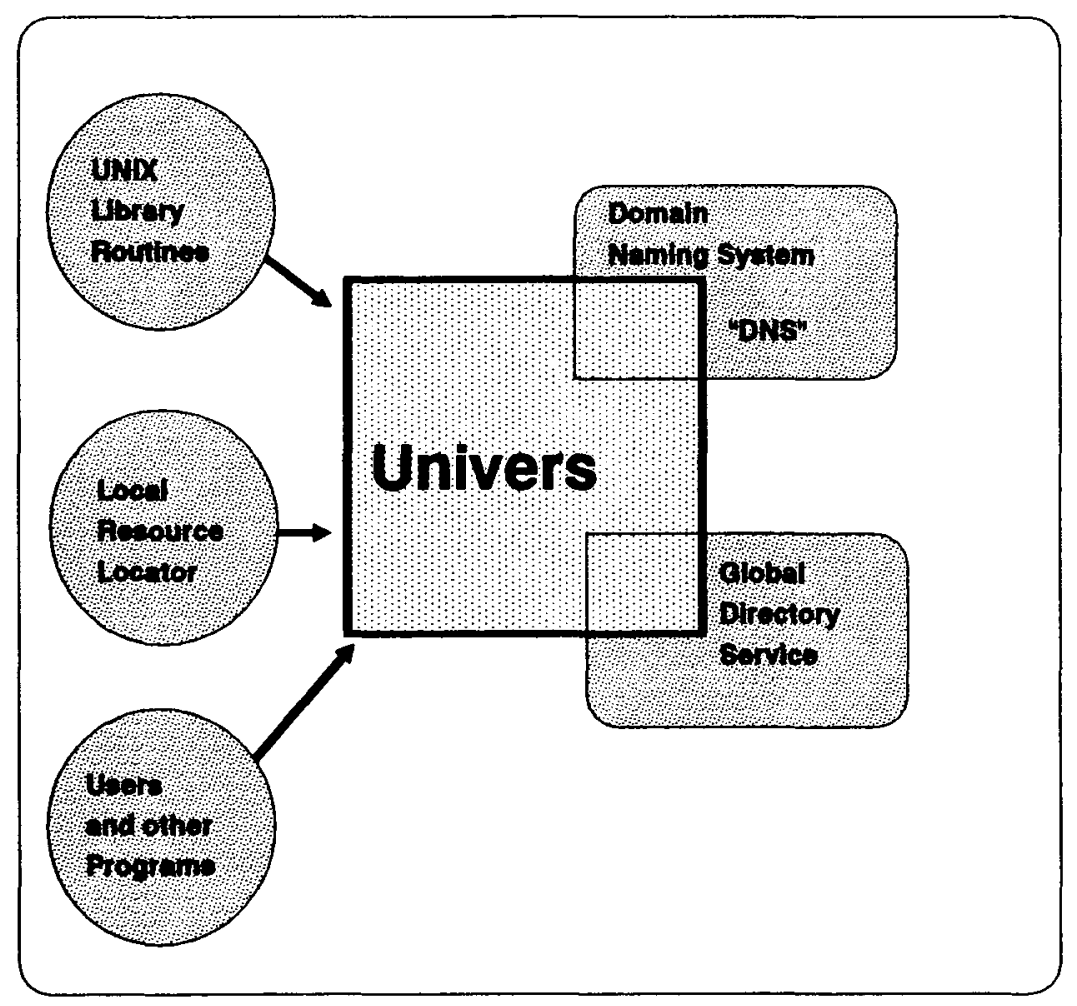

Figura 5.1 - Servidor Univers [BOW90] 


\section{Capítulo 6}

\section{Implementação do Núcleo Básico para um Servidor de Nomes Baseado em Atributos}

Este capítulo enfoca as fases de implementação do núcleo básico para um servidor de nomes baseado em atributos. São discutidas as motivações que levaram à escolha do modelo e detalham-se as características relevantes da implementaçāo do núcleo, considerando sempre como base teórica a descrição do modelo de nomeação baseado em atributos e a implementação do servidor de nomes "Univers", descritos no capítulo anterior. No decorrer deste capítulo, o núcleo do servidor de nomes implementado receberá a denominaçāo de "SENA" (SErvidor de Nomes baseado em Atributos).

\subsection{Introdução}

As características do "Univers", fazem dele um servidor de nomes diferente, que oferece vários mecanismos alternativos com suas funçōes claramente definidas e muitas das quais exclusivas (na bibliografia disponível revisada no capítulo 4 não há outras referências a servidores de nomes com características semelhantes).

Um servidor de nomes construído tomando como suporte o modelo de nomeação baseado em atributos, permite que os clientes, quer sejam processos do sistema ou mesmo usuários, consultem o servidor através de programas de nomeação, que podem ser definidos 
pelos clientes a partir das primitivas básicas; o servidor pode também ser consultado por meio de um conjunto de protocolos definidos segundo as necessidades do sistema computacional distribuído. Um dos maiores atrativos desse tipo de servidor, constitui o módulo gerador de atributos, através do qual é possível a obtençāo de informaçōes altamente precisas, já que essas informaçōes são atualizadas no momento da requisição.

Devido à dimensão e ao tempo necessário para a elaboração de um projeto completo de um servidor de nomes baseado em atributos, fez-se necessário limitar a implementação apresentada nesta dissertação, concentrando-se na construção de um núcleo básico, que ofereça as características, funçōes e principalmente a infra-estrutura a partir da qual possam-se desenvolver pesquisas para serviços de nomeação de mais alto nível.

O SENA foi construído como um servidor de nomes centralizado que visa atender os requisitos do sistema computacional distribuído em desenvolvimento no ICMSC-USP. Foi desenvolvido no LASD (Laboratório de Sistemas Digitais) sobre máquinas PC compatíveis com IBM (XT-AT 286,386). A linguagem de programação foi C, utilizando-se o compilador da Microsoft versão 6.0 [MIC90a, MIC90b].

O projeto e construção do SENA, apesar de sustentar sua base térica no trabalho do Prof. Bowman que descreve o desenvolvimento do "Univers" [BOW90], constitui um servidor original no que tange a essência estrutural e funcional, devido ao ambiente no qual foi desenvolvido, pois uma de suas finalidades funcionais é acoplar-se aos diversos módulos (servidores de arquivo, impressão, correio eletrônico e processamento paralelo, item 7.2) já implementados e em desenvolvimento no ICMSC-USP, como também foi necessário que sua estrutura e funcionamento fossem adequadas às ferramentas de trabalho disponiveis no projeto. Essas características adicionadas ao fato de que as máquinas PC do ambiente LASD trabalham sobre uma plataforma mono-usuário oferecida pelo sistema operacional MS-DOS (versão 5.0), destacam ainda mais as dificuldades acrescidas no desenvolvimento do SENA e a ampla diferença com seu similar (conceitualmente falando) "Univers".

Por outro lado, cabe destacar que o SENA administra e gerencia informaçōes do sistema SunOS disponível no ICMSC, compondo assim, um sistema de nomeação heterogêneo. No "Univers" não se faz referência a esse tipo de abordagem, o que torna o SENA um serviço de nomeação abrangente. 


\subsection{Considerações do Projeto}

O projeto e desenvolvimento do software visou satisfazer alguns conceitos fundamentais da engenharia de software [PRE87]:

-Modularidade: os quatro componentes principais do servidor, além da interface gráfica foram modularmente desenvolvidos, facilitando assim sua integraçāo, comunicação e futuras expansōes.

-Portabilidade: o software foi desenvolvido o mais independente possível do sistema operacional. Os módulos foram programados seguindo dentro do possível o $\mathrm{C}$ padrão.

- Manutenibilidade: no desenvolvimento foram tomadas várias decisōes de maneira a permitir atividades de manutençâo no decorrer da vida útil do servidor. A principal centro sua atenção na completa documentação do sistema.

$\mathrm{Na}$ implementação da interface com o usuário, foi dada especial ênfase aos aspectos relacionados com a facilidade de utilização e uma interação explicativa e amigável.

\subsection{Funções do Núcleo Básico do SENA}

O software desenvolvido para o SENA, foi dividido em sete componentes fundamentais:

1)Acesso e manipulaçâo da base de dados: este módulo contém o conjunto de rotinas de acesso e manipulação da base de dados.

2)Interpretador: composto pelo conjunto de rotinas que se encarregam da análise léxica e sintática do interpretador de comandos.

3)Modelo de Nomeação Baseado em Atributos: são os procedimentos e funçōes que implementam o modelo de nomeaçáo baseado em atributos. 
4)Gerador de Atributos: é o conjunto de rotinas que mantém periodicamente atualizados os atributos dinâmicos do SENA. Sendo que uma parte do gerador é executado em um ambiente SunOS e outra em um ambiente PC (no LASD), junto com as rotinas de comunicação entre esses dois ambientes.

5)Modelo cliente-senvidor: contém os procedimentos "Stubs" que permitem a comunicação do SENA com os clientes, usando como mecanismo de comunicação a troca de mensagens mediante RPC's (Chamadas de Procedimento Remoto), desenvolvida em [TRI91] e denominado Protocolo SPP (Servidor de Processamento Paralelo). Essas rotinas compōem o gerenciador de acesso do SENA. O modelo cliente-servidor está implementado no ambiente LASD (PC's).

6)Interface Gráfica no servidor: é constituída por vários procedimentos que permitem a comunicaçāo local dos usuários com o SENA, mediante o uso de janelas explicativas.

7)Cliente: o software do cliente $\varepsilon$ composto por uma interface grafica e pelos procedimentos "Stub's", que junto do protocolo SPP, permitem a comunicação com o SENA. O cliente requisita informações de mapeamento, isto $\varepsilon$, o servidor nesse caso atua como um servidor de nomes convencional. $O$ acesso remoto ao servidor não permite consultas baseadas nas funçōes primitivas ou programas de nomeação.

As funçōes e as principais ferramentas de programação utilizadas na construção de cada um desses módulos são descritos no decorrer dos seguintes sub-itens.

\subsection{Acesso e Manipulação da Base de Dados}

A base de dados do SENA, armazena as informações dos objetos gerenciados pelo servidor. Esses objetos sāo tanto os recursos externos (processadores, impressoras, usuários, etc.) que compõem o espaço de nomeação do servidor, quanto as "abstrações internas" ao servidor (contextos,tipos e funçōes). No decorrer desta dissertação todos os recursos externos serão referidos como objetos e quando houver referência aos tipos, contextos e funçōes, esses serão denominados de abstraçōes internas. 
Como discutido anteriormente, os recursos externos são representados por listas de atributos (nomes baseados em atributos) que, no armazenamento, foram limitadas para conter um máximo de vinte atributos por objeto, pois chegou-se à conclusão que: (a) para descrever um determinado objeto vinte atributos são suficientes para denotar suas características e (b) existem limitaçōes físicas relacionadas com a capacidade de memória secundária disponível. Dessa maneira os recursos externos do SENA são representados por estruturas de dados através de listas encadeadas de atributos (Figura 6.1a), onde cada atributo corresponde a um par < rótulo, valor > (Figura 6.1b).

Por outro lado, as estruturas de dados para as abstraçōes internas foram definidas através dos seguintes registros:

Registros de contextos:

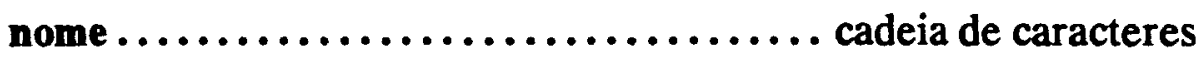

dono $\ldots \ldots \ldots \ldots \ldots \ldots \ldots \ldots . \ldots . \ldots$ cadeia de caracteres (usuário)

tipo $\ldots \ldots \ldots \ldots \ldots \ldots \ldots \ldots \ldots$.

ta\} tipo enumerado

Registros de tipos

nome ........................... cadeia de caracteres

lista de identificadores.$\ldots \ldots \ldots \ldots \ldots \ldots$ vetor de cadeias de caracteres

Registros de funçōes

nome ............................ cadeia de caracteres

programa de nomeação..$\ldots \ldots \ldots \ldots \ldots$ função composta

Foram desenvolvidos procedimentos e funções que manipulam a base de dados, podendo assim consultar, inserir, remover ou atualizar as informaçōes referentes aos objetos e abstraçōes armazenadas pelo servidor. Algumas dessas rotinas manipulam listas encadeadas de objetos. Onde cada objeto $\varepsilon$ um nome baseado em atributos, isto $\varepsilon$, uma lista de atributos (Figura 6.2).

Em função das rotinas do módulo de acesso e manipulação da base de dados manipular listas encadeadas de nós, onde cada n6 pode ser uma estrutura de atributo ou a 
estrutura de uma lista de atributos (um objeto), foi necessário implementar um conjunto de rotinas que gerencia o tratamento de listas encadeadas (Figuras 6.1b e 6.2).

m

(a) Estrutura de valor

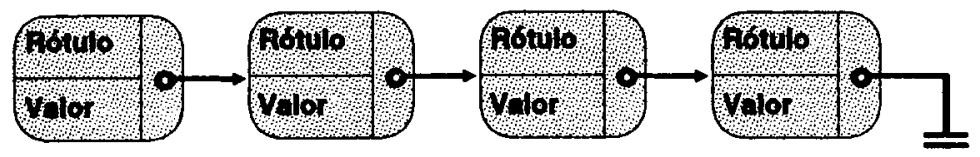

(b) Estrutura de objeto

Figura 6.1 - Nome Baseado em Atributos

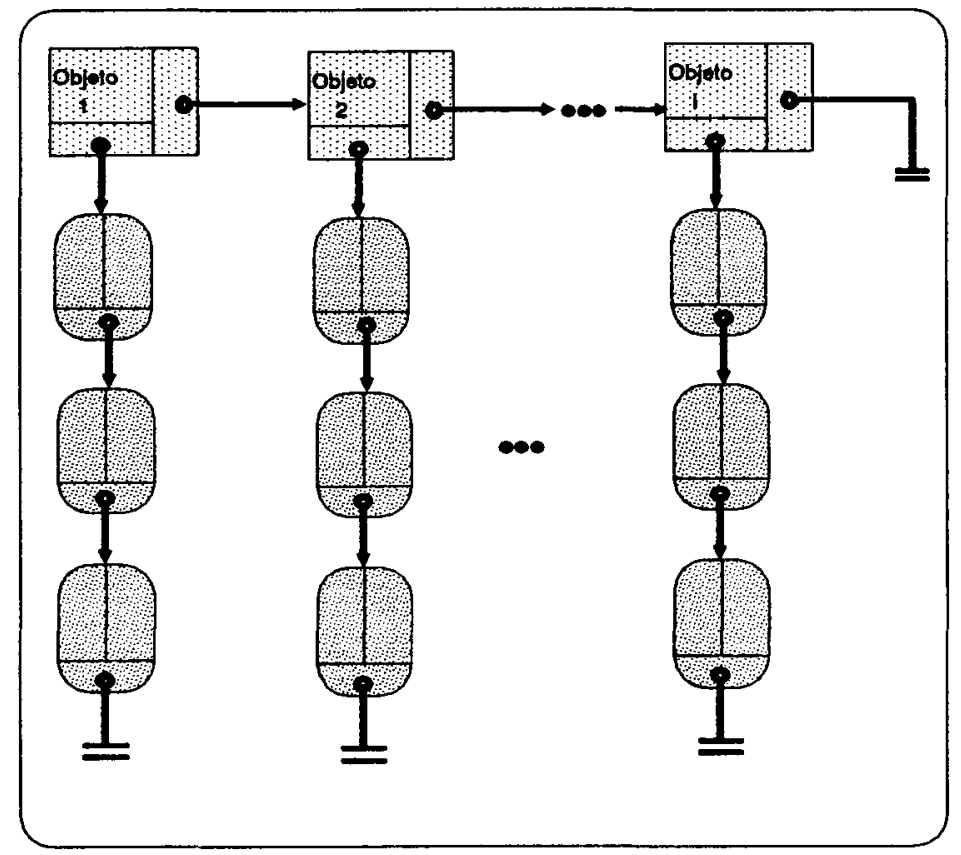

Figura 6.2 - Lista de Objetos 


\subsubsection{Interpretador}

"Um interpretador tem a funçāo de traduzir um programa fonte, decodificando suas unidades básicas (funçōes primitivas), para executá-las imediatamente" [KOW83].

A atividade de interpretação no SENA, tem como objetivo traduzir e executar linhas de comando de uma linguagem funcional [VEL92]. Assim surge a necessidade de se definir uma gramática computacional que foi denominada por LBA-Linguagem Baseada em Atributos, cuja definiçāo seguindo a "Forma Normal de Backus Estendida" (EBNF) encontra-se no apêndice A desta dissertação.

A LBA constitui o suporte formal do modelo de nomeaçâo baseado em atributos.

Foram definidos e desenvolvidos os dois componentes básicos de um interpretador [KOW83,NET87,SCH89]:

-Analisador Léxico: sua função é extrair e classificar os átomos de um programa (funções primitivas ou programas de nomeação) submetido à linguagem, ou seja, encarrega-se de mapear o texto fonte em outro texto formado pelos átomos que os símbolos componentes do texto fonte representam. As classes de átomos mais encontradas na LBA são: identificadores, palavras reservadas, números inteiros sem sinal, cadeias de caracteres, sinais de pontuação, etc.

-Analisador Sintático: engloba diversas funções de grande importância:

-Identificação de sentenças: o analisador sintático pode ser visto como um "aceitador" de cadeias, cujo conjunto forma a LBA.

-Deteç̧āo de erros de sintaxe: caso seja fornecida ao analisador uma cadeia que nāo pertença à LBA, este identifica a ocorrência, acusando a presença de erros de sintaxe através de uma mensagem impressa na tela, na qual o usuário do SENA é informado sobre o ponto de detecção do erro, o tipo de erro detectado e sobre a possível causa do erro.

-Comando de ativação do analisador léxico: em função do progresso do reconhecimento do texto fonte (linha de comando), o analisador sintático detecta a necessidade de novos átomos e ativa para tanto o analisador léxico. 
-Analisa a compatibilidade de parâmetros: quando são definidos os programas de nomeação em função das primitivas, pode-se fazé-lo utilizando variáveis, as quais no momento da ativação do programa seráo substituídos por identificadores, portanto o analisador sintático reconstr6i o programa de nomeação substituindo as variáveis pelos identificadores e alerta o usuário quando estes forem incompatíveis tanto em número, quanto em significado (item 6.3.3).

-Execução dos comandos: após a análise sintática ter sido concluída, o analisador sintático invoca as rotinas correspondentes para a execução do comando desejado, retornando os resultados ao módulo de interface gráfica para sua apresentação ao cliente.

Para o interpretador da LBA o texto fonte (comandos) corresponde às funções primitivas e aos programas de nomeação com seus respectivos parâmetros. Inclusive os valores de comparação dos atributos são interpretados segundo a definição formal da LBA, pois correspondem a expressões regulares descritas no item 5.2.1.

O interpretador do SENA em conjunto com as funçōes de acesso e manipulação da base de dados, permite que se façam consultas ao servidor utilizando-se os caracteres "*" e "?" conhecidos como "wildcards" (coringas), de tal forma que se possam buscar valores de atributos mediante a substituição de um ou mais caracteres pelo "wildcard" ? ou * respectivamente (seu uso $\epsilon$ similar ao feito no sistema operacional MS-DOS). Dessa maneira e possível procurar um objeto cujo nome seja xapac*, para o qual o SENA retornará todos os objetos cujos cinco primeiros caracteres sejam xapac; ou pode-se efetuar uma busca pelo nome xapac?ra, ao que o servidor responderá com todos os objetos que coincidam com todos os caracteres alfabéticos do nome sem importar qual é seu sexto caractere.

Essas características impostas ao interpretador, fazem com que este se torne um elemento extremamente útil e atrativo nas buscas sobre informações dos objetos. $O$ tipo de busca dependerá da função primitiva submetida ao servidor. 


\subsubsection{Modelo de Nomeação Baseado em Atributos}

As funçōes primitivas constituem as operaçōes básicas do Modelo de Nomeação Baseado em Atributos. O conjunto de primitivas proposto por Bowman em [BOW90], foi implementado seguindo seus conceitos funcionais, mas fazendo-se as devidas modificações de ordem sintática, de tal maneira a se manter uma correlação com a definição da LBA.

$\mathrm{Na}$ Tabela 6.1, são descritas as funções básicas implementadas no SENA, podendo-se observar na primeira coluna a sintaxe obrigatória de cada funçâo, sua lista de argumentos, as palavras e caracteres reservados e na segunda coluna os valores que cada uma das funçōes retorna junto com sua descrição funcional.

Devido à natureza funcional da LBA, as funçōes primitivas que retornam listas de objetos podem ser chamadas nas posições onde os argumentos exigem uma lista de objetos como parâmetro (em itálico). As cadeias (um ou mais caracteres) em negrito, apontam uma sintaxe obrigatória e as cadeias de caracteres entre os colchetes angulares $("<\ldots>$ "), correspondem a variáveis que devem ser do tipo especificado entre esses delimitadores ("<...>"). Dessa forma, a implementação das primitivas do SENA correspondem aos requisitos exigidos pelo modelo de nomeação baseado em atributos.

A título de exemplificaçāo apresenta-se a seguir como utilizar a função primitiva "Criar_Objeto", a qual permite a criação tanto de objetos quanto de abstrações internas e também descreve-se o funcionamento da interface do SENA:

-Para criar um novo tipo de nome usuário é necessário entrar a seguinte linha de comando:

\section{Criar_Objeto(type,usuário)}

o sistema requisitará a lista de rótulos necessários que identificam o tipo:

identificador 1 : nome

identifícador 2 : número do usuário

identificador 3 : diretório

identificador 4 : presença de mail 


\section{Identificador 5 : impressora permitida}

Dessa maneira foi definido o tipo usuário, cujas características são definidas inserindo os rótulos de seus atributos. Podem ser definidos até vinte rótulos necessários para cada tipo de objeto.

-Para criar um novo contexto para um usuário é necessário digitar:

\section{Criar_Objeto(context, usuário1, user)}

Assim é criado um contexto de nome usuáriol do tipo usuário. Os tipos de contextos podem ser: "application", "meta", "session", "system" ou "user" (item 5.2.1). Nos contextos criados é possivel adicionar e remover objetos utilizando-se as funçōes respectivas descritas na Tabela 6.1.

-Para criar um novo programa de nomeaçăo, isto $\varepsilon$, uma nova funçāo, requer-se a seguinte linha de comando:

\section{Criar_Objeto(function, Get_Processor)}

a seguir o SENA pedirá a definiçāo do programa de nomeaçāo Get_Processor em funçāo das primitivas disponíveis, para o qual o usuário poderia digitar a seguinte funçāo composta:

\section{Selecionar(Selecionar_Contexto(máquinas),arquitetura, = ,\$1)}

As variáveis definidas pelos usuários deverão ser representadas pelo sinal " $\$$ " seguido de qualquer cadeia alfanumérica, podem ser definidas zero ou mais variáveis nos lugares dos parâmetros necessários. Quando o usuário deseja utilizar o programa de nomeação, nesse caso, Get_Processor, ele deverá fornecer o nome da função seguido, entre parênteses, do tipo de arquitetura que ele requisitar, por exemplo: 


\section{Get_Processor(68020)}

Os valores entre parênteses são substituidos pelas definições de variáveis feitas na definição do programa de nomeação.

Para esse exemplo o servidor retornará todos os nomes baseados em atributos de todas as máquinas cuja arquitetura é 68020 .

-Finalmente, para criar um novo objeto (recurso externo) na base de dados do SENA é necessãrio digitar a linha de comando:

Criar_Objeto(object)

o sistema solicitará a digitação de todos os atributos do objeto que se está definindo:

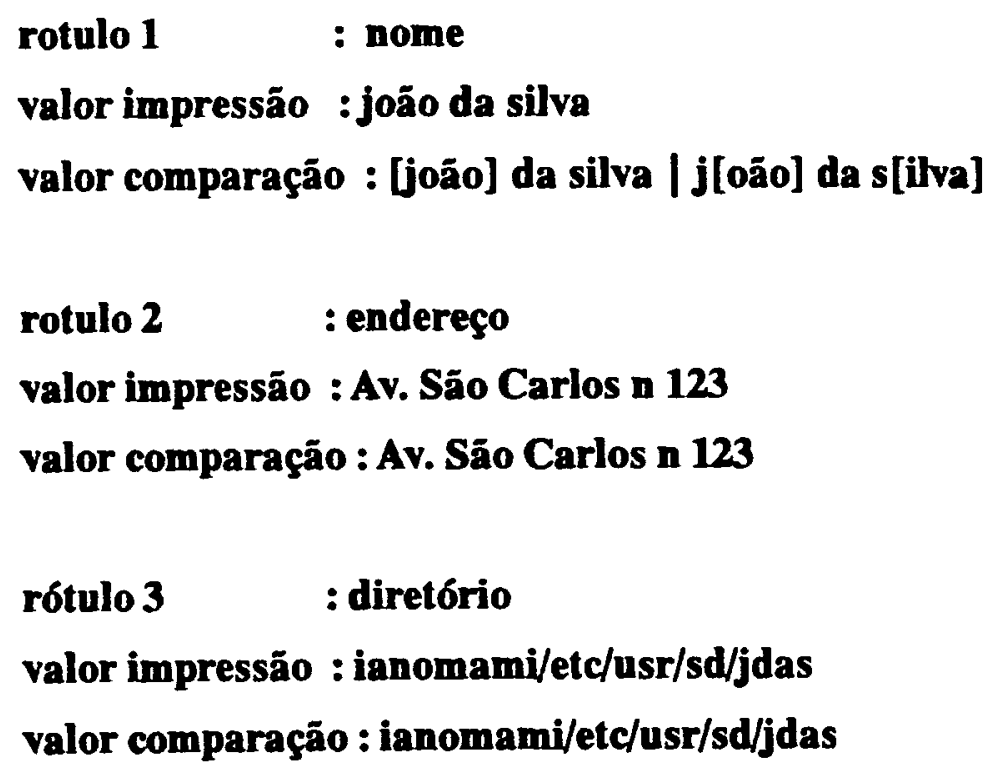

$\mathrm{Na}$ inserçāo, um objeto será aceito pelo SENA, se e somente se, tiver sido definido um tipo para esse objeto. Se existir o tipo, o objeto será automaticamente associado ao tipo e inserido na base de dados. 
Quando for digitado o valor de comparação, o interpretador analisará a expressão fornecida pelo usuário, de forma a verificar sua sintaxe; se estiver errada, o usuário será alertado e deverá digitar novamente um valor de comparaçâo correto.

Um objeto inserido $\epsilon$, automaticamente, colocado em um "meta" contexto de nome "geral".

Quando um objeto é removido da base de dados, este é removido de todos os contextos aos quais pertence, bem como também da relação interna do tipo que 0 caracteriza. Pode-se ainda adicionar e remover atributos dos objetos definidos na base de dados.

Além das funçōes de criação, destruição, adicionamento e remoção de atributos e objetos do SENA, encontram-se disponíves funções primitivas que selecionam objetos de acordo com as características definidas pelo cliente. Podem-se selecionar todos os objetos de um determinado tipo ou contexto e ainda selecionar dentro dessa lista de objetos, aqueles que satisfaçam as características desejadas pelo cliente.

Um cliente que deseja encontrar os usuários cujo primeiro nome começa com a letra " $C$ ", pode submeter a seguinte composiçāo de funçōes primitivas:

\section{Preferir(Selecionar_Tipo(usuário),nome, c*)}

para o qual o sistema retornará todos os usuários cuja letra inicial do seu primeiro nome é "C".

Cabe ressaltar que para o interpretador $\varepsilon$ indiferente o uso de letras maiúsculas ou minúsculas nas funções, programas de nomeação, identificadores ou palavras reservadas, já que ele converte e trata internamente as cadeias de caracteres em minúsculas. 


\begin{tabular}{|c|c|}
\hline 1-Diferenciar(lista_objetos, < rótulo >) & $\begin{array}{l}\text { A partir da lista de objetos, retorna uma sub-lista cujos } \\
\text { atributos tenham o rótulo dado. }\end{array}$ \\
\hline $\begin{array}{l}\text { 2-Selecionar(lista_objetos, }<\text { rótulo,op_rel,valor }>\text { ) } \\
\text { op_rel }=\{=,<,>,<=,>=,<>\}\end{array}$ & $\begin{array}{l}\text { A partir da lista de objetos, retorna uma sub_lista de } \\
\text { objetos que satisfaçam o operador relacional. }\end{array}$ \\
\hline 3-Projetar(lista_objetos, < rótulo >) & $\begin{array}{l}\text { A partir da lista de objetos, retorna o atributo de cada } \\
\text { objeto que tenha o rótulo especificado. }\end{array}$ \\
\hline 4-Preferir(lista_objetos, < rótulo,valor $>$ ) & $\begin{array}{l}\text { A partir da lista de objetos, retorna uma sub-lista que } \\
\text { satisfaça o par < rótulo,valor >. }\end{array}$ \\
\hline 5-Selecionar_Tipo(lista_objetos, < nome_tipo >) & $\begin{array}{l}\text { A partir da lista de objetos, retorna a sub-lista que seja } \\
\text { do tipo < nome_tipo }>\text {. }\end{array}$ \\
\hline 6-Selecionar_Contexto(<nome_contexto $>$ ) & $\begin{array}{l}\text { Retorna a lista de objetos que sâo do tipo } \\
<\text { nome_contexto }>\text {. }\end{array}$ \\
\hline 7-Adicionar_Atributo(lista_objetos, atribute) & Adiciona o atributo a todos os objetos da lista. \\
\hline 8-Remover_Atributo(lista_objetos,atribute) & Remove o atributo de todos os objetos da lista. \\
\hline 9-Adicionar_Objeto(< nome_contexto >,object) & Adiciona um objeto ao contexto < nome_contexto $>$. \\
\hline 10-Criar_Objeto(object) & Cria um objeto. \\
\hline $\begin{array}{l}\text { 11-Criar_Objeto(context, < nome_contexto >,tipo) } \\
\text { tipo }=\{\text { user,system,aplication,session,meta }\}\end{array}$ & $\begin{array}{l}\text { Cria um contexto de nome <nome_contexto }>\text { e de } \\
\text { tipo específico. }\end{array}$ \\
\hline 12-Criar_Objeto(function, < nome_funçāo >) & $\begin{array}{l}\text { Cria um programa de nomeaçāo de nome } \\
\text { <nome_função }>\text {. }\end{array}$ \\
\hline 13-Criar_Objeto(type, < nome_tipo >) & Cria um tipo cujo nome $\epsilon<$ nome_tipo $>$. \\
\hline 14-Remover_Objeto(object, < nome_contexto >) & Remove um objeto do contexto < nome_contexto>. \\
\hline 15-Remover_Objeto(context, < nome_contexto >) & $\begin{array}{l}\text { Remove o contexto <nome_contexto > da base de } \\
\text { dados. }\end{array}$ \\
\hline 16-Remover_Objeto(function, < nome_funçāo >) & $\begin{array}{l}\text { Remove o programa de nomeação chamado } \\
<\text { nome_função }>\text {. }\end{array}$ \\
\hline
\end{tabular}

Tabela 6.1 - Funçōes Básicas do SENA 


\subsubsection{Gerador de Atributos}

O gerador de atributos do SENA, tem como objetivo principal manter atualizados os atributos dinâmicos (discutido no item 5.2.2) dos objetos pertencentes ao ambiente SunOS do ICMSC, tornando estas informações disponíveis aos usuários do ambiente LASD.

A base de dados do SENA, armazena dois tipos de objetos do ambiente SunOS: os seus usuários e suas estações de trabalho SunOS.

Assim, o gerador de atributos encontra-se dividido em três módulos: o primeiro denominado analisador de atributos, encarrega-se da monitoraçāo das informações dos objetos do ambiente SunOS; o segundo permite a ligação dos dois ambientes, permitindo a transferência das informações do ambiente SunOS para o PC; e o terceiro, cuja função é atualizar a base de dados em função das informações transferidas do ambiente SunOS (Figura 6.3).

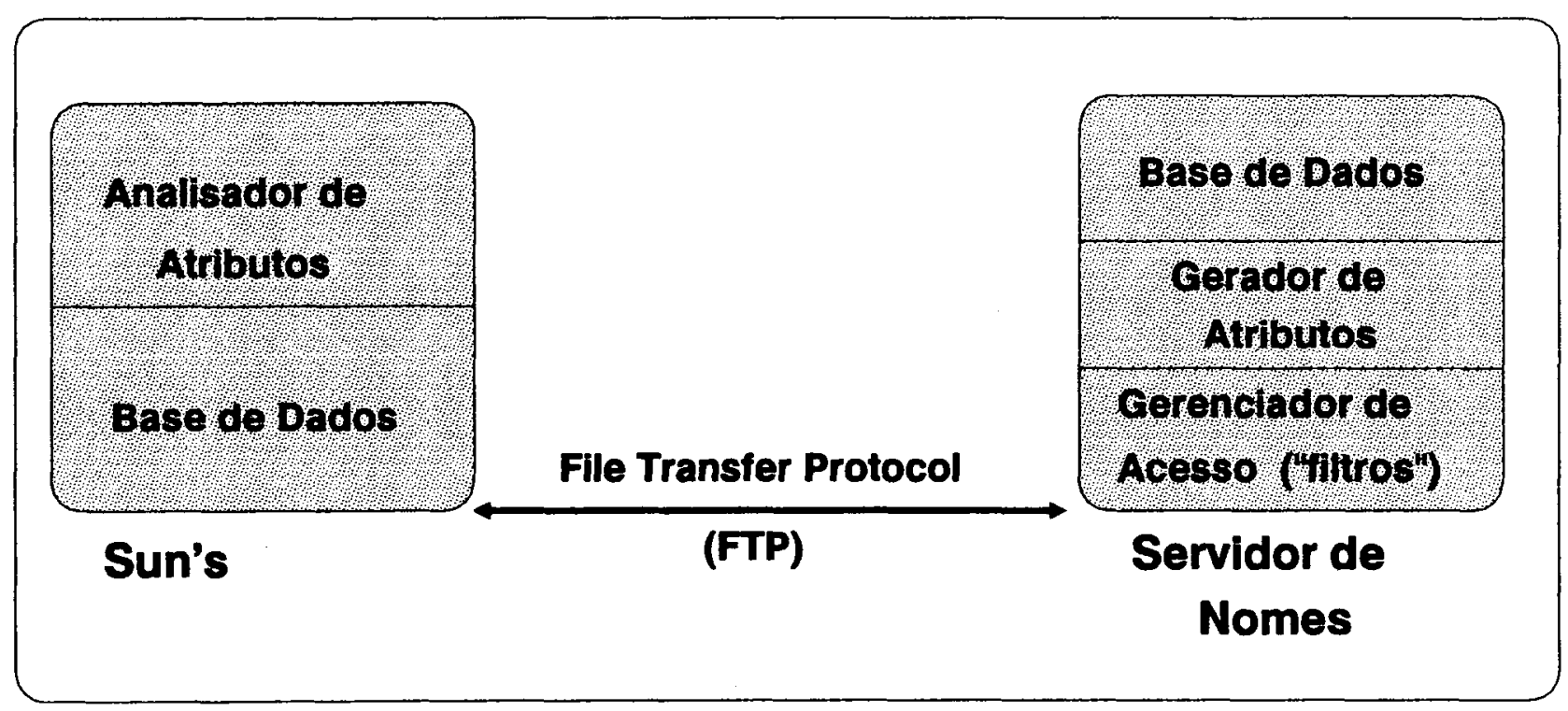

Figura 6.3 - Gerador de Atributos 


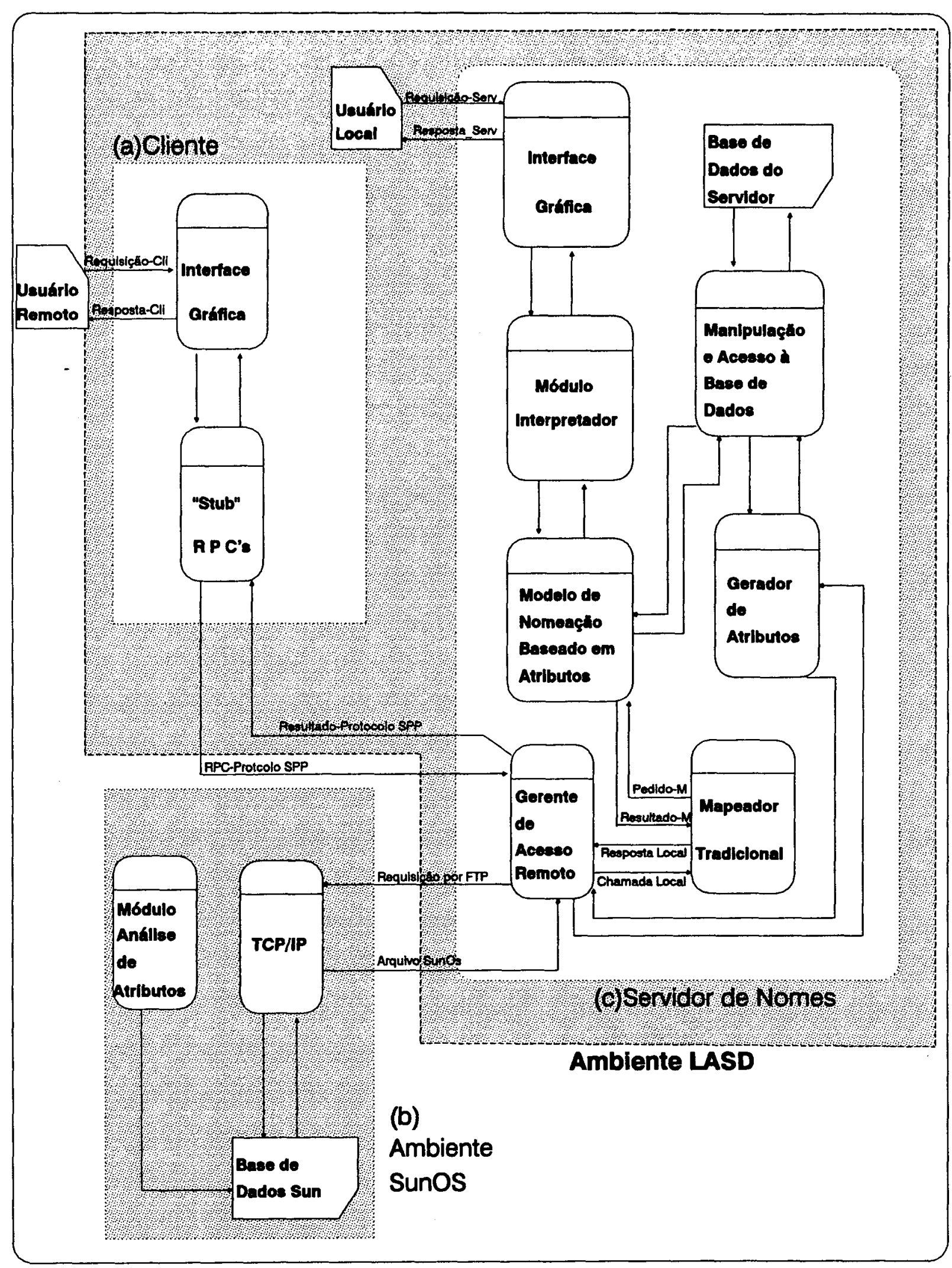

Figura 6.4 - Fluxo de Dados no SENA 


\subsubsection{No Ambiente SunOS}

O conjunto de rotinas desenvolvidas para esse módulo, resultam em um processo que pode ser executado em "background" (é um processo cujo dono é um super-usuário do ambiente SunOS's, que é mantido em execução indefinidamente), o qual, através de chamadas ao sistema, atualiza uma base de dados local, que por sua vez é periodicamente transferida ao ambiente LASD (Figura 6.4b). As informações dinâmicas de cada objeto que interessam a esse modulo são descritas a seguir:

a)Para os usuários são atualizados os atributos que se referem às máquinas que estão utilizando, se eles têm mensagens não lidas recebidas pelo correio eletrônico e há quanto tempo eles nâo ingressam no sistema SunOS.

b)No caso das máquinas, é atualizado o atributo referente ao dono ou donos (usuários), de todas as estações de trabalho.

Essa monitoração é feita mediante duas chamadas ao sistema: "finger e rusers" [SUN91c,SUN91d].

Também mantém-se atualizado o conjunto de usuários. Uma vez que novos individuos podem ser incorporados ao ambiente SunOS, assim quando forem transferidos os dados, serão transferidos os novos usuários do ambiente SunOS, permitindo a atualização da base de dados do SENA.

Esse módulo pode ser futuramente expandido de tal forma que mais tipos de informaçōes, como por exemplo a carga de trabalho das máquina da rede, sejam mantidos e atualizados. Isso requer um aprofundamento no estudo das chamadas ao sistema SunOS, bem como também podem ser incluídas algumas novas funçōes que são de uso exclusivo dos super-usuários da Sun.

\subsubsection{No ambiente LASD}

Essas rotinas correspondem a um módulo do SENA, cujas funçōes são (Figura 6.4c): 
1)Invocar periodicamente os procedimentos que transferem os arquivos do ambiente SunOS para o ambiente LASD. Para transferir os dados, o sistema dispōe de uma lista contendo a relaçāo das máquinas do ambiente SunOS, de modo a garantir a transferência dos dados, caso alguma das máquinas esteja fora de operação. Isso visa o contínuo funcionamento do servidor, mantendo um maior nível de independência com o ambiente SunOS e garantindo a disponibilidade das informações no SENA.

2)Analisar as informaçōes trazidas e proceder à atualização da base de dados do SENA. Os dados transferidos devem ser formatados de acordo com as estruturas utilizadas no SENA e procede-se então à atualizaçāo dos atributos dos objetos correspondentes.

Assim, o analisador de atributos é acionado no ambiente LASD e se mantém em constante execuçāo no ambiente SunOS, visando manter a base de dados com informaçōes o mais próximas possíveis da realidade dos objetos do ambiente SunOS.

\subsubsection{Ligação do ambiente SunOS com o LASD}

O ambiente SunOS e o ambiente LASD são interligados pelo SENA. Para a transferência dos dados (as informaçōes) utiliza-se o protocolo TCP/IP para máquinas PC (XT e AT compatível com IBM). Esse protocolo é de fácil utilizaçāo e relativamente eficiente para esse tipo de tarefa [RIB92]. São bastante difundidas duas implementações de domínio público do protocolo TCP/IP para PC (XT e AT compatível com IBM):

-O KA9Q(TCP/IP) Intemet Packet, desenvolvido para redes de comutação por pacotes para rádio amador, podendo também ser utilizado por outras redes de comutação por pacotes. $O$ pacote contém os protocolos FTP (File Transfer Protocol), TELNET, e SMTP (Simple Mail Transfer Protocol) [FTP89,KAR91]. 
- TCP/IP NCSA (National Center for Supercomputing Applications) para IBM-PC, o qual oferece acesso interativo e não interativo de um IBM-PC ou compatível, a hospedeiros Telnet sobre redes TCP/IP. Os hospedeiros Telnet são computadores que possuem um endereço IP (Internet Protocol) conhecido pela configuraçāo instalada no PC. NCSA Telnet é um padrão DARPA (Defense American Research Project Agency) Telnet com características adicionais que melhoram o processamento local do PC [NCS91]. Utliza-se este protocolo na comunicação do SENA com o ambiente SunOs.

Foi escolhida a implementação do protocolo TCP/IP considerando-se os seguintes fatores:

a)Através desse protocolo é possível efetuar um acesso não interativo aos hospedeiros Telnet no ambiente SunOS.

b)O sistema SunOS utiliza o conjunto de protocolos TCP/IP.

c)A transferência de dados do ambiente SunOS para o LASD possibilita uma maior independência entre os dois ambientes.

d)O protocolo de transferência de arquivos "FTP" especifica um "time-out" de espera para estabelecer a conexão com o hospedeiro. Dessa forma o SENA pode continuar em funcionamento mesmo que todo o sistema SunOS não esteja operando [NCS91].

\subsubsection{Comunicação Cliente-Servidor}

O modelo cliente-servidor foi implementado com o auxlio do protocolo de comunicação SPP (Servidor de Processamento Paralelo) desenvolvido por Trindade em [TR191]. Esse mecanismo de comunicação, junto com os procedimentos "Stub" desenvolvidos compõem o Gerenciador de Acesso do SENA (Figura 6.5). 


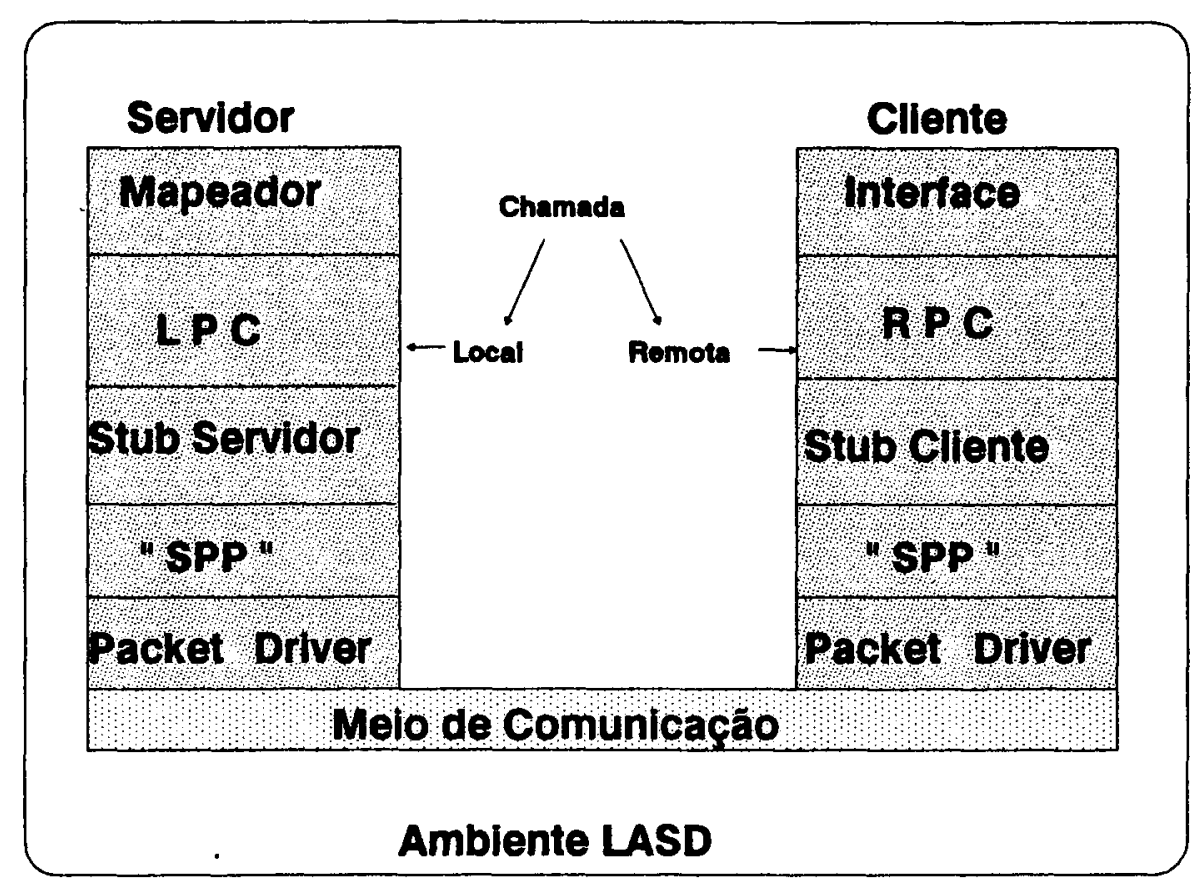

Figura 6.5 - Modelo Cliente-Servidor

\subsubsection{Protocolo SPP [SAN93]}

O protocolo SPP implementa a comunicação de processos através de troca de mensagens mediante a implementação de RPC's (Chamadas de Procedimento Remoto), seguindo a semântica "at-most-once" (no máximo uma vez, item 3.3.1) discutida em [WIL87].

O SPP utiliza como mecanismo de acesso ao meio o Packet Driver [CLA89] e suas requisiçōes ocupam um único pacote Ethernet, onde as chamadas aninhadas não são permitidas. No caso de erros no cliente ou no servidor, uma mensagem é enviada ao cliente e a primitiva é abortada.

A semântica "no máximo uma vez" é controlada pela "seqüência de requisiçāo", representada por uma variável binária (assume valores zero ou um) associada a cada primitiva inicializada no cliente e no servidor. A seqüência de requisição no servidor é complementada após a execução de uma primitiva. No cliente a seqüência é complementada após o recebimento da resposta. 
Quando o servidor recebe um pedido, verifica se a seqüência de requisição para a primitiva solicitada coincide com a esperada. Se isso acontecer, a primitiva é executada, caso contrário, o pedido é ignorado e é enviada a última resposta da primitiva, que ficou armazenada em uma tabela de sessão do servidor (Figura 6.6).

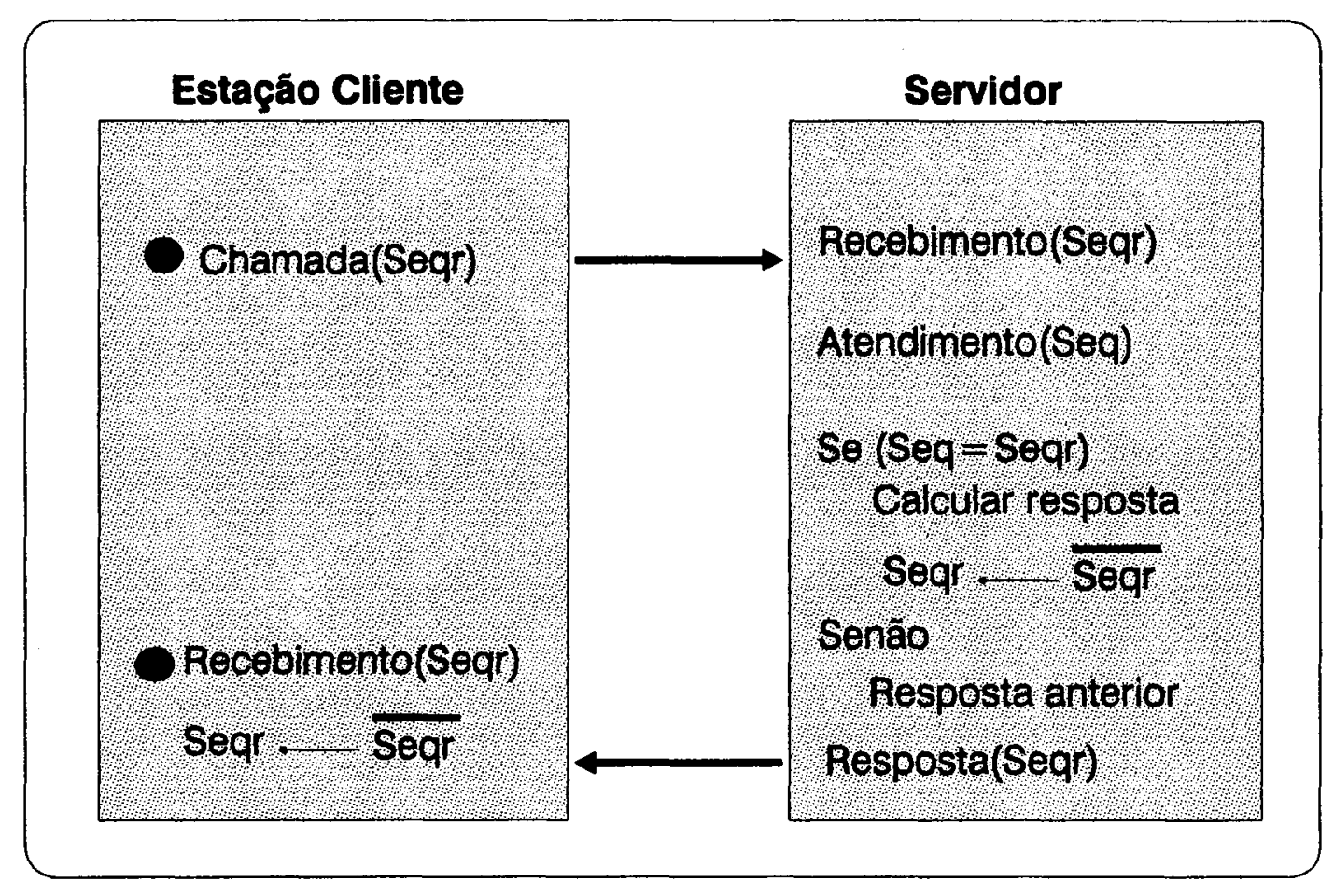

Figura 6.6 - Seqüência de Requisição

\subsubsection{Funções do Cliente e do Servidor}

O SENA pode operar tanto em modo local quanto em modo remoto (Figuars 6.4a e 6.4b). No modo local são atendidas requisições feitas por meio das funçōes primitivas ou através de programas de nomeação. Aqui cabe ressaltar que devido à comunicação ser feita diretamente entre o usuário e SENA, não existem procedimentos "stub". No modo remoto o SENA trabalha como um mapeador de informações convencional. Os dois modos de operação do SENA são descritos a seguir: 


\section{Acesso Remoto ao SENA}

No modo remoto o servidor trabalha como um servidor de nomes tradicional, ou seja, ele tem a função de mapear informações com base nas requisiçōes efetuadas pelo cliente. No cliente, o usuário pode requisitar informaçōes para dois tipos de objetos: usuários e máquinas. Os usuários podem ser tanto usuários do ambiente SunOS como do LASD, no caso das máquinas as informaçōes sāo restritas às estações de trabalho SunOS.

a)Para requisitar informações das estaçōes de trabalho SunOS o usuário tem à sua disposição um ambiente de janelas, no qual escolhe o nome da máquina, mediante o uso das setas do teclado. Após a seleção do nome o usuário recebe uma nova janela onde ele escolhe o tipo de informação sobre determinada máquina; essas informaçōes podem ser: o endereço internet da estação, seu tipo de monitor, dimensōes do monitor, verificar a presença de disco, o usuário ou usuários da máquina e a arquitetura do seu processador.

b)Se o usuário opta por obter informações dos clientes, ele deve escolher essa opção na janela principal do cliente. Então o sistema solicitará a digitação do nome do usuário, a seguir o sistema apresenta uma janela contendo as informações que podem ser requisitadas ao servidor. Essas informaçōes compreendem: o número de identificação que usuário tem, se ele tem correio eletrônico não lido, a máquina ou máquinas que ele está utilizando, seu diretório (corresponde ao grupo ao qual pertence dentro do ICMSC). Pode ainda requisitar o endereço ou telefone do usuário em questão. Caso o usuário não esteja registrado no SENA, é apresentada uma mensagem para o cliente.

Dessa maneira demonstra-se que um servidor de nomes implementado sobre um modelo de nomeaçāo baseado em atributos, pode funcionar como um mapeador convencional, da maneira como muitos sistemas distribuídos e sistemas operacionais de rede estão tradicionalmente operando. 


\section{Acesso Local ao SENA}

No caso do acesso local, o usuário tem a facilidade de manipular o espaço de nomes, podendo criar seu proprio serviço de nomeação através da criação de programas de nomeação ou utilizando as próprias funçōes primitivas. $O$ usuário local do servidor inicialmente deverá ser o gerente do sistema, sobre o qual descansam as responsabilidades de gerenciamento do espaço de nomes.

Na operaçáo local do SENA o usuário também recebe auxílio de janelas. Assim o usuário pode escolher três op̧̧ões na janela principal:

1)Requisitar informações através das funções primitivas; aqui o usuário escolhe a função desejada com o auxilio das setas do teclado e a seguir o sistema apresenta uma janela com a sintaxe necessária requerida pela funçāo escolhida, a qual deverá ser digitada em uma outra janela que aparece simultaneamente. Dependendo da funçāo primitiva, o sistema solicita, sempre mediante o uso de janelas, a digitação dos dados requeridos como parte dos argumentos das funçōes. Essas funçōes são interpretadas e se não apresentarem erros serão executadas e seus resultados serão mostrados ao usuário.

2)O usuário pode requisitar informaçōes através de programas de nomeação; após a escolha na janela principal, o sistema solicita a digitação do programa de nomeaçāo, que após a interpretação e execuçāo apresentará os resultados correspondentes.

3)Finalmente o usuário pode escolher que o servidor atenda consultas remotas de outros clientes. O servidor entrará no modo de execução remota e conforme os usuários nas máquinas clientes ingressem no sistema mediante um "login", o servidor atenderá às requisiçōes efetuadas. 


\subsubsection{Interface Gráfica}

Como descrito no funcionamento do cliente e do servidor, $e$ utilizado um sistema de janelas interativas, que permite que os usuários tanto no cliente como no servidor, escolham suas opçōes com o auxilio das setas do teclado.

O sistema de janelas pode ser analisado logicamente como uma cascata, na qual após efetuar-se uma determinada escolha pressionando a tecla $<$ ENTER $>$,apresenta uma outra janela para dar continuidade às escolhas necessárias para requisitar informações ao servidor. Caso o usuário deseje voltar uma janela atrás, isto pode ser feito pressionando-se a tecla $<$ ESC $>$. Se for pressionada a tecla $<$ ESC $>$ na janela principal, tanto no cliente como no servidor, o programa finaliza sua execução.

Os erros cometidos por parte do usuário e as mensagens de requisiçōes que não forem computadas com sucesso, são sempre impressos na tela, tentado esclarecer ao máximo, a possível origem da falha da requisição ou do uso errado do sistema.

De modo a não prejudicar o desempenho do sistema, muitas das rotinas fazem chamadas diretas a interrupçōes da BIOS ("Basic Input Output System") e foram implementadas em C.

Na figura 6.4 observa-se o fluxo de informaçāo ao qual o SENA é submetido tanto no cliente, no servidor e no ambiente SunOS, bem como seus principais modulos funcionais e a comunicaçào em alto nível entre esses elementos.

\subsection{Considerações Finais}

A implementação do SENA concentrou-se na construção da infra-estrutura básica de um servidor de nomes baseado em atributos, a partir da qual podem ser feitas extensōes e melhoramentos no serviço de nomeação.

O núcleo de um servidor de nomes baseado em atributos foi implementado de acordo com as necessidades e restriçōes próprias do contexto de desenvolvimento. A implementação utiliza como base teórica os conceitos definidos por Bowman na construção 
do "Univers" [BOW90].

A implementação do SENA foi feita em um ambiente mono-usuário sobre sistema operacional MSDOS, diferente do contexto no qual o servidor "Univers" foi desenvolvido, pois esse servidor foi projetado para um ambiente multiusuário e sua implementação foi baseada em estações de trabalho Sun, executando o SunOS (Unix- Like), portanto podendo fazer uso dos diversos recursos que esse ambiente oferece, como por exemplo todos os protocolos de comunicação TCP/IP, "StubGen ou stub generator" (gera stubs para chamadas de procedimentos remotos), a própria característica de ser um sistema multi-usuário, entre outros.

Tentou-se adaptar ao nosso ambiente um sistema gerador de atributos, fazendo uso das características disponíveis no ambiente SunOS. O SENA não garante que as informaçōes obtidas pelo gerenciador de atributos sejam consistentes com a realidade, mas coloca à disposição dos usuários (no ambiente LASD) várias informaçōes que podem ser importantes, sem precisar ingressar no ambiente SunOS.

O projeto e implementação do SENA visou a construção completa de todos os módulos necessários para o correto funcionamento do núcleo do servidor de nomes, como foi descrito passo a passo e m6dulo por m6dulo neste capítulo. 


\section{Capítulo 7}

\section{Conclusões}

Este capítulo encerra esta dissertação apontando as conclusōes e contribuições obtidas após a implementação do SENA. Apresenta uma série de propostas para trabalhos futuros e a crítica bibliográfica.

\subsection{Conclusões e Contribuições do Trabalho}

Bowman, em [BOW90], destaca que a implementaçāo de um servidor de nomes baseado em atributos apresenta as seguintes características relevantes no desenvolvimento de servidores de nomes para ambientes distribuídos:

a)Esse tipo de servidor deixa a responsabilidade de implementação do sistema de nomeação nas mãos dos programas de nomeação. Assim, um cliente pode carregar o servidor de nomes com os tipos, funçōes e contextos que precisa para implementar seu sistema de nomeação particular.

b)Explora quatro idéias básicas:

1)Associa um conjunto de atributos a cada objeto e dá suporte a consultas baseadas na combinação de atributos. Assim, o servidor não se limita a mapeamentos lógicos-físicos (nome-endereço) e sim a consultas contendo 
qualquer informação conbecida pelo cliente para cada objeto identificado e não somente seu nome e endereço.

2)Aceita programas de nomeação arbitrários como consultas, contrastando com servidores de nomes convencionais que só dão suporte a um pequeno número de consultas.

3)Permite ao usuário definir novos tipo de objetos. Os usuários podem isolar classes de objetos de seu interesse sobre os quais queiram operar.

4)Fornece um mecanismo explícito para a manutenção de atributos de objetos contidos em uma base de dados. Manter servidores de nomes atualizados é um dos problemas mais difíceis enfrentados pelos projetistas de sistemas de nomeação.

Essas conclusōes ajustam-se plenamente à características obtidas no desenvolvimento do SENA.

A experiência e os conhecimentos obtidos no decorrer da implementação do SENA, bem como no desenvolvimento desta dissertação, levam às seguintes conclusōes:

-Obteve-se um mecanismo de nomeação moderno, que atende às tendências atuais para pesquisas de sistemas de nomeação, uma vez que fornece um suporte para a descrição de nomes mediante um conjunto de atributos; fornece também um sistema de nomeaçāo de recursos em sistemas heterogêneos. Essas características satisfazem os requisitos exigidos por Comer em [COM89], para as linhas de pesquisas na área de servidores de nomes.

-Contribui com um mecanismo de atualizaçāo de informaçōes (Gerador de Atributos), que visa satisfazer um dos grandes problemas dos servidores de nomes. Sua implementação demonstra que mediante o uso de ferramentas de comunicação disponiveis, $\in$ possível manter um certo grau de consistência entre as informaçōes reais dos recursos do sistema e os seus correspondentes armazenados na base de dados. Existem várias modificaçōes que deverão ser feitas no gerador de maneira a melhorar a consistência das informaçōes, essas modificaçōes sāo amplamente discutidas na seção seguinte. 
-Permitiu integrar dois ambientes heterogêneos: o ambiente SunOS e o ambiente LASD (baseado em PC's), de tal forma que o servidor de nomes pode gerenciar os espaços de nomes dos dois ambientes, possibilitando que usuários requisitem informações mantidas em um sistema Unix a partir de um sistema MS-DOS.

-O fato do servidor ter sido desenvolvido no ambiente LASD, diferente do ambiente do "Univers" (o qual até agora é o único servidor de nomes baseado em atributos disponível na literatura), destaca uma nova linha de pesquisa nesse campo. Levando em consideração as diferenças salientadas no item 6.1, é fácil observar que apesar do SENA ter sido desenvolvido seguindo o modelo de nomeação baseado em atributos e espelhando-se na construçāo do Univers, ele tem uma estrutura própria, originada em funçāo do meio no qual foi criado.

-A construção de todos os módulos do SENA permitiu a obtenção de um domínio total do sistema e de suas partes integrantes, o que permitirá a fácil integraçāo de novas características visando complementar as funçōes do servidor.

-Devido principalmente a considerações de tempo, alguns aspectos importantes foram deixados de lado na construção do SENA:

1)O gerenciador de acesso, como pode ser visto em 5.2.2, além de controlar a comunicaçāo do servidor com os clientes, encarrega-se dos aspectos de segurança do servidor. Essas funçōes controlam o acesso ao servidor permitindo e limitando o uso de certos objetos e abstrações do servidor. Essas características podem ser futuramente acrescentadas e são discutidas em 7.2.

2)O usuário que deseja manipular as funçōes básicas oferecidas pelo modelo de nomeação baseado em atributos, deve operar diretamente no próprio servidor. Seria extremamente desejável que os usuários tivessem acesso remoto a essas funçōes desde a máquina cliente. Assim, surge a necessidade de se definir um Protocolo de Serviço de Nomeação (PSN), também discutido na seção seguinte (item 7.2). 
O núcleo para um servidor de nomes baseado em atributos "SENA", discutido nesta dissertaçāo de mestrado, tem como finalidade enriquecer uma área de pesquisa pouco descrita na literatura, de tal forma a encorajar pesquisas futuras e servir como material de consulta para novos empreendimentos.

Atualmente, as pesquisas nesse campo têm como finalidade construir mecanismos de nomeação capazes de integrar espaços de nomeação heterogêneos, aproveitando dessa maneira os sistemas já existentes. Pesquisas na área de sistemas de nomeação baseadas em atributos podem contribuir na solução desse problema universal e devem ser abordadas, bem como patrocinadas, já que apresentam grandes expectativas futuras, como pôde ser visto no decorrer desta dissertação.

\subsection{Proposta de Trabalhos Futuros}

A seguir são listadas algumas sugestōes para continuidade deste trabalho:

a)Implementação dos mecanismos de segurança, de maneira a complementar as funçōes do SENA. Deve-se projetar uma camada de software que verifique e valide o ingresso dos usuários no sistema. A seguir o sistema deverá verificar: quais são os recursos computacionais (objetos) e quais as abstrações que esse usuário pode manipular e que tipo de acesso ele pode fazer nesses recursos ou abstraçōes. Todas essas informaçōes podem ser definidas dentro do próprio nome baseado em atributos, como sendo mais uma característica do objeto definido. As estruturas de dados definidas no SENA foram projetadas de tal forma que essas funções possam ser acrescentadas (Figura 7.1a).

b)Desenvolver a camada de transporte para o SPP, permitindo a transferência de dados cujo tamanho seja maior do que a capacidade do pacote Ethernet. Definir a semântica de comunicação das primitivas básicas do SENA. Dessa forma torna-se possível que os usuários tenham acesso às funçôes do modelo de nomeação baseado em atributos, a partir de uma máquina cliente. Assim, seria definido um protocolo de comunicação para o SENA que poderia ser denominado PSN ('Protocolo de 
Serviço de Nomeação") (Figura 7.1b).

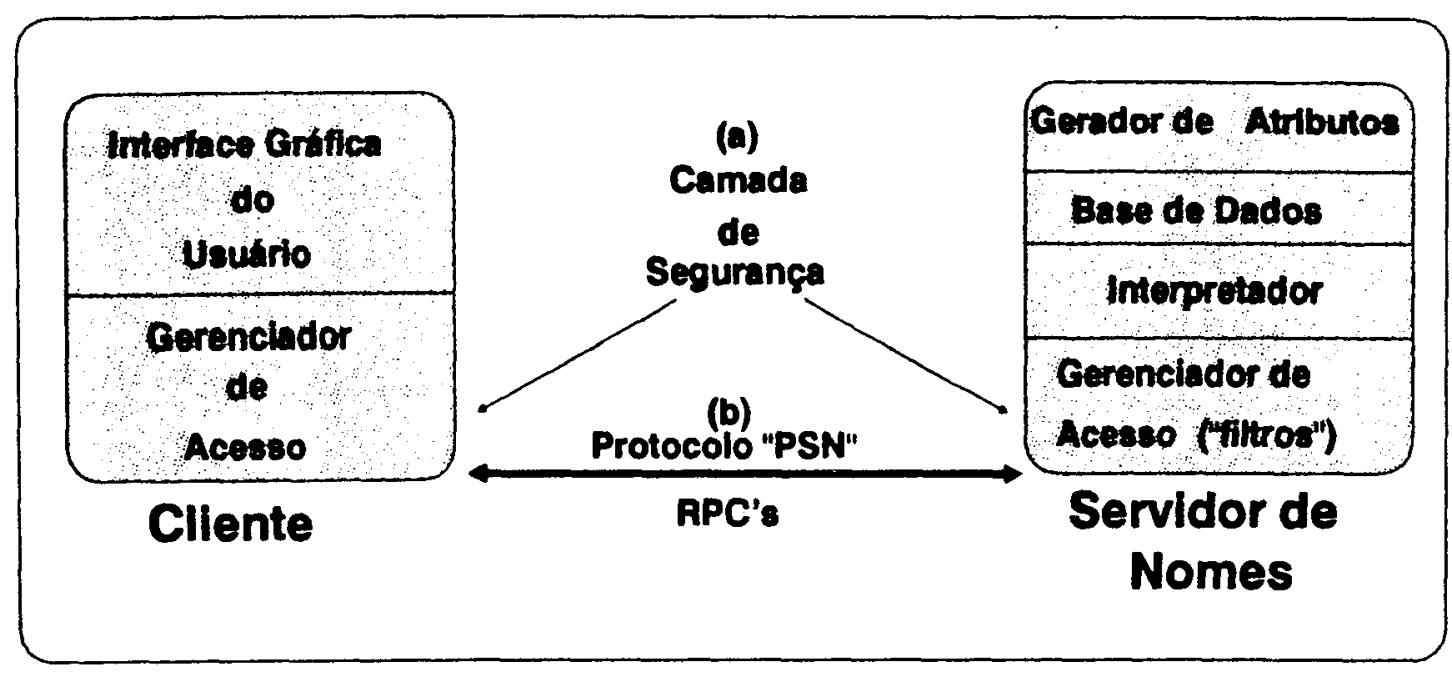

Figura 7.1 - Segurança e Comunicação

c)Com as características dos itens anteriores acrescentadas ao SENA, torna-se extremamente interessante implementar serviços de nomeação de mais alto nível, como por exemplo:

c.1)Construir um servidor de diretório, que poderia atender às características de nomeação do sistema Unix.

c.2)Desenvolver sistemas de nomeação de página branca e de página amarela. Existe na bibliografia um exemplo de um serviço de página branca baseado em atributos "Profile" (item 4.6) [PET88], implementado sobre o "Univers", que auxiliaria seu projeto e implementação (Figura 7.2).

d)O servidor de nomes poderia interagir com os servidores implementados pelo Grupo de Sistemas Distribuídos e Programaçāo Concorrente do ICMSC-USP: Servidor de Processamento Paralelo [TRI90], Servidor de Correio Eletrônico [RIB92], Servidor de Impressão [FUR92] e futuramente com os servidores de arquivos que atualmente estāo em desenvolvimento. Funcionaria como um mapeador convencional de elementos de um domínio lógico em um domínio físico e vice-versa. 


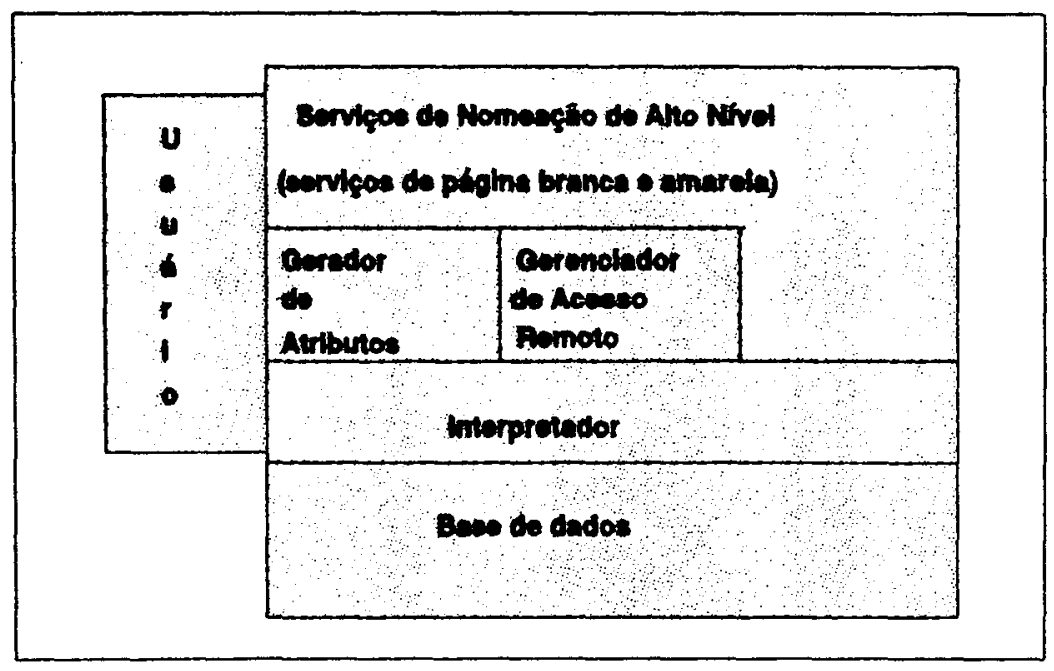

Figura 7.2 - Serviços de Alto Nível

e)O processo pertencente ao Gerador de Atributos que é executado no ambiente Sun, poderia ser acionado a partir do ambiente LASD. Para isso estâo disponíveis no ambiente SunOS duas chamadas ao sistema: o "portmapper" que relaciona um processo com uma porta de comunicação e o "inetd", que fica monitorando as portas de comunicação, quando chegar algum pacote ele analisa o pacote, relaciona com um processo e o executa. $O$ acionamento desde o ambiente LASD pode ser feito pelo "rshell". Cabe pesquisar a disponibilidade do comando rshell dentro do pacote de comunicaçāo Telnet para PC (XT e AT compativel com IBM) [SUN90, SUN91a, SUN91b].

f) O SENA poderia ser transportado para o ambiente SunOS e fazer uso de todos os recursos disponíveis nesse ambiente. $O$ interpretador pode ser gerado com auxilio de Lex e do Yacc [KER84]. O protocolo de comunicação PSN seria definido sobre um ou mais protocolos TCP/IP (UDP,TCP) e mediante a implementação de Chamadas de Procedimento Remoto através do "StubGen" (gerador de stubs) [SUN90].

g)Em função da LBA ser uma linguagem funcional que manipula lista de objetos, outra opção poderia ser implementar o interpretador usando a linguagem Scheme [JON86,DYB87] que $\varepsilon$ um dialeto de Lisp ("List Processing") e encontra-se 
disponível no ambiente SunOS. Essa abordagem corresponde à última versão do "Univers".

b)Pode-se implementar um mecanismo tolerante a falhas que garanta o funcionamento constante do SENA (item 3.4), dentro do ambiente LASD. A replicaçāo do servidor poderia ser a técnica implementada, que em conjunto com PSN, poderia compor um mecanismo de tolerância a falhas bastante atrativo.

i)Memórias "Cache" correspondem a uma alternativa para melhorar o desempenho dos módulos do SENA. Especificamente seria extremamente útil implementar uma das técnicas especificadas no item 3.4. Um "Cache" no cliente ou no servidor que mantenha as informações mais utilizadas pelos clientes do SENA, poderia melhorar o desempenho do servidor [YEO93].

\subsection{Crítica bibliográfica}

A revisão bibliográfica apresentada no decorrer desta dissertação tem alguns tópicos que merecem destaque:

\section{Do estudo de redes locais}

A bibliografia apresentada sobre o assunto é vasta. Há um consenso entre os autores sobre as técnicas de acesso ao meio de transmissão, as topologias básicas apresentadas e sobre os principais conceitos básicos de redes locais [CLA78, STA84a, STA84b, GIO86, MOU86, TAN89].

As redes locais demonstram ser amplamente utilizadas devido a facilidade de interconexāo de dispositivos, permitindo o compartilhamento de recursos de custo elevado e o compartilhamento de dados entre várias máquinas [CLA78, STA84a, STA84b, MOU86]. 


\section{Do estudo de sistemas distribuídos}

A literatura disponível é bastante diversificada no que diz respeito à definiçăo de sistema distribuído. Vários autores definem sistemas distribuídos, destacando o conceito de transparência, onde os detalhes de implementação e utilização são invisiveis ao usuário, apresentando-lhe o sistema como um único computador [TAN85, COU88, MUL89, TAN92]. Entretanto, Kirner e Mullender, em [KIR88, MUL89], consideram a tolerância a falhas como outro requisito indispensável para um sistema distribuído.

Tanenbaum e Coulouris, em [TAN85, COU88, TAN92], apresentam os principais modelos arquiteturais: estação de trabalho/servidor, banco de processadores e minicomputador, sendo que Coulouris acrescenta duas combinações desses modelos, o modelo integrado e o hrbrido. Existe também um consenso na bibliografia nos conceitos cliente/servidor e pode-se observar que o mecanismo de comunicação mais utilizado é a troca de mensagens mediante a implementação de RCPs (chamadas de procedimento remoto) [TAN85, COU88, MUL89, COM93].

\section{Do estudo sobre servidores de nomes e serviço de nomeação}

Os conceitos básicos sobre serviço de nomeação e servidores de nomes encontram-se na literatura de uma forma muito particionada. Encontram-se poucas publicaçōes inteiramente dedicadas ao assunto [BOW90, CHE84, CHE89, PET88, SHE86, TER86, ZAT92]. Cabe ressaltar que Mullender, em [MUL89], define a importância e as principais funções de um sistema de nomeação no contexto de sistemas distribuídos.

Cheriton, em [CHE84,CHE89], cita alguns fatores que afetam o projeto do servidor de nomes e Tanenbaum, em [TAN85], classifica os servidores de nomes em centralizados e distribuídos.

Existe um consenso na bibliografia nos principais conceitos relacionados com nomes externos e identificadores únicos, embora muitos autores usem nomes diferentes para os mesmos conceitos [TER86, SIN91b, ZAT92].

No que diz respeito à resoluçāo de nomes, Cheriton, em [CHE84], classifica esse conceito baseado na dificuldade que o serviço de nomeação encontra em escolher onde será feita a resolução do nome e onde será feita a operação de localização do objeto. Por outro 
lado Sinha e Tanenbaum, em [SIN91b, TAN85], citam vários métodos propostos e usados para o gerenciamento do espaço de nomes. Quanto às convençōes de nomeação, Oppen e $\mathrm{Su}$, em [OPP83, SU82], as classificam em nomeaçāo absoluta e relativa.

Dos exemplos analisados cabe ressaltar os sistemas de nomeação baseados em atributos [PET88, BOW90, COM89, VEL93], os quais oferecem um mecanismo de bloco de construção sobre o qual vários serviços podem ser implementados (serviço de página branca, página amarela, etc.) e que Comer, em [COM89], ressalta como as pesquisas mais promissoras na área de servidores de nomes. 


\section{Referências Bibliográficas}

[ASC91] ASCMANN, H.R., et al. Alphorn: a remote procedure call enviroment for fault-tolerant, heterogeneus, distributed systems, IEEE Micro, p.16-67, outubro, 1991.

[BOW90] BOWMAN M., Peterson L.L., Yeatts A. Univers : an attributed-based name service, Software-Practice and Experience, v.20, n.4, p.403-24, abril, 1990.

[BRY93] BRYCE, C., et al. Models and Paradigms for Distributed Systems Structuring in the Fifh ACM SIGOPS European Workshop, Operating Systems Review, ACM Press, v.27, n.2, abril, 1993.

[BUX85] BUX,W., et al.The Token Ring., Em Hutehinson, D.; Mariani, J.; Shepherd, D. Local Area Networks: an advanced course. Berlim, Springer, p.36-63, 1985. (Lectures Notes in Computer Science, 184).

[CLA78] CLARK, D.; POGRAN, K.T.; REED, D.P.. An Introduction to Local Area Networks. Proceedings of the IEEE, v.66, n.11, p.1497-517, novembro, 1978.

[CLA89] CLARCSON University, User Documentation for Packet Driver Collection, version $1.09,1989$.

[CHA90] CHAMPINE, A.G.; GEER, D.; RUH N.W.. Project Athena as a distributed computer system, IEEE Computer, p.40-51, setembro, 1990.

[CHE84] CHERITON,R.D. e MANN,P.T.. Uniform Access to Distributed Name Interpretation in the $\mathrm{V}$ System, The 4th Int Conf Dist Comp Sys IEEE, 
p.290-7, 1984.

[CHE88] CHERITON, R.D.. The V Distributed System, Communications of the ACM, v.31, n.3, p.314-33, março, 1988.

[CHE89] CHERITON, R.D. e TIMOTHY, M.P.. Decentralizing a global naming service for improved perfomance and fault tolerance, $A C M$ Transactions on Computer Systems, v.7, n.2, p.147-83, maio, 1989.

[COM89] COMER, D.E. and PETERSON, L.L.. Understanding Naming in Distributed Systems, Distributed Computing, v.3, p.51-60, 1989.

[COM91] COMER, D.E.. Internetworking with TCP/IP: principles, protocols and architecture, Englewood Cliffs, Prentice-Hall, v.1, 1991.

[COM93] COMER, D.E. e STEVENS, D.L.. Internetworking with TCP/IP - Client-Server Programming and Applications, BSD socket version, Englewood Cliffs, Prentice-Hall, v.3, 1993.

[COU88] COULOURIS, G.F. e DOLLIMORE, J.. Distributed Systems: concepts and design, Wokingham, Addison-Wesley, 1988.

[DYB87] DYBVING, R.K.The Scheme programming language, Englewood Cliffs, Prentice-Hall, 1987.

[FTP89] FTP Software In, PC/TCP Packet Driver Specification, version 1.09, US, FTP Software Inc. 1989.

[FUR92] FURQUIN, R.C.. Servidor de Impressão para um ambiente Computacional Distribuŕdo, Tese de Mestrado, ICMSC-USP, São Carlos SP, 1992.

[GIO86] GIOZZA, W.F. et al.. Redes Locais de Computadores: tecnologia e aplicaçōes, São Paulo, McGraw-Hill, 1986.

[HUG93] HUGHES, L. Object Identification in the Lego Kernel, Sofware-Practice and Experience, v.23, n.4, p.405-18, abril, 1993. 
[JON86] JONATHAN, R, e WILLIAM. C.. Revised Report on the Algorithmic Language Scheme, Artificial Intelligence Laboratory of MIT, Technical Report n. 174, outubro, 1986.

[KAR91] KARN, P.. NET User Reference Manual, NOS Version, junho, 1991.

[KER84] KERNIGHAM, B.W. e PIKE R.. The Unix Programming Enviroment, Englewood Cliffs, Prentice-Hall, p.233-88, 1984.

[KIR88] KIRNER, C. e MENDES, S.B.T.. Sistemas Operacionais Distribuídos: aspectos gerais e análise de sua estrutura, Rio de Janeiro, Campus, 1988.

[KOW83] KOWALTOWSKI, T.. Implementação de Linguagens de Programaçāo, Ed. Guanabara Dois, Rio de Janeiro, 1983.

[LUN82] LUNN, K. Reliable File Storage in a Distributed Computing System. Tese de Doutorado (PhD), Universidade de Keele, U. K. , março, 1982.

[MIC90a] MICROSOFT C. Reference Manual, Microsoft Corporation, USA, 1990.

[MIC90b] MICROSOFT C. Advanced Programming Techniques, Microsoft Corporation, USA, 1990.

[MOU86] MOURA, J.A.B. et al. Redes Locais de Computadores, protocolos de alto nível e avaliação de desempenho, São Paulo, McGraw-Hill, 1986.

[MUL89] MULLENDER, S.J. (ed).. Distributed Systems, New York, Addison-Wesley, 1989.

[NCS91] NCSA Telnet for IBM PC version 2.3, University of Illinois at Urbana-Champaign, junho, 1991.

[NET87] NETO, J.J.. Introdução à Compilação, LTC-Livros Técnicos e Científicos Editora S.A., Rio de Janeiro, 1987. 
[OPP83] OPPEN, D.C. e YOGEN K.D.. The Clearinghouse : a decentralized agent for locating named objects in a distributed environment, $A C M$ Transactions on Office Information Systems, v.1, n.3, p.230-53, julho, 1983.

[OUS88] OUSTERHOST K.J.; CHERENSON R.A., et al, The Sprite Network Operating System, IEEE Computer, p.23-30, fevereiro, 1988.

[PET88] PETERSON L.L.. The Profile Naming Service, ACM Transactions on Computer Systems, v.6, n.4, p.341-64, novembro, 1988.

[PRE87] PRESSMAN, R.S.. Sonware Engineering - A Practicioner's Approach, McGraw-Hill, Nova York, 1987.

[RIB92] RIBEIRO, R.. Servidor de Correio Eletrônico em Ambiente Computacional Distribuído, Tese de Mestrado, ICMSC-USP, São Carlos SP, 1992.

[SAN90] SANTANA, R.H.C.. Perfomance evaluation of LAN-based file servers, Tese de Doutorado (PhD), Universidade de Southampton, U.K., 1990.

[SAN93] SANTANA, M.J., et al. Um Protocolo Dedicado para Acesso Remoto a Transputers via TDS, $X X$ SEMISH, Florianópolis, v.1, p.38- 46, setembro, 1993.

[SHE86] SHELTZER B.A.; LINDELL R.; POPEK J.G.. Name Service Locality and Cache Design in a Distributed Operating System, Proc 6th Int'L Conf Dist Comp Sys IEEE, p.515-22, 1986.

[SCH89] SCHILDT, H.. Building your own C Interpreter, Dr. Dobb's Joumal, p.38-49 110-22, agosto, 1989.

[SIN91a] SINGHAL, M. e CASAVANT, T.L.. Distributed Computing Systems, IEEE Computer, p.12-5, agosto, 1991.

[SIN91b] SINHA K.P., et al. The Galaxy Distributed System, IEEE Computer, p.34-41, agosto, 1991. 
[SMO85] SMOCH, J.F., et al. The Ethernet. Em: Hutchison, D.; Mariani, J.; Shepherd, D.

Local Area Networks: an advanced course. Berlim, Springer, p.1-35, 1985 (Lecture Notes in Computer Science, 184).

[SOL82] SOLOMON, M.; LANDWEBER, H.L.; NEUHENGEN, D.. The CSNET Name Server, Computer Networks, v.6, p.161-72, 1982.

[STA84a] STALLINGS, W.. Local networks, ACM Computing Surveys, v.16, n.1, p.3-41, março, 1984.

[STA84b] STALLINGS, W.. Local networks, an introduction. New York, Macmillan, 1984.

[SU82] SU, Z.S. e POSTEL J.. The Domain Naming Convention for Internet User Applications, Request for Comments, n.819, agosto, 1982.

[SUN90] SUN MICROSYSTEMS, INC. Network and Communications, California, 1990.

[SUN91a] SUN MICROSYSTEMS, INC. SPARC. Deskset Reference guide, California, SUN MICROSYSTEMS, 1991.

[SUN91b] SUN MICROSYSTEMS, INC. SPARC. Sun system user's guide, California, SUN MICROSYSTEMS, 1991.

[SUN91c] SUN MICROSYSTEMS, INC. SPARC. Reference Manual, v.1, 1991.

[SUN91d] SUN MICROSYSTEMS, INC. SPARC. Reference Manual, v.2, 1991.

[TAN85] TANENBAUM, A.S. e VAN RENESSE, R.. Distributed Operating Systems, ACM Computing Surveys, v.17, n.4, p.419-70, dezembro, 1985.

[TAN87] TANENBAUM, A.S.. Operating Systems: design and implementation, Englewood Cliffs, Prentice-Hall 1987.

[TAN89] TANENBAUM, A.S.. Computer Networks, 2 ed, Englewood Cliffs, Prentice-Hall, 1989. 
[TAN92] TANENBAUM, A.S.. Modern Operating Systems, Englewood Cliffs, Prentice-Hall, 1992.

[TER86] TERRY D.B.. Structure-free Name Management for Evoluing Distributed Environments, Proc 6th Int'L Conf Dist Comp Sys IEEE, p.502-8, 1986.

[TER87] TERRY, D.B.. Caching Hints in Distributed Systems, IEEE Transactions on Software Engineering, v.SE-13, n.1, p.48-54, janeiro, 1987.

[TRI91] TRINDADE, Jr.O.. Servidor de Processamento Paralelo Baseado em Transputers, Tese de Doutorado, IFQSC-USP, São Carlos SP, 1991.

[VEL92] VELASCO, O.H.S.. LBA: Uma Linguagem Baseada em Atributos, Relatónio Técnico N-1, ICMSC-USP, outubro, 1992.

[VEL93] VELASCO, O.H.S. e SANTANA, M.J.. Servidor de Nomes Baseado em Atributos, XIX Conferencia Latinoamericana de Informática e Investigación Operativa, v.3, p.383-400, Buenos Aires, agosto, 1993.

[WEL86] WELCH, B. e OUSTERHOST, J.. Prefix Tables: A simple mechanism for locating files in a distributed system, Proc 6th Int'L Conf Dist Comp Sys IEEE, p.184-9, 1986.

[WIL87] WILBUR, S.. Building Distributed Systems with Remote Procedure Call, Software Engeneering Joumal, p.148-59, setembro, 1987.

[YEO93] YEO, A.K.; ANANDA A.L.; KOH, E.K. A Taxonomy of issues in Name Systems Design and Implementation, Operating Systems Review, v.27, n.3, p.4-18, julho, 1993.

[ZAT92] ZATTI, S., et al. Naming and Registration for IBM distributed systems, IBM Systems Joumal, v.31, n.2, p.353-80, 1992. 


\section{Bibliografia}

BIRREL, A. e NELSON, B.J.. Implementing Remote Procedure Calls, ACM Transactions on Computer Systems, v.2, n.1, p.39-59, fevereiro, 1984.

CAMARĀO, P.C.B.. Glossário de Informática, Rio de Janeiro, LTC- Livros Técnicos e Científicos Editora Ltda., 1988.

GANE, C. e SARSON, T.. Análise Estruturada de Sistemas, Rio de Janeiro, LTC-Livros Técnicos e Científicos Editora S.A., 1983.

HOROWITZ, E. e SAHNI, S.. Fundamentos de Estruturas de Dados, 3 ed., Rio de Janeiro, Campus, 1987.

JAMSA, K. Microsof C: Dicas, Segredos e Truques, São Paulo, Makron Books, 1992.

KERNIGHaM, B.W. e RTTCHIE, D.M.. C a Linguagem de Programação, 3 ed.,Rio de Janeiro, Campus, 1987.

TENENBAUM, A.M.; LANGSAM, Y.; AUGENSTEIN, M.J.. Data Structures using C, Englewood Cliffs, Prentice-Hall, 1990.

VELASCO, O.H.S.. Servidor de Nomes para Sistemas Computacionais Distribuídos, Monografia do Exame Geral de Qualificaçāo, ICMSC- USP, Brasil, agosto, 1992. 


\section{Apêndice A}

\section{Gramática LBA (Linguagem Baseada em Atributos)}

Uma gramática é definida pela seguinte quadrupla $G=(\mathrm{Vn}, \mathrm{Vt}, \mathrm{P}, \mathrm{S})$, onde

Vn são os valores não terminais.

Vt são os valores terminais.

S é o simbolo inicial.

P são as produçōes permitidas na gramática.

Para a definiçāo da gramática LBA são utilizados alguns meta- caracteres:

| Elementos separados por "|" são alternativas.

- Da mesma forma que caracteres em negrito englobam texto literal.

; Inicia um comentário que termina no final da linha.

$::=$ Sinal de atribuição, o lado esquerdo é não terminal e o direito pode ser Vn ou Vt.

\{A\} Um ou mais valores $(\mathrm{Vn})$ separados por vírgula. 
A gramática LBA é definida da seguinte maneira:

Vn: nomes mneumônicos entre colchetes angulares ("< > ).

Vt: cadeias em negrito ou entre '.

$S:<\mathbf{L B A}>$

P : produções listadas abaixo.

$<$ LBA $>::=<$ função > 'In' ; |n significa < Enter >

< função > :: = < função_primitiva > $\mid$ < função_definida >

< função_primitiva > ::= < função_retorna_lista_objetos > | <função_sem_retorno>

< função_retorna_lista_objetos > :: =

Selecionar (<lista_objetos $>$ ', $<$ par > ', $<$ par_op $>$ ', $<$ par $>$ )

|Prefírir(<lista_objetos $>$ ', $<$ par $>$ ','<par $>$ )

|Diferenciar(<lista_objetos $>$ ', $<$ par $>$ )

|Selecionar_Tipo(<lista_objetos $>$ ', $<$ par $>$ )

|Selecionar_Contexto( $<$ par $>$ )

|Projetar(< lista_objetos >', < par >)

< funções_sem_retorno > ::=

Adicionar_Atributo( $<$ lista_objetos $>$ ', $<$ atributo $>$ )

|Remover_Atributo(<lista_objetos $>$ ', $<$ atributo $>$ )

|Criar_Objeto(<parâmetros_criar >)

|Remover_Objeto(< parâmetros_remover) 


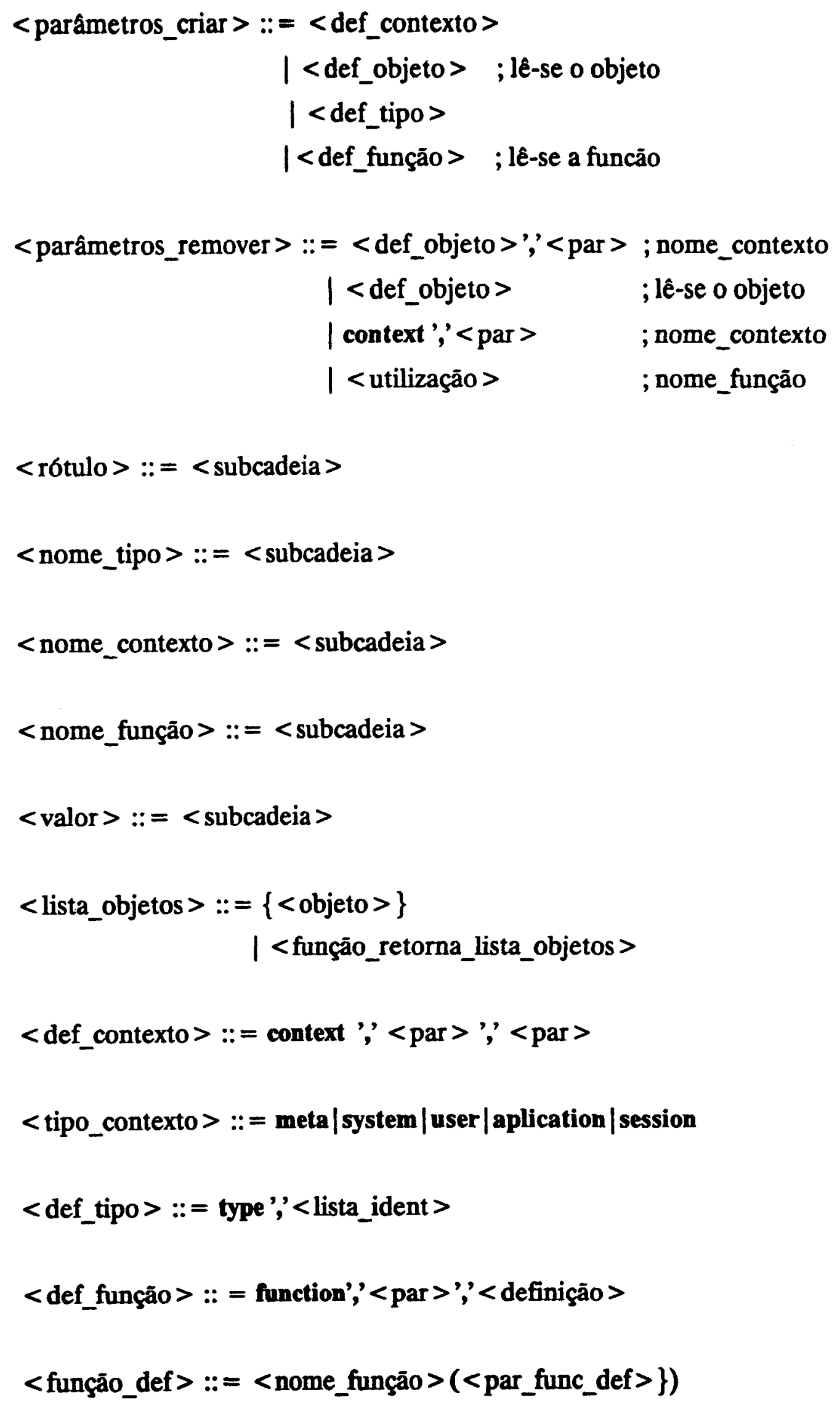




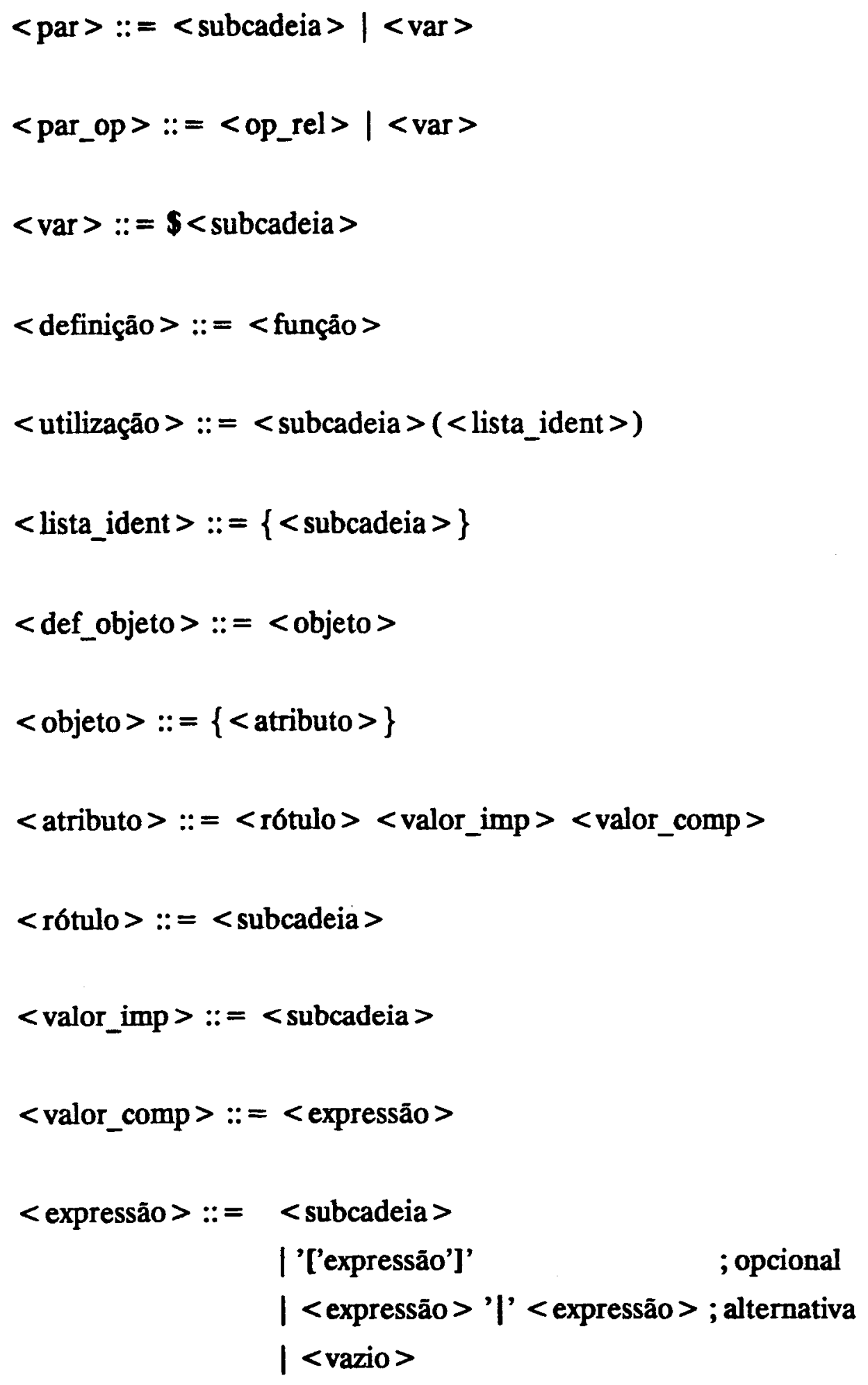

< subcadeia $>::=<$ atributo_alfabeto $>\mid<$ atributo_alfabeto $><$ subcadeia $>$ 


$$
\begin{aligned}
& <\text { atributo_alfabeto }>::=<\text { letra }> \\
& \mid<\text { digito }> \\
& \text { | <atributo_especial > } \\
& \text { | <branco }> \\
& \text { < atributo_especial > ::= * ; "wildcard" de cadeia } \\
& \text { |? ; ;"wildcard" de caractere } \\
& \text { I. } \\
& 1 . \\
& 1= \\
& <\text { par_func_def }>::=<\text { vazio }>\mid\{<\text { subcadeia }>\} \\
& <\text { op_rel }_{\text {_ }}::=\langle|>|<=|>=|<>|= \\
& <\text { letra }>::=\mathbf{A}|\ldots| \mathbf{Z}|\mathbf{a}| \ldots \mid \mathbf{z} \\
& <\text { digito }>::=0|\ldots| 9 \\
& <\text { branco }>::=\text { ', ; caractere branco } \\
& <\text { vazio }>::=" \quad \text {; caractere nulo }
\end{aligned}
$$




\section{Apêndice B}

\section{Lista de Siglas}

ANSI - American National Standards Institute.

ATDM - Multiplexação por Divisão de Tempo Assíncrona.

BNF - "Backus-Naur Form" ou Forma Normal de Backus.

CCITT - Comité Consultatif International de Télégraphique et Téléphonique.

CSMA - Carrier Sense Multiple Access.

CSMA/CD - Carrier Sense Multiple Access with Collision Detection.

DARPA - Defense American Research Project Agency.

DEC - Data Communications Equipment.

DNS - Domain Name System, mecanismo que implementa a hierarquia dos nomes das máquinas na arquitetura Internet.

EBNF - Forma Normal de Backus Estendida.

FDM - Multiplexação por Divisão de Freqüência.

FTP - File Transfer Protocol, protocolo da camada de aplicação da arquitetura Internet.

ICMSC - Instituto de Ciências Matemáticas de São Carlos. 
IEEE - Institute of Electrical and Electronic Engineers.

IFQSC - Instituto de Física e Química de São Carlos.

IP - Internet Protocol, protocolo da camada "internet" na arquitetura Internet.

ISO - International Standards Organization.

ISO/OSI - International Standards Organization / Open Systems Interconnection.

LAN - Local Area Network.

MAC - Medium Access Control, sub-camada de enlace de dados utilizada no padrão IEEE 802.

MAN - Metropolitan Area Network.

MIT - Massachusetts Institute of Technology

NFS - Network File System, sistema gerenciador de arquivos do ambiente SunOS.

NIS - Network Information Service.

NSF - National Science Foundation.

PSN - Protocolo do Serviço de Nomeação.

RFC - Request For Comments, artigos técnicos de domínio público da Internet.

SPP - Servidor de Processamento Paralelo.

STDM - Multiplexação por Divisão de Tempo Síncrona.

TCP - Transmission Control Protocol, protocolo de camada de transporte na arquitetura Internet.

TCP/IP - Transmission Control Protocol / Internet Protocol, conjunto de protocolos Internet.

TDM - Multiplexação por Divisão de Tempo.

WAN - Wide Area Network. 


\section{Apêndice C}

\section{Glossário}

Bridge - ver gateway.

Broadcast - a disseminaçâo simultânea de informaçōes para um conjunto de estaçōes.

Cache - armazenamento intermediário de alta velocidade que é continuamente atualizado através da recepçāo contínua de dados da memória principal. Tem a função básica de reduzir o tempo de acesso.

Caminho - é a seqüência de endereços ou de instruçōes direcionais explícitas, partindo de uma localizaçāo particular até um objeto nomeado. Uma rota ou caminho especifica "como" atingir um lugar particular a partir de outro lugar.

Endereço - Por trás de um nome podem ser escondidos vários níveis de endereçamento, cada um destinado a uma aplicaçāo particular. Normalmente os endereços ficam ocultos aos usuários humanos e nos casos em que é preciso que eles os enxerguem, estes podem ser considerados nomes. Um endereço comunica o sentido de "onde".

Gateway - dispositivo ou conjunto de dispositivos que interconectam duas ou mais redes, possibilitando a transferência de dados entre elas.

Ligação - consiste em associar explicitamente atributos da entidade nomeada com o nome e os armazena em algum registro. Tipicamente, um desses atributos $\varepsilon_{0}$ 
endereço da entidade nomeada.

Nome - identificador usado por humanos para referir-se a objetos que procuram, aos quais desejam ter acesso, ou com os quais desejam comunicar-se. Transmite o sentido sobre "o que" está-se falando. No mundo computacional, os nomes são cadeias de caracteres "ligadas" por algum mecanismo a um objeto particular ou a uma classe de objetos.

Mapear - aplicar uma função com valores em um determinado domínio que retorna seus correspondentes no contra domínio.

Objeto - um recurso logico administrado por uma autoridade.

Resolver um nome - identificar o endereço relacionado ao nome. 